\title{
Hydrogeology of
}

Northwestern Nassau and

Northeastern Queens Courties

Long Island, New York

By WOLFGANG V.SWARZENSKI

GEOLOGICAL SURVEY WATER-SUPPLY PAFER 1657

Prepared in cooperation with the Nassau County Department of Public Works and the Nerw York State Water Resources Commission

With special reference to water in

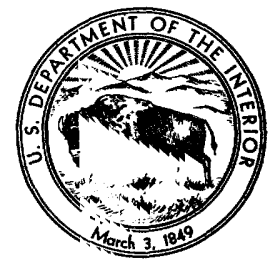

Cretaceous and Pleistocene aquifers 


\title{
UNITED STATES DEPARTMENT OF THE INTERIOR
}

STEWART L. UDALL, Secretary

\section{GEOLOGIGAL SURVEY}

\author{
Thomas B. Nolan, Director
}

The U.S. Geological Survey Library has cataloged this publication as follows:

\section{Swarzenski, Wolfgang Victor, 1917-}

Hydrogeology of northwestern Nassau and northeastern Queens Counties, Long Island, New York. Washington, U.S. Govt. Print. Off., 1963.

88 p., maps, diagrs., tables. and portfolio (maps, diagrs., profile) $24 \mathrm{~cm}$. (U.S. Geological Survey. Water-supply paper 1657)

Prepared in cooperation with the Nassau County Department of Public Works and the New York State Water Resources Commission. Bibliography : p. 62-63.

(Continued on next card)

\section{Swarzenski, Wolfgang Victor, 1917-}

Hydrogeology of northwestern Nassau and northeastern Queens Counties, Long Island, New York. 1963. (Card 2)

1. Geology-Iong Island. 2. Water, Underground-Long Island. 3. Water-supply-Long Island. 4. Borings-Long Island. I. Title. (Series). 


\section{CONTENTS}

Abstract.10
Introduction.
Purpose and scope of investigation
Previous investigations
Acknowledgments
Well-numbering system and map coordinates
Geography
Topography and drainage
Climate
Soils and vegetation
Natural resources
Population and development

Summary of stratigraphy _...

Geologic formations and their water-bearing properties........... 10

Precambrian bedrock ... . . . . . . . . 10

Upper Cretaceous series .

Raritan formation

Lloyd sand member............. 15

Clay member......... 15

Magothy (?) formation........... 16

Pleistocene series

Jameco gravel and undifferentiated deposits of Pleistocene age .........

Gardiners clay

Upper Pleistocene deposits.....

Ronkonkoma drift............ 23

Harbor Hill drift. ... . . . . . .

Age of the upper Pleistocene deposits . .

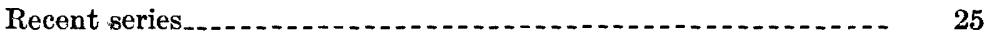

Summary of the geologic history

Hydrology _...

Ground water.......... 28

General features........... 28

Water-bearing units................ 29

Bodies of perched water.......... 29

Shallow unconfined aquifer.

Principal aquifer

Deep confined aquifer............... 32

The water table and piezometric surfaces...

Recharge... 
Hydrology-Continued

Ground water-Continued $\quad$ Page

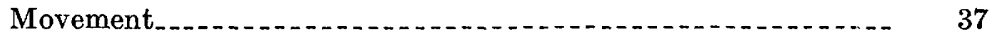

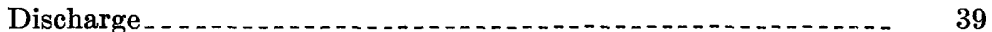

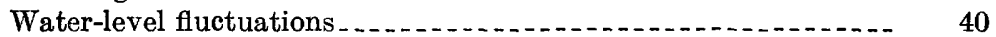

Pumpage...................... 46

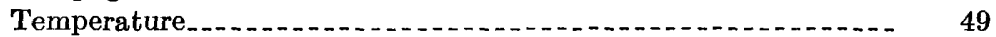

Chemical quality

Contamination...... 51

Surface water

Streamflow characteristics. . . .

Chemical quality and temperature

Utilization of surface water

Summary and conclusions

References cited. 62

Basic data

Index

\section{ILLUSTRATIONS}

[Plates are in separate volume]

Plate 1. Well location map.

2. Bedrock contour map.

3. Contour map of Cretaceous surface.

4. Geologic section $A-A^{\prime}$.

5. Geologic section $B-B^{\prime}$.

6. Geologic section $C-C^{\prime}$.

7. Geologic section $D-D^{\prime}$.

8. Map of surficial deposits.

9. Water-table contour map.

10. Piezometric contour map of principal aquifer.

11. Piezometric contour map of deep confined aquifer.

12. Hydraulic profile $X-X^{\prime}$.

13. Distribution of public supply pumpage.

Figure 1. Index map 4

2. Annual precipitation...

3. Monthly precipitation and temperatures...... 8

4. Section of stratigraphic units........ 11

5. Map showing areas of perched water.... 30

6. Pressure relationships in shallow and deep wells......... 38

7. Hydrograph of four observation wells ...

8. Hydrograph of wells N1119, N2635, and N1479....... 43

9. Daily water-level record, N4266 and N5530_........ 44

10. Hydrograph of well Q470........ 45

11. Map showing distribution of major centers of industrial pumpage. 47

12. Quality-of-water diagram 50

13. Pumpage plot, Port Washington Water District......... 54

14. Location of stream-gaging stations and surface-water sampling points. 


\section{TABLES}

TABLE 1. Population data, Nassau County, N.Y., 1900-57

Page

2. Summary of stratigraphy and water-bearing propertiss of the deposits underlying northwestern Nassau and northeastern Queens Counties, N.Y.

3. Estimated permeabilities of materials in Lloyd sand mamber of Raritan formation

4. Estimated permeabilities of materials in Magothy(?) formation . .

5. Estimated permeabilities of Jameco gravel and urdifferentiated Pliestocene valley fill

6. Geologic correlation of strata in some wells in northwestern Nassau County, N.Y.

7. Ground-water pumpage for public water supply in northwestern Nassau County, N.Y. $(1930,1940,1950,1956,1957)$.

8. Stream-discharge measurements in northwestern Nassau

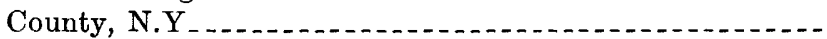

9. Chemical analyses of waters from Long Island Sound and Atlantic Ocean

10. Chloride analyses of surface water in northwesterr Nassau Clounty, N.Y

11. Records of selected wells in northwestern Nassau ard northeastern Queens Counties, N.Y

12. Logs of selected wells in northwestern Nassau ant northeastern Queens Counties, N.Y

13. Water-level measurements in selected wells in northwestern Nassau and northeastern Queens Counties, N.Y

14. Chemical analyses of ground water in northwesterr Nassau and northeastern Queens Counties, N.Y

15. Chloride analyses of water from selected wells in northwestern Nassau County, N.Y . . . . . . . . . 


\title{
HYDROGEOLOGY OF NORTHWESTERN NASSAU AND NORTHEASTERN QUEENS COUNTIES, LONG ISLAND, NEW YORK
}

\author{
By Wolfgang V. Swarzenski
}

\begin{abstract}
A detailed investigation of the geology and ground-water occurrence in northwestern Nassau and northeastern Queens Counties, N.Y., has been completed by the U.S. Geological Survey, in cooperation with the Nassau Co'nnty Department of Public Works and the New York State Water Resources Commission. The area, about 63 square miles, includes the peninsulas of Gre?.t Neck and Manhasset Neck and the western part of Nassau County as far south as Garden City. Unconsolidated sediments of Pleistocene and Cretaceous ag?, 200 to 800 feet thick, constitute the ground-water reservoir of the area. The reservoir includes three discrete aquifers, not all found in the same locality, which iransect geologic boundaries. The shallow unconfined aquifer consists of those permeable Pleistocene and Cretaceous deposits that lie within the upper part of the zone of saturation, which extends from slightly below sea level to more than 110 feet above sea level. It is an abundant source of water in much of the area, particularly in the southern part, where the aquifer consists of coarse sand and gravel in a glacial-outwash plain. The intermediate or principal aquifer consists largely of that part of the Magothy(?) formation that occurs from about 50 feet below sea level downward to the top of the clay member of the Raritan formation. Locally, however, the aquifer includes Pleistocene deposits whicl blanket the Magothy(?) formation or lie in channels cut into it. Although the principal aquifer has limited extent to the north, it is the chief source of water in most of the area, except the peninsulas. The lower or deep confined aquifer is found beneath the entire project area, and consists of the Lloyd sand ramber of the Raritan formation and the hydraulically contiguous Jameco gravel. The lower limit of the aquifer is the bedrock surface; its upper limit is defined by the overlying clay member of the Raritan formation and the Gardiners c'ay, the latter abutting against the clay member on the north or, in some valleys and embayments, lying directly upon the clay member. Thus, hydraulic continuity exists between the Lloyd sand member of the Raritan formation (Cretaceous) and the Jameco gravel (Pleistocene) in the northern part of Manhasset and Great Necks. The two contiguous clay bodies overlying the aquifer, the clay member of the Raritan formation and the Gardiners clay, form an effective confining bed which probably extends beyond the shore lines of the project area. The deep confined aquifer is particularly important on Manhasset and Great Necks where locally it is the only source of water available for large public-supply or industrial needs.

In general, ground-water supplies in sufficient quantity and of excellent quality can be obtained from the three aquifers underlying northwester Nassau and northeastern Queens Counties, N.Y. Ground-water withdrawals for public
\end{abstract}


supply have increased with population growth and expanded use from an average of about 10 millions of gallons per day in 1940 to $30 \mathrm{mgd}$ in 1957 . In addition, about $10 \mathrm{mgd}$ are pumped for various industrial, institutional and private uses. Much of the water pumped by industry is returned to the ground by diffusion wells and recharge basins. However, an increasing amount of water is lost from the ground-water reservoir due to the expanding network of server systems discharging directly to the sea.

In the Manhasset Neck and Great Neck areas, ground-water resources are approaching full development in terms of the total available suprly, if such development has not been reached already (1959). The chief limitir $g$ factor to further expansion lies in the geometry of the aquifers and the reduce thickness of permeable saturated sediments. In the northern part of both peninsulas, the ground-water reservoir is only about 200 to 400 feet thick, and, locally, as much as 75 percent of the strata in the reservoir consists of rather impermeable silt and clay of the Raritan formation or the Gardiners clay. In these areas, substantial quantities of water can be obtained only from the deep confined aquifer. Inasmuch as many of the wells screened in this aquifer are in nearshore zones, increased withdrawals from this source might result ir sea-water encroachment. Excessive pumping has caused sea-water encroachment in the vicinity of one pumping installation in Port Washington; in other shore zones, encroachment may be impending, as indicated by abnormally high chloride concentrations in some wells during periods of increased pumping.

The eastern and southeastern parts of the project area, where maximum natural recharge occurs, offer the greatest potential for future increased withdrawals. In an area circumscribed by the 60 -foot contour of the water table, including the ground-water divide, no significant changes in ground-water storage, other than those attributable to precipitation patterns or temporary local pumping, have occurred since 1903. A small increase of withdrawals in this area probably would not alter the position of the water table appreciably. Moreorer, within limits not yet preseribed, additional withdrawals would increase gradients and induce greater ground-water flow from adjacent, virtually untapped sources to the east of the project area without detrimental effects to the ground-water reservoir. Much of the ground water in the principal aquifer reaches Manhasset and Great Necks by underflow from the south. Some increase in withdrawals from the principal aquifer in the southern part of the penirsulas also would steepen northward gradients from the main ground-water divide, induce greater flow, and intercept some of the ground water now discharging laterally into the bays.

As annual ground-water withdrawals in the project area approach the total available supply, the need will increase for more detailed evaluation of all factors that might affect the selection of future well sites and permissible rates of groundwater withdrawal. Of particular importance will be the continuatior of monitoring programs for water levels, chemical quality, and temperature and revision and expansion of the program in the future to conform to changing withdrawal patterns in the various aquifers.

\section{INTRODUCTION}

\section{PURPOSE AND SCOPE OF INVESTIGATION}

A detailed areal investigation of the geology and ground-water resources of northwestern Nassau and northeastern Queens Counties, N.Y., has been completed by the U.S. Geological Survey, in coopera- 
tion with the Nassau County Department of Public Worl's and the New York State Water Resources Commission. The present report, including an area of rapid population and industrial grovth during the past two decades, is a contribution toward the continuing cooperative program for the collection and interpretation of data concerning the ground-water resources of Long Island. Detailed geologic information and a thorough understanding of hydrologic principles are essential to orderly development and management of ground-water resources. Nassau County depends exclusively on ground water to fill the extensive and increasing water requirements of its municipalities and industries.

The present report is based on fieldwork by the auther between 1955 and 1957, including mapping of the surficial deposits, collection of subsurface geologic data, correlation of rock samples with stratigraphic units elsewhere on Long Island, a study of the relation between geology and ground-water hydrology, and analysis of data gathered in a program of systematic water-level measurements. Two observation wells were drilled to bedrock, in Great Neck and Sands Point, respectively. The Geological Survey also installed 16 shallow water-tableobservation wells in the project area. During 1956 and 1957 John Isbister assisted in the collection of hydrologic data.

The investigation was under the direct supervision of J. E. Upson and George C. Taylor, Jr., successive district geologists of th e Mineola district.

\section{IOCATION AND EXTENT OF AREA}

The area of investigation (fig. 1), hereafter called the project area, comprises about 63 square miles on western Long Island, N.Y. bordered on the north by Long Island Sound and lying botween lat $40^{\circ} 43^{\prime} 33^{\prime \prime}$ to $40^{\circ} 54^{\prime} 13^{\prime \prime} \mathrm{N}$. and long $73^{\circ} 37^{\prime} 30^{\prime \prime}$ to $73^{\circ} 46^{\prime} 18^{\prime \prime} \mathrm{W}$. About 52 square miles of the land area is in Nassau Courty and 11 square miles is in Queens County, a borough of the City of IJew York. U.S. Geological Survey quadrangle maps for the area are available at a scale of 1:24,000; contour intervals are 10 and 20 feet. The map area is included in the Sea Cliff, N.Y. quadrangle sheet and small sections of adjacent sheets.

\section{PREVIOUS INVESTIGATIONS}

The physiography and geology of Long Island have beer described in detail by Fuller (1914). A. C. Veatch and others (1906) assembled geologic information, water-level records and chemical analyses in an early study of Long Island's ground-water resources. These and other reports on the geology and ground-water resources of Long Island encompass larger areas but contain data pertinent to the present investigation. A contour map of the bedrock surface in western Long 


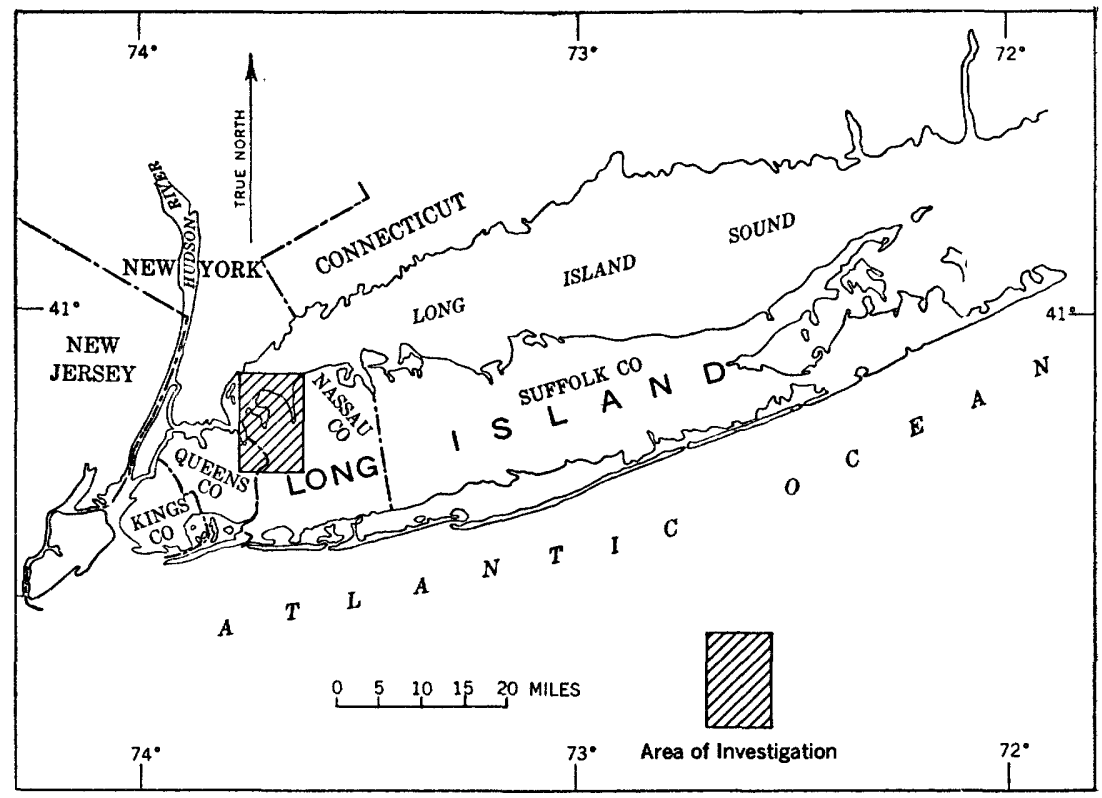

FiguRe 1.-Map of Long Island, N.Y., showing area of investigation.

Island was prepared by deLaguna and Brashears (1948). Records of wells, geologic-correlation tables, and data on ground-water withdrawals have been published in many of the bulletins of the I'ew York State Water Power and Control Commission. (See "Keferences cited.") Recent test drilling in southwestern Nassau County has yielded stratigraphic and lithologic information (Perlmutter and others, 1959), which also is applicable to the present rerort area, adjoining to the north. J. F. Hoffman and E. R. Lubke (written communication, 1959) have compiled chloride concentrations and ground-water temperatures for wells in Nassau County. U.S. Geological Survey Water-Supply Papers, containing water-level measurements and related hydrologic data for many of the observation wells, are listed in a report by Isbister (1959, table 3$)$.

\section{ACKNOWLEDGMENTS}

The writer wishes to express his appreciation to the generous assistance of well drillers and Water District superintendents in furnishing field data for this report. Records of test borings, water-level data and chemical analyses were made available by officials of the Nassau County Department of Public Works, Department of Health, and agencies of the State of New York. The writer is particularly indebted to W. Fred Welsch, Senior Engineer, Nassau County Depart- 
ment of Public Works, and Arthur H. Johnson, Associate Hydraulic Engineer, New York State Water Resources Commission (formerly New York State Water Power and Control Commission), for their generous and continued support of the investigation. The present report includes data collected by U.S. Geological Survey personnel and cooperating agencies during the course of many years. Published and unpublished information was used freely in an effort to solve the complex geologic and hydrologic problems of the report area. The work of earlier investigators is acknowledged.

\section{WELL-NOMBERING SYSTEM AND MAP COORDI ${ }^{\top}$ ATES}

Well numbers on Long Island are assigned in sequence by the New York State Water Resources Commission as information is obtained and have no bearing on location. The well numbers are preceded by a letter designating the county in which the well is located; thus, Q1293 refers to a well in Queens County, whereas N1293 is in Nassau County. As an aid in locating wells, the map area (well-location map, pl. 1) has been subdivided into $21 / 2$-minute rectangles, which are designated by number and letter in the indexed margins. The coordinstes, given in all major tables of the report, designate the rectangle in which the well is located and indicate distances of the well in miles, first, north, then west, from the southeast corner of that rectangle. Geologic and hydrologic data for wells shown on plate 1, but not published in this report, are available for consultation in the files of the Geological Survey office at Mineola, N.Y.

\section{GEOGRAPHY}

\section{TOPOGRAPHY AND DRAINAGE}

Long Island lies entirely within the Coastal Plain province of the northeastern United States. The area of investigation, on western Long Island, may be subdivided into three morphologic units; from north to south (1) the headlands, including Great Neck and Manhasset Neck, (2) the Harbor Hill terminal moraine, and $(\curvearrowleft)$ the glacialoutwash plain. (See pl. 8.) The headlands rise abrupt] 7 from Long Island Sound and its bays to rather uniform altitudes of $\varepsilon ?$ to 100 feet near their northern tips. Southward, the headlands, which are mantled thinly by glacial till, become increasingly irregular, being dissected by small streams discharging into the bays, to the erst and west. Individual hills rise to altitudes above 200 feet. Within the project area, the headlands are indented by three major bays. Hempstead Harbor, Manhasset Bay, and Little Neck Bay. These bays have a general north-south orientation and are 3 to 5 miles in length. The Harbor Hill terminal moraine, consisting of a series of coalescing irregular hills, forms a pronounced ridge, trending to the northeast, 
that rises 80 to 150 feet above the headlands. The highest altitudes in western Long Island are along this ridge, Harbor Hill itself riving to 368 feet above sea level. The glacial outwash plain of sand and gravel abuts the moraine and slopes southward from an altitude of about 140 feet at the southern edge of the moraine to about 80 feet in Garden City; thence, its gentle southward slope is continued to the shore areas of southern Nassau County at gradients of about 20 feet per mile.

There are no large streams in the area. Small streams, sustained by local ground-water discharge, flow predominantly to the north and west at average rates of 0.25 to $3.0 \mathrm{cfs}$ (cubic feet per second). An exception is Cedar Swanp Creek, which flows into Hempstead Harbor near Glen Cove at average discharge rates of more than $7 \mathrm{cfs}$. Most of its drainage area, however, lies beyond the eastern limit of the area. Nearly all streams are small in relation to the valleys they occupy. The oversized valleys originated in Pleistocene time, when continental ice masses and associated melt water modified the pattern of streamflow into the Atlantic Ocean and the depression of Long Island Sound.

\section{CIIMATE}

The climate of Long Island, in contrast to other localities within the State of New York, is tempered by its low altitudes and proximity to the ocean. Precipitation is distributed fairly evenly throughout the year, amounting to an annual average of 44.20 inches for 1938-39 to 1957-58 at Mineola, in Nassau County. At that station, a low of 32.60 inches was reported for $1946-47$, whereas in $1957-58$ a high of 57.64 inches was recorded. Local variations in precipitation are shown in figure 2 , in which annual precipitation at two stations in Nassau County (Manhasset and Mineola, N.Y.) is compared with records for New York City, for the period 1938-39 to 1957-58. Annual precipitation rates shown in the diagram are computed for the water year, October 1 to September 30 .

Figure 3 shows monthly average precipitation and temperatures at The Battery, New York City, N.Y., based on long term records by the U.S. Weather Bureau. Precipitation reaches a maximum during August at The Battery and also in Nassau County. Monthly average precipitation ranges from 3 to more than $4 \frac{1}{2}$ inches at most stations in Nassau County.

The annual average temperature in New York City is $52.7^{\circ} \mathrm{F}(1872-$ 1957, U.S. Weather Bureau). Average temperatures for January and July are $31.8^{\circ} \mathrm{F}$ and $74.6^{\circ} \mathrm{F}$, respectively. (See fig. 3.) In New York City and on Long Island temperatures are rarely below $0^{\circ}$ or higher than $95^{\circ} \mathrm{F}$. The frost-free season has an average length of about 190 days, the average date of the last and first killing frost being 
April 22 and October 28, respectively, at Roslyn (Lounsbury and others, 1928, p. 5). The same authors report annual average temperatures at $51^{\circ} \mathrm{F}$ at Roslyn and Farmingdale, in Nassau County.

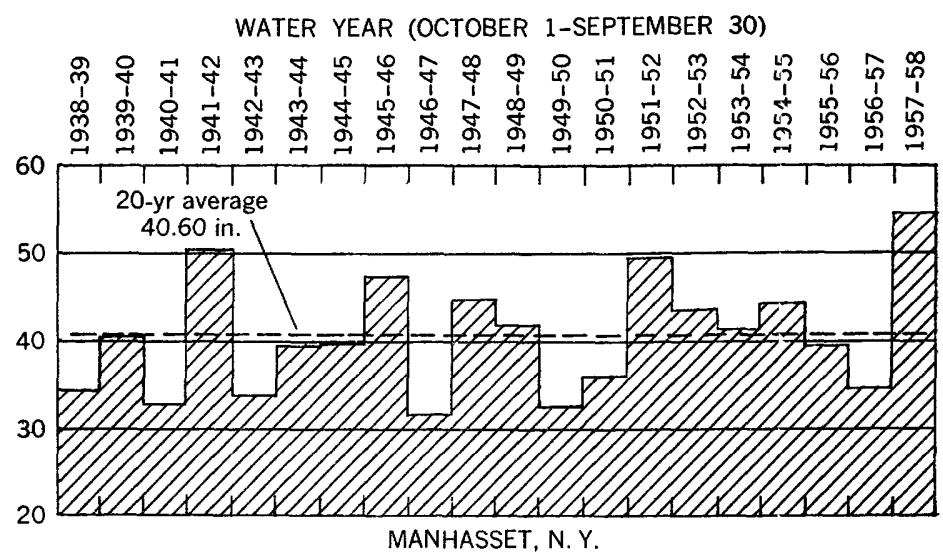

(From records of Nassau County Department of Public Horks)

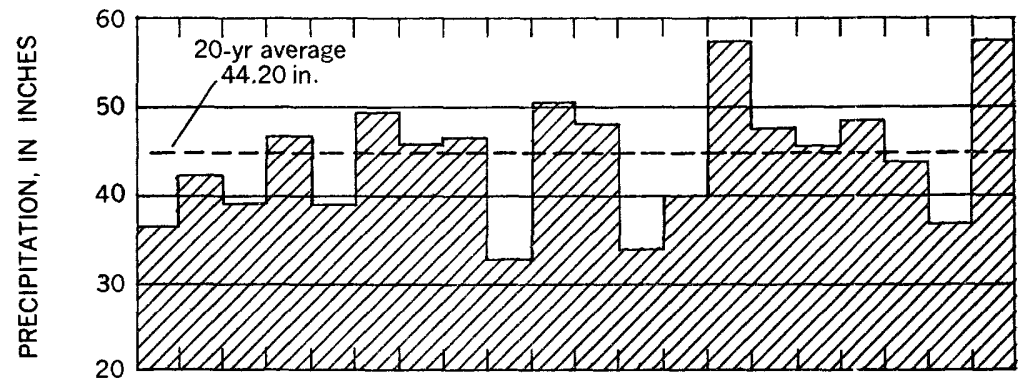

MINEOLA, N. Y.

(From records of Nassau County Department of Public Works)

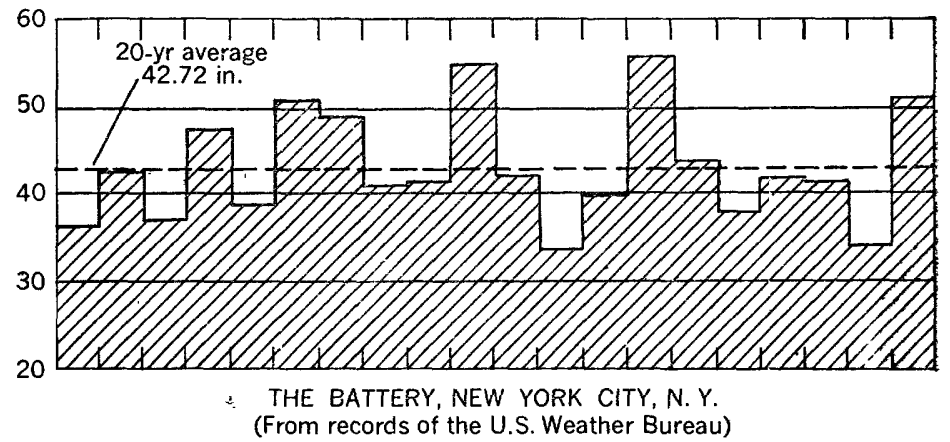

Figure 2.-Annual precipitation at Manhasset, Mineola, and New York City, N.Y. (1938-39 to 1957-58). 


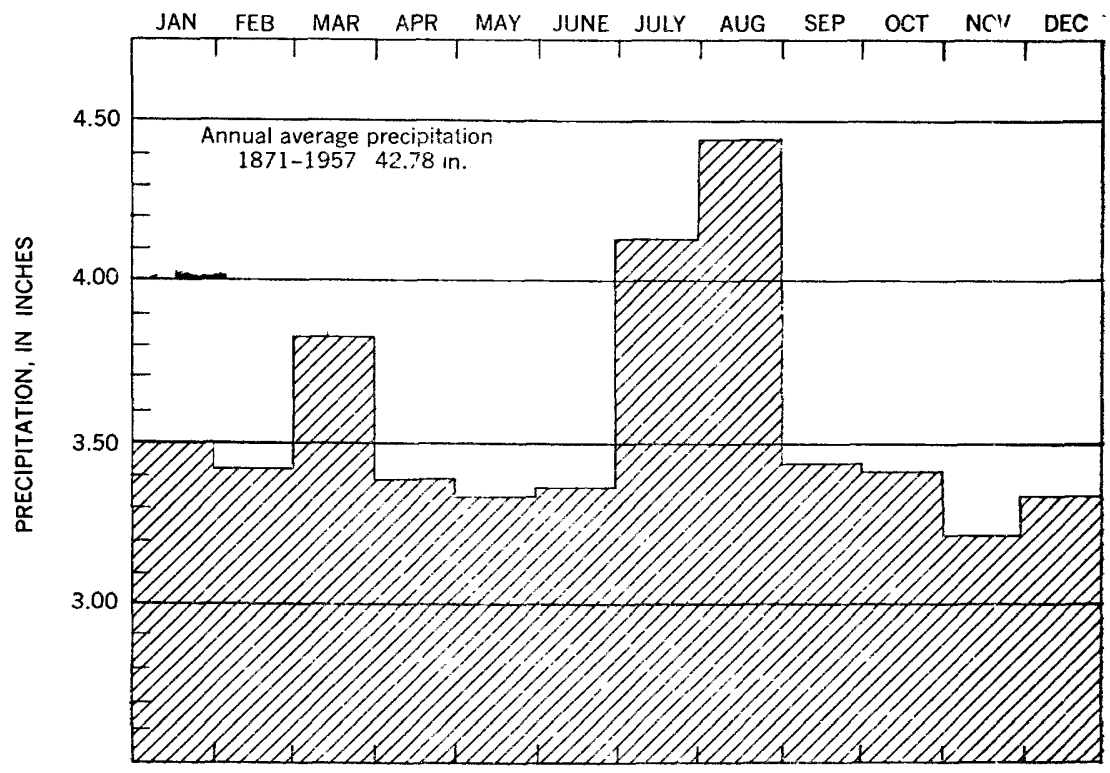

Monthly average precipitation (1871-1957) at the Battery, New York City, $\mathrm{N}$ Y.

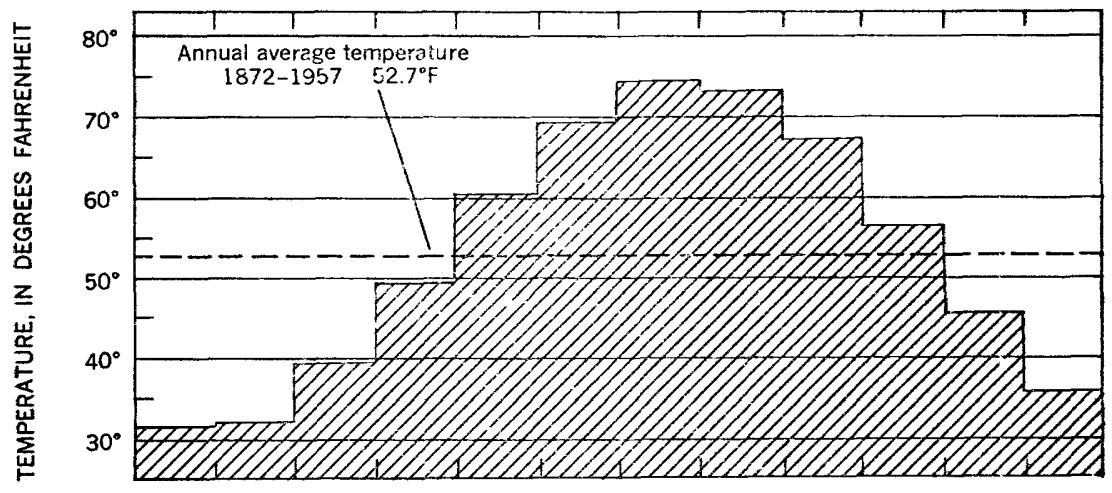

Monthly average temperature (1872-1957) at the Battery, New York City, N. Y.

Frauge 3.-Monthly precipitation and temperatures at The Battery, New York City, N.Y.

\section{SOILS AND VEGETATION}

The soils of Nassau and Suffolk Counties, N.Y. have been mapped and described by Lounsbury and others (1928). In most of northwestern Nassau County, the soils have a silty- and sandy-loam texture, are developed to a depth of 2-3 feet, and are usually yellowish brown. A typical soil profile includes a mat of vegetative debris overlying 6 to 
8 inches of top soil that is rich in organic material derived from the original plant cover of the area. The more moisture-retentive soils of the north shore and on the terminal moraines generally support forest vegetation, whereas the soils in the southern part of the area support a grass cover. In the latter category are the dart brownishblack soils of the Mineola-New Hyde Park area; these represent a unique occurrence of well-drained, dark-colored soil east of the Appalachian Mountains (Lounsbury, 1928, p. 21). Lonal areas of beach and dune sand, peat deposits and tidal marshes are found along the shoreline.

Drainage is highly variable, depending on the clay content of the soil and the nature of the subsoil material, which ranges from compact clayey till to outwash gravel. The soils, which are generally acid, are adaptable to agricultural use in areas of suitable slope snd drainage

\section{NATURAL RESOURCES}

Abundant ground-water supplies and fertile soils are the chief natural resources of Nassau County. Extensive sanc and gravel deposits of Pleistocene age furnish material for building and road construction, supplying not only local needs but also, in part, those of the New York metropolitan area. None of the few deposits of brick clay in northwestern Nassau County are being exploited o.t the present (1959) time.

\section{POPULATION AND DEVELOPMENT}

The area of Nassau County, settled in early colonial times, was part of Queens County until 1899. At that time, with the establishment of Greater New York, Nassau County was separated from Queens, and Mineola became the county seat. The area consisted largely of rural and residential districts until compars.tively recent times. The county experienced a spectacular population increase during and after World War II, as shown in table 1.

Table 1.-Population data, Nassau County, N.Y., 190门-57

[From U.S. Burean of Census]

\begin{tabular}{|c|c|c|c|}
\hline Year & Population & Year & Population \\
\hline $\begin{array}{l}1900 \\
1910 \\
1920 \\
1930\end{array}$ & $\begin{array}{r}55,448 \\
83,930 \\
126,120 \\
303,053\end{array}$ & $\begin{array}{l}1940 \\
1950 \\
1957\end{array}$ & $\begin{array}{r}406,748 \\
672,765 \\
1,178,075\end{array}$ \\
\hline
\end{tabular}

The estimated population of northeastern Nassau County in 1959 was about 200,000 . Many of the villages have large residential sections. The large population influx after 1940 was due partly to 
the establishment of many new industries in the area. L:versified light manufacturing, often of a highly specialized type, is concentrated in the central part of Nassau County; some industries are located along the north shore which, however, is still predominantly an area of residential development and country estates. Truck farming, formerly of some economic importance, had all but disappeared from northwestern Nassau County in 1959.

\section{GEOLOGY}

\section{SUMMARY OF STRATIGRAPHY}

On Long Island and in the project area, unconsolidated sediments: of Quaternary and Cretaceous age rest on a crystalline bedrock surface that slopes to the southeast. These units are shown diagrammatically in figure 4. The bedrock probably is of Precamk wian age. The Late Cretaceous deposits, mostly of terrestrial origin, are the Raritan and Magothy(?) formations. Pleistocene deposits of preWisconsin age are the Jameco gravel and Gardiners clay, botl of small extent in the project area. The bulk of the Pleistocene deposits are till and outwash sequences associated with two ice advances within the Wisconsin stage. Shoreline, swamp, and alluvial deposits of Recent age locally mantle the older deposits.

The unconsolidated sediments, saturated with water from the weathered bedrock upward to the water table, yield water to wells screened in the more permeable zones. The water-bearing characteristics of geologic formations in northwestern Nassau County and northeasthern Queens County are summarized in table 2. Jugs and geologic correlations for selected wells and test borings are given in table 12 .

\section{GEOLOGIC FORMATIONS AND THEIR WATER-BEARING PROPERTIES}

PRECAMBRIAN BEDROCK

Bedrock occurs at depths ranging from about 200 to 800 feet below sea level. Descriptions of cores from wells indicate that it is generally a biotite schist or gneiss, which may be intruded by granite or pegmatite. In most places the bedrock is strongly weather $3 d$ in its upper part, the weathered zone being several tens of feet thick. Well N4266, in Great Neck, penetrated 71 feet of weathered bedrosk without reaching fresh rock. (See log N4266, table 12.) Weathe"ed bedrock may consist largely of textureless residual clay, with interspersed mineral grains, and may thus be mistaken for a clay stratum.

The configuration of the crystalline bedrock surface is important in that it defines, for practical purposes, the lower limit of the groundwater reservoir on Long Island. Contours drawn on the buried 


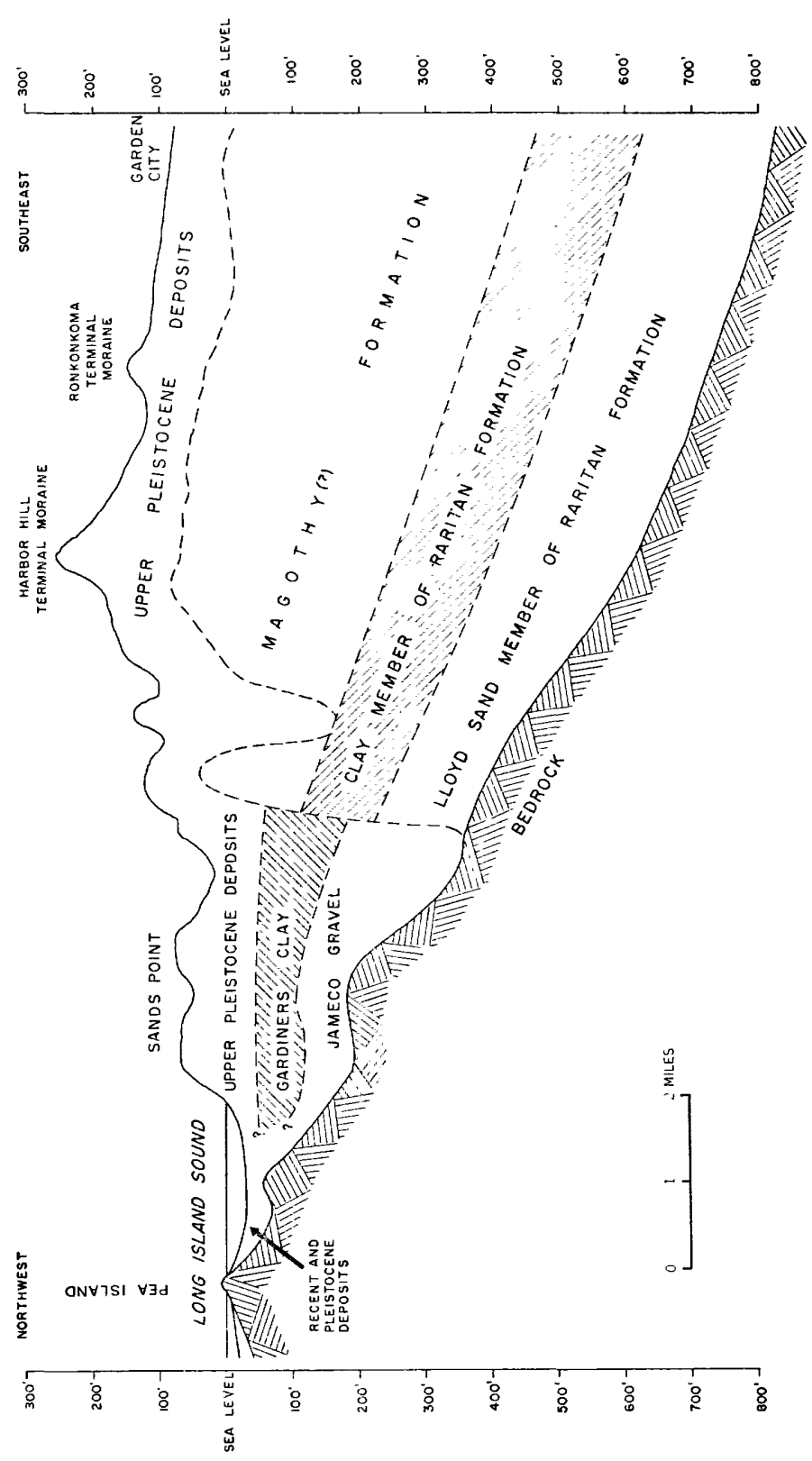

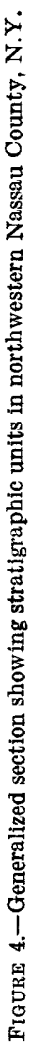




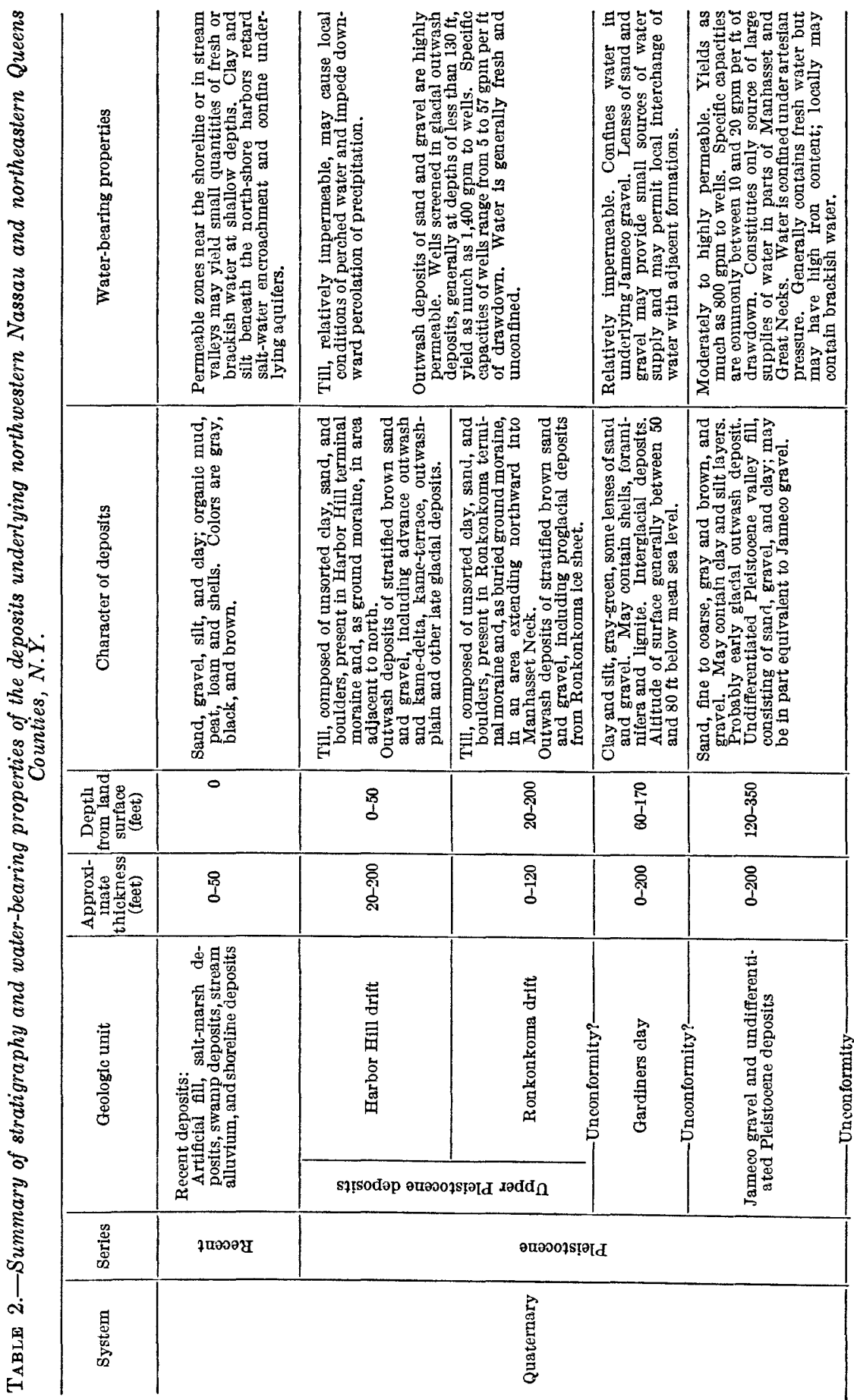




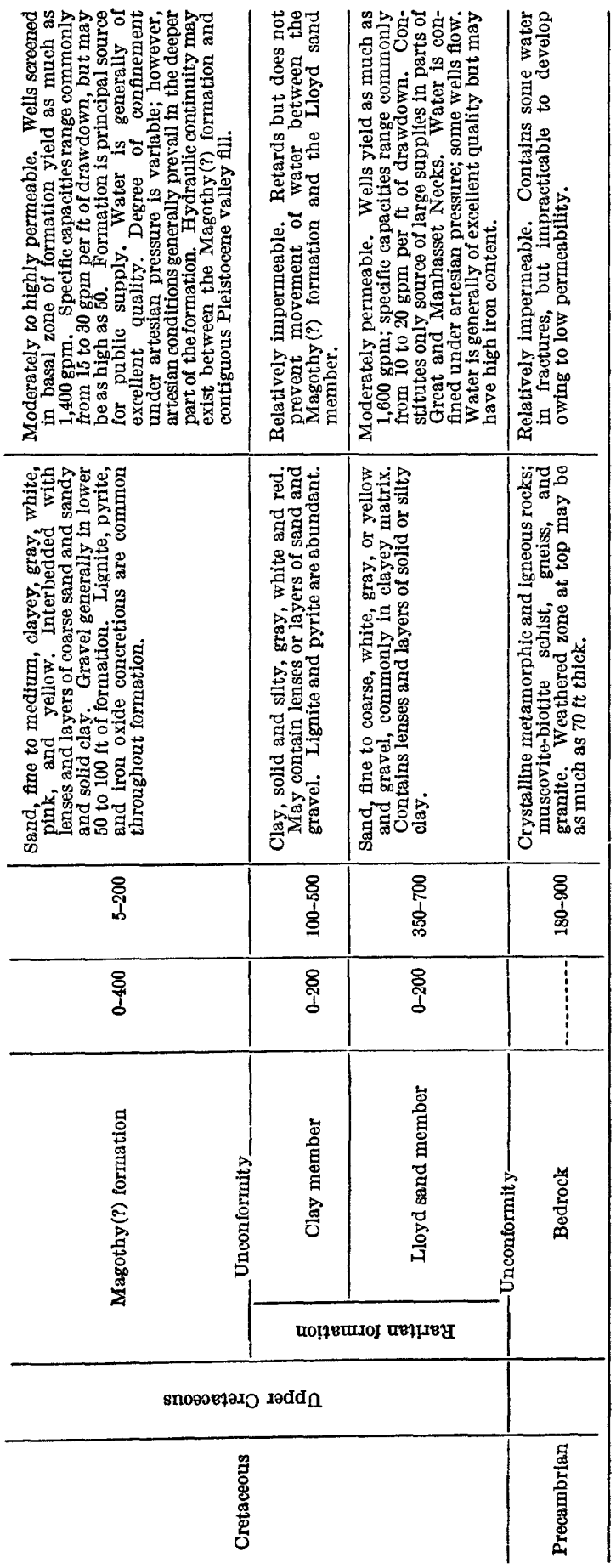


bedrock surface (pl. 2) show the general southeasterly slope of the basement rocks at about 50 feet per mile. However, there are indications that this regional slope is reversed locally in the northern part of Manhasset and Great Necks. For example, well data indicate a leveling or a reversal of bedrock slope in Sands Point, Port Washington, and Kings Point. (See also geologic sections shown on pls. 4-6.) Channel cutting to a depth slightly greater than 350 feet below present sea level seems to have occurred during a pre-Wiscnnsin stage of the Pleistocene when sea level was perhaps 400 feet lover than at present. Erosion at that time appears to have removed the bulk of Cretaceous deposits in the northernmost areas of Great Neck and Manhasset Neck. Undoubtedly there are other variations in the relief of the bedrock surface, which might be revealed by exploratory drilling. In a seismic study of the Long Island area, Oliver and Drake (1951) found indications of relief of about 200 to 300 feet on the crystalline rock surface.

Although small quantities of water are obtained from bedrock wells in the extreme western part of Long Island, no ground-wrater withdrawals by bedrock wells are made in the project area.

\section{UPPER CRETACEOUS SERIES}

Deposits of Late Cretaceous age on Long Island lie unccnformably above bedrock and consist of interbedded sand, gravel, silt, and clay which are dominantly of terrestrial origin. Two formations are recognized: the older Raritan formation, which is divided into the Lloyd sand member below and the clay member above, and the younger Magothy(?) formation. The Raritan formation, $1 \mathrm{y}$ correlation with New Jersey formations, has been referred to the basal part of the Upper Cretaceous series. The term Magothy(?) formation, used to designate all Cretaceous strata on Long Island that lie above the Raritan formation, probably includes an equivalont of the Magothy formation of New Jersey and also some Upper Cretaceous strata younger than the Magothy of New Jersey (Perlmutter and Crandell, 1959, p. 1066).

The Cretaceous deposits, sloping to the southeast, are known almost entirely from well logs. They attain their greatest thickness in the vicinity of Garden City. Here the Creatceous, beginning at about sea level and extending to 800 feet below, is divided almost equally between the Raritan and Magothy(?) formations. The distribution of Cretaceous deposits is shown by a contour map on the buried Cretaceous surface (pl. 3) and geologic sections (pls. 4-7). The location of geologic sections and Cretaceous outcrops are shown in plate 8 . 
The Lloyd sand member of the Raritan formation, lying on bedrock, is about 150 to 200 feet thick. The top of the Llord ranges in depth from about 250 feet below sea level in the center of Manhasset and Great Necks to about 600 feet below sea level in the southeastern part of the project area. The Lloyd sand member is composed of white, yellow, or gray sand and gravel, which in many places has a clayey matrix. The coarse fraction consists entirely of quartz and chert fragments, which are subangular to subrounded, and a small percentage of stable accessory minerals. Although lense of clay and clayey sand are fairly common, the Lloyd sand member is a relatively permeable artesian aquifer in almost the entirs project area. It is absent in Manhasset and Great Necks, where it has been replaced by the Jameco gravel which is hydraulically connected with the Lloyd sand member to the south. These contiguous formations constitute the deep confined aquifer which is discussec beyond. Wells screened in the Lloyd sand member yield as much as 1,600 gpm (gallons per minute). Specific capacities range commonly from 10 to $20 \mathrm{gpm}$ per foot of drawdown. Theis and others (1954) developed a method of estimating permeability from specific capacity. By application of this method, permeabilities (See Wenzel and Fishel, 1942 , p. 7 for definition of coefficient of permeability) for the Lloyd sand member were obtained, as shown in table 3 .

TABLE 3.-Estimated permeabilities of materials in Lloyd sand member of Raritan formation

\begin{tabular}{r|r|r|r|r}
\hline Well & $\begin{array}{c}\text { Screened zone } \\
\text { (feet below land } \\
\text { surface) }\end{array}$ & $\begin{array}{c}\text { Specific } \\
\text { capacity } \\
\text { (gpm per ft) }\end{array}$ & $\begin{array}{c}\text { Approx. } \\
\text { aquifer } \\
\text { thickness } \\
\text { (feet) }\end{array}$ & $\begin{array}{c}\text { Estimated } \\
\text { permea- } \\
\text { bility } \\
\text { (gpd per sq ft) }\end{array}$ \\
\hline & $404-434$ & 10 & 140 & 200 \\
& $360-428$ & 16 & 150 & 270 \\
23 & $376-401$ & 5 & 40 & 300 \\
1715 & 26 & 210 & 330 \\
1802 & 21 & 150 & 380 \\
1958 & 11 & 140 & 210 \\
\hline
\end{tabular}

CLAT MEMBER

The clay member of the Raritan formation, lying above and confining the Lloyd sand member, is the chief aquiclude o." confining bed within the ground-water reservoir of the project area. It consists of about 100 to 200 feet of relatively impermeable solid and silty clay, usually dark gray, and lignitic zones. Colors are variable and 
include red, white, and variegated. Gravelly strata and calcareous concretionary zones also have been reported. The top of the clay member is about 100 to 150 feet below sea level in the northern peninsulas, and the clay member slopes to the southeast at a rate similar to that of the bedrock surface. The northern limit of the clay member coincides with the boundaries of the Cretaceous deporits shown in plate 3. Locally, at depths of less than 100 feet below sea level, parts of the clay member apparently were deformed and dirnlaced by Pleistocene ice, and their stratigraphic position is doubtful. Stratigraphic correlation is further complicated by the fact that clay strata of similar lithology, for which no identifying criteria have been found, occur in both the Raritan and Magothy (?) formations. Facies changes within the clay member of the Raritan formation are indicated in two areas, particularly along the shores of Hempstead Farbor and in Port Washington, where silt and clayey sand, rather than solid clay, are dominant. Columnar plots for wells N6346, I'662, and N2002, along Hempstead Harbor, are shown on geologic section $D-D^{\prime}$, plate 7. In Port Washington, toward its northern limit, the clay member consists of about 30 feet of solid clay at the top, which is underlain by clayey sand and sand. There is no marked change in lithology as the underlying Lloyd sand member is penetrated. (See columnar plot and electric $\log$ of well N5530, pl. 5, and test boring N6089T, pl. 6).

\section{MAGOTHY(?) FORMATION}

The Magothy(?) formation is slightly more than 400 feet thick at the maximum; its upper surface is more than 100 feet above sea level locally in Port Washington and Manhasset. The formaticn consists chiefly of fine micaceous sand, sandy clay, and clay. The colors are usually gray, white, pink, or red; lignite, pyrite, and iron oxide concretions are common throughout. Gravel occurs in a zone near the bottom and in lenses at somewhat higher altitudes. As in the Lloyd sand member, the sand and gravel of the Magothy(?) consist essentially of quartz and chert and small amounts of stable heavy and opaque minerals. Common accessory minerals include garnet, tourmaline, zircon, rutile, and kyanite. Although the Magothy(?) formation is characteristically lenticular and may locally consist almost entirely of fine clayey sand and silt, its more permeable zones yield by far the greatest share of the water pumped in the project areq. Many of the larger wells screened in the basal part of the formation are pumped at rates of 1,000 to $1,400 \mathrm{gpm}$; specific capacities commonly range from 15 to 30 , but may be as high as 50. Estimated pormeabilities of materials from the Magothy(?) formation, computed from specific capacities of wells, range from 270 to $870 \mathrm{gpd}$ (gallons per day) per square foot as shown in table 4 . 
TABLE 4.-Estimated permeabilities of materials in Magothy(?) fcrmation

\begin{tabular}{|c|c|c|c|c|}
\hline Well & $\begin{array}{l}\text { Screened zone } \\
\text { (feet below } \\
\text { land surface) }\end{array}$ & $\begin{array}{c}\text { Specific } \\
\text { capacity } \\
\text { (gpm per ft) }\end{array}$ & $\begin{array}{l}\text { Approx. aqui. } \\
\text { fer thickness } \\
\text { (feet) }\end{array}$ & $\begin{array}{c}\text { Estimated } \\
\text { permeability } \\
\text { (gpd per sq ft) }\end{array}$ \\
\hline 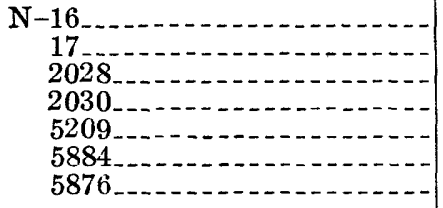 & $\begin{array}{r}378-438 \\
405-465 \\
425-485 \\
190-215 \\
260-300 \\
92-163 \\
168-238\end{array}$ & $\begin{array}{l}19 \\
11 \\
28 \\
14 \\
20 \\
37 \\
11\end{array}$ & $\begin{array}{r}150 \\
80 \\
190 \\
80 \\
100 \\
110 \\
110\end{array}$ & $\begin{array}{l}280 \\
350 \\
400 \\
440 \\
540 \\
870 \\
270\end{array}$ \\
\hline
\end{tabular}

The stratigraphic position of the Magothy(?) is shovn on four geologic sections (pls. 4-7). The areal extent and relief of the eroded and buried Cretaceous surface is shown by a contour map (pl. 3). Generally the contours are drawn on the Magothy(?) surface except in some major valleys where the formation may be absent entirely. In this case, the contours represent the top of the eroded Raritan formation, most commonly the clay member. Cretaceous deposits underlie almost the entire area, except in the northern tips of Manhasset and Great Necks. In Kings Point and Sands Point the northern limit of the Cretaceous is marked by a buried cuesta apparently formed in the clay member of the Raritan formation at or belov sea level. Quite possibly this cuesta originated as the obsequent north-facing slope of a strike valley cut to or nearly to bedrock in Tertiary time. Erosion in early Pleistocene time probably removed all Cretaceous sediments in the northern part of the peninsulas, leaving isolated remnants to the east and west and probably in the wider parts of Long Island Sound.

The relief of the Cretaceous surface, moderate in the sc'ithern part of the area but more pronounced in the north, was created by postCretaceous consequent streams draining toward the Atlentic Ocean. Obsequent streams flowing into the strike valley now fo"ming Long Island Sound were responsible for the initail relief in the Cretaceous surface along the north shore. The present north-shore bays and harbors presumably owe their origin to obsequent streams. Pleistocene erosion seems to have been a strong contributirg factor in producing more than 400 feet of relief in the Port Wasl ington area and possibly elsewhere. The irregularities of the Cretaceous surface are revealed only locally and fortuitously by well-drillirg data.

\section{PLEISTOCENE SERIES}

Deposits of Pleistocene age locally may comprise all or most of the unconsolidated sediments above bedrock and they assume special importance wherever they are part of the ground-water reservoir. Almost 
everywhere, the Pleistocene sand, gravel, and till form the surficial deposits and, because of their variable permeability, determine the rate at which precipitation infiltrates to the main ground-water body. A special effort was made, therefore, to recognize the various glacial and interglacial deposits at the surface and in wells and to establish their age relationships. From his own observations, and in accordance with the opinions expressed by other writers (Fleming, 1935; Flint, 1957; MacClintock and Richards, 1936), the writer favors s simpler sequence of Pleistocene events than that offered by Fuller (1914). Accordingly, the deposits of Pleistocene age are referred to tro glacial stages, separated by an interglacial marine deposit, the Gardiners clay. The pre-Wisconsin deposits, consisting of the Jameco gravel and Gardiners clay, have been recognized only in some wells slong the north shore. The bulk of the Pleistocene deposits, collectively known as the upper Pleistocene deposits, are presumably of Wisconsin age. In the project area they have been grouped into the Ronkonkoma and Harbor Hill drifts. The surficial deposits of the area are shown in plate 8 .

JAMECO GRAVEL AND UN DIFFERENTIATED DEPOSITS OF PLEISTOCENE AGE

The oldest glacial deposit in the project area, probably the Jameco gravel, consists of sand, gravel, and silt lying on bedrock or in valleys cut into the Cretaceous sediments. The deposit apparently i largely glacial outwash from an ice sheet that did not reach Long Island. However, the ice front might have been close to the present north shore (Veatch and others, 1906, p. 34). In the absence of older Pleistocene deposits of known age in the New England-New York area with which it might be correlated (See glacial map of the United States east of the Rocky Mountains, Flint and others, 1ธ59) the Jameco gravel can be dated only as of pre-Sangamon, possibly Illinoian age. Much of the Jameco gravel apparently has been deposited by melt-water streams from different source areas to the north and northwest of Long Island. In contrast to the heterogeneous composition of the formation in the type locality in Queens, the Jamecs gravel in the project area seems to be derived largely from Cretaceous sources and contains only a small admixture of igneous rock pebbles or other erratic material. As in the younger outwash deposits, pelbles of granitic and metamorphic texture may be very slightly or strongly weathered, according to their schistosity or content of minaceous minerals. The Jameco lies from about 150 to 350 feet below sea level in nearshore areas and probably under parts of Long Island Sound and its bays. It is found principally to the north of the limit of the Cretaceous, but also in some valleys cut into the Cretaceous. Commonly it is between 100 and 200 feet thick. (See pls. 4-7.) Pecause 
of lithologic similarity to the Cretaceous and the overlying younger outwash deposits, the Jameco gravel on the north shore of Long Island is not readily identified from well-drillers' samples. Commonly it is recognized only where it is overlain by the Gardiners clay.

Undifferentiated Pleistocene valley fill, consisting largely of sand and gravel, is found also in some of the deeper valleys cut into or through the Magothy(?) formation. (N3521T and N4223T, pl. 7; N5710, pl. 4.) Although this valley fill occurs at somewhat higher altitudes inland, it may be in part equivalent to the Jameco gravel. In most cases it cannot be positively identified.

The Jameco gravel is part of the deep confined aquifer in Sands Point, Port Washington, and Great Neck where locally it is the only source of large supplies of water. Specific capacities of we'ls screened in the Jameco gravel commonly are less than those wells tapping other aquifers (table 11). Estimated permeabilities, computed from specific capacities, range from 140 to $330 \mathrm{gpd}$ per sq ft. Somewhat greater permeabilities were obtained for undifferentiated Pleistocene valley fill, as shown in table 5 .

TABle 5.-Estimated permeabilities of Jameco gravel and undifferentiated Pleistocene valley fill

\begin{tabular}{c|c|c|c|c}
\hline Well & $\begin{array}{c}\text { Screened zone } \\
\text { (feet below laud } \\
\text { surface) }\end{array}$ & $\begin{array}{c}\text { Specific } \\
\text { capacity } \\
\text { (gpm per ft) }\end{array}$ & $\begin{array}{c}\text { Approx. } \\
\text { aquifer } \\
\text { thickness } \\
\text { (feet) }\end{array}$ & $\begin{array}{c}\text { Estimated } \\
\text { permeability } \\
\text { (gpd per sq ft) }\end{array}$ \\
\hline
\end{tabular}

Jameco gravel

\begin{tabular}{|c|c|c|c|c|}
\hline $\begin{array}{r}\mathrm{N}-33 \\
35 \\
38 \\
675\end{array}$ & $\begin{array}{l}239-340 \\
287-387 \\
382-396 \\
269-286\end{array}$ & $\begin{array}{r}9 \\
19 \\
5 \\
7\end{array}$ & $\begin{array}{r}100 \\
150 \\
90 \\
100\end{array}$ & $\begin{array}{l}240 \\
330 \\
140 \\
190\end{array}$ \\
\hline
\end{tabular}

Undifferentiated Pleistocene valley fill

\begin{tabular}{r|r|r|r|r}
\hline N-3540_. & $103-155$ & 13 & 140 & 250 \\
3742 & $230-260$ & 23 & 160 & 340 \\
4223 & $277-330$ & 34 & 200 & 425 \\
\hline
\end{tabular}

\section{GARDINERS CLAY}

A marine formation occurring close to the north shore, in present embayments and former channels, has been recognized in many wells in Great and Manhasset Necks. The formation is corralated with the Gardiners clay. It consists of greenish-brown clay and silt and scattered sand or gravel lenses. Some zones contain plant debris, ranging from fairly fresh to lignitic. The top of the forration usually lies between 50 and 60 feet below sea level; the thickness is variable but commonly ranges from 100 to 200 feet. The formation is 
in part fossiliferous, containing fragments of oyster and clam shells and, commonly, Foraminifera. Of the latter, Elphidium is the most common genus. A fossiliferous zone of some continuity occurs within the Gardiners clay between 80 and 100 feet below sea level in the northern part of Manhasset Neck. (Test borings N4389'T and N6095'T, pl. 6; also N33, N1482, and N4859'T, pl. 5.) No systematic study of the fossil material was possible during the present investigation. Only a detailed ecological study of the microfauna naight give some clues as to the depositional environment of the Gardiners clay of the north shore, including salinity, depth, and temperature ranges. In lithology the Gardiners clay of northwestern Nassau County resembles closely the formation in other parts of Long Island and may in part represent deposition in shallow, brackish water (Weiss, 1954). Nearshore deposition is indicated by vegetable debris and gravelly zones within the clay.

The Gardiners clay was deposited at a time when sea level was perhaps 50 feet lower than at present. Its age and genersl correlation with the Gardiners clay of Cape Cod are dubious. 'T'a formation probably is of interglacial, pre-Wisconsin origin, although an early Wisconsin interstadial age is not impossible (Flint, 1957, p. 359; Hyyppä, 1955, p. 211). Carbon ${ }^{14}$ dates obtained for oyster shells from two localities (Port Washington and Glen Cove) representing the Gardiners clay apparently indicated an age greater than 38,000 years. Radiocarbon age determinations of the samples obtained from outcrops, were made in the laboratory of the U.S. Geological Survey. (Meyer Rubin, written communication, 1957.)

\begin{tabular}{|c|c|c|}
\hline $\begin{array}{l}\text { Lab no. and date of } \\
\text { analysis }\end{array}$ & Description & Age (years) \\
\hline W-611, Oct. 1, 1957 - & $\begin{array}{l}\text { Oyster shells from gray marine clay incor- } \\
\text { porated in till, exposed in stream bed of } \\
\text { Plandome-Port Washington drain, Nas- } \\
\text { sau Knolls Cemetery, Port Washington, } \\
\text { N.Y. }\end{array}$ & $>38,000$ \\
\hline W-613, Oct. 1,1957 & $\begin{array}{l}\text { Shell fragments from marine deposit below } \\
\text { till and outwash on east shore of Hemp- } \\
\text { stead Harbor } 1,000 \mathrm{ft} \text { south of E. M. } \\
\text { Loew estate, Glen Cove, N.Y. }\end{array}$ & $>38,000$ \\
\hline
\end{tabular}

In spite of uncertainties as to its age and origin, the Gardiners clay, because of its fossil content, is a valuable key horizon in the Pleistocene stratigraphy. Previously unpublished logs of wells in which the Gardiners clay has been recognized are included in table 12. Geologic correlations for several wells, given in Suter and others (1949), are revised in the following table to include the Gardiners clay and Jameco gravel units. 


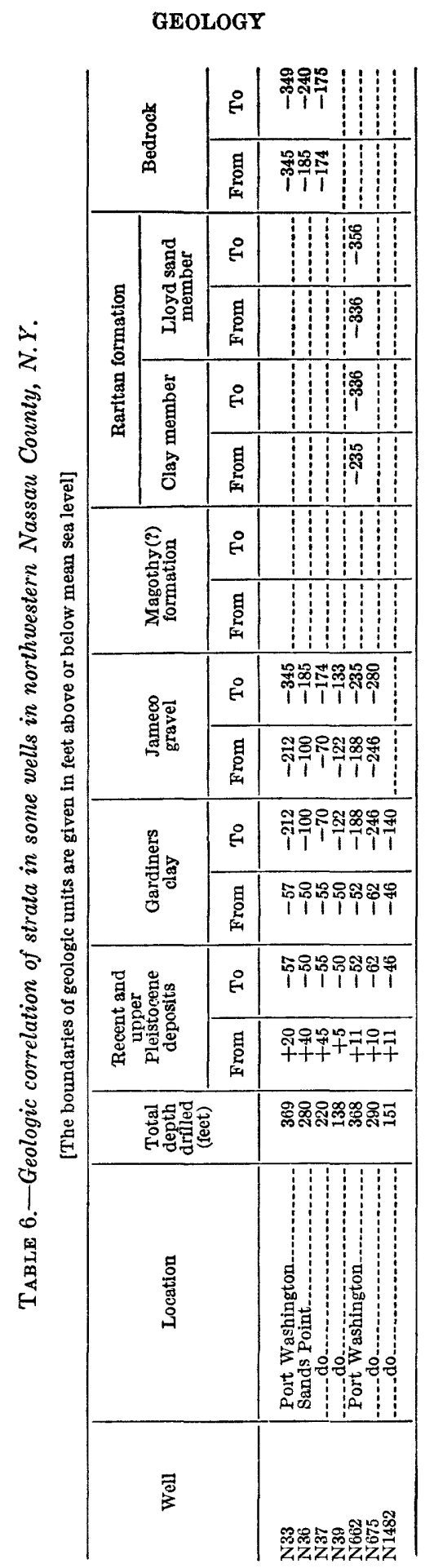


The top of the Gardiners clay commonly is recognized with difficulty, particularly where the formation is overlain directly by fossiliferous marine clays of Recent age. Also, in many places along the north shore the Gardiners has been deformed by the thrusting action of later Pleistocene ice advances and thus may be above sea level. Large masses of the formation were found to be incorporated in the lower of two till sheets in Port Washington, at elevations ranging from a few feet below to 150 feet above sea level.

The Gardiners clay apparently is present in Great Neck, Kings Point, Sands Point, and Port Washington: it may be Fresent also in the north-shore bays and parts of Long Island Sound, where it is dissected by subsequent Pleistocene and Recent erosion. Although the formation is variable enough in thickness and lithology to permit local interchange of water with adjacent formations, it generally constitutes a confining bed creating artesian conditions in the underlying Jameco gravel. Very few wells tap the more permeable zones within the Gardiners and thus yield small supplies of water.

\section{UPPER PLEISTOCENE DEPOSITS}

The term upper Pleistocene deposits was introduced by deLaguna (1948) for all glacial deposits above the Gardiners clay on Long Island. These deposits, presumably of Wisconsin age, consist of stratified drift, till, and some silt and clay of lacustrine origin. Their greatest thickness is in the area of the terminal moraines, where it may reach 200 to 300 feet. In large part, the upper Pleistocene depcsits appear to be related to two ice advances, and they are subdivided in the project area, wherever feasible, into the Ronkonkoma and Harbor Hill drifts. Each of these drifts is composed of a termiral moraine and related till and outwash deposits. The older Ronkonkoma drift is recognized from the Ronkonkoma terminal moraine northward, in most of Manhasset Neck. The Ronkonkoma drift is mantled thinly by outwash gravel between the terminal moraines, but from the Harbor Hill terminal moraine northward the Ronkonkoma drift generally is buried by 80 to 150 feet of Harbor Hill drift. Most of the area's surficial deposits, shown in plate 8 , are associated with the Harbor Hill ice invasion. The relationship of the Harbor Hill and Ronkonkoma drifts to the older deposits is indicated on geologic section $C-C^{\prime}$, plate 6 .

Although the bulk of the upper Pleistocene deposits lier above the zone of saturation in much of the project area, the permeable sand and gravel deposits of the Ronkonkoma and Harbor Hill drifts yield water to many wells in areas where the Magothy(?) formation occurs at low altitudes or has been eroded. The upper Pleistocene deposits constitute an important source of water in Great Neck, Sends Point, 
northeastern Queens, and particularly the area of the outwash plain south of the Ronkonkoma and Harbor Hill terminal moraines. Wells screened in the glacial outwash deposits, generally at deptl $\backsim$ of less than about 130 feet, yield as much as $1,400 \mathrm{gpm}$. The specific capacities of these wells, commonly between 40 and $60 \mathrm{gpm}$ per foot of drawdown, generally are greater than those of wells tapping Cretaceous formations (table 11). Permeability coefficients of the outwash materials commonly range from about 800 to $1,000 \mathrm{gpd}$ per sq. ft. and, exceptionally, may be as great as 2,000 gpd per sq. ft. (N15, table 11). Relatively impermeable till, associated with both moraines at the surface and at depth occurs north of the outwash plain; it may cause perched-water conditions or retard infiltration of precipitation. (See p. 29.)

\section{RONKONKOMA DRIFY}

The Ronkonkoma drift, consisting of a terminal moraine of the same name and related outwash deposits and till, rests upon the Magothy(?) and early Pleistocene deposits. The Ronkonkoma terminal moraine is relatively indistinct in western Nassau County, where it is largely mantled by younger outwash and rises but slightly above the surrounding pitted outwash plain. However, it can be traced westward from Albertson to Lake Success, where it merges with the Harbor Hill terminal moraine. (See pl. 8.) A sheet of till, recognizable in many wells, and apparently fairly continuous, has been traced beneath younger drift southward from IManhasset Neck to the position of the Ronkonkoma terminal moraine (wells N3732, N5947, and others, shown on section $\left.C-C^{\prime}, \mathrm{pl} .6\right)$. This ti.l sheet is generally 10 to 20 feet thick and consists of compact clayey or sandy boulder till. The top of the till generally is at altitudes slightly above 100 feet but may be as high as 150 to 170 feet above sea level. In many places the till is highest wher 3 the Cretaceous surface is high; and these highs coincide also with some of the highest altitudes along the younger Harbor Hill terminal moraine. The till, extending southward from Manhasset Neck and Harbor Hill to North Hills and Albertson, is correlated here with the older till exposed in several gravel pits on the west shore of Tempstead Harbor at altitudes of about 100 feet above sea level. $T^{\prime}$ e till and the underlying outwash gravel, respectively the Montauk till member and the Herod gravel member of the Manhasset formatior described by Fuller (1914, p. 114) are interpreted here as the ground moraine and advance outwash deposits of the Ronkonkoma ice invasion. 
The Harbor Hill drift consists of a terminal moraine, a veneer of ground moraine, and various outwash deposits related to th 9 advance, stagnation, and waning of the latest, or Harbor Hill, ice; their distribution is shown in plate 8. Stratified sand and gravel deposits above the Ronkonkoma drift or, as in Great Neck, directly upc 7 the Cretaceous, apparently represent advance outwash from the Harbor Hill ice. These deposits, generally 20 to 50 feet and in places as much as 80 feet thick, probably include the Hempstead grarel member of the Manhasset formation described by Fuller. They were well exposed in several gravel pits on Manbasset Neck in 1957. (See pl. 8.) North of the Harbor Hill Terminal moraine, these outwash deposits are covered by a veneer of ground moraine, usually a clayey or sandy till containing boulders; it is generally 5 to 10 feet but locally as much as 40 feet thick and in places very compact. The Harbor Hill terminal moraine, a distinct northeast-trending ridge, consists largely of ice-contact deposits which, in their alignment, indicate the position of an ice front that was stable for a considerable time. Isolated or coalescing kames and interspersed kettle holes account for the irregular surface of the moraine. Steeply inclined, crudely stratified sand and gravel deposits showing slump and collapse fe tures arecharacteristic in the area. Till is generally present within the Harbor Hill terminal moraine but highly irregular in distribution and thickness. The morainal ridge is breached in several places by melt-waterchannels which continue the southerly trend of the north-shore bays. The channel fill consists of stratified sand and gravel, pres"mably of late-glacial or early post-glacial age. Other stratified deposits associated with the waning stages of the Harbor Hill ice include kame deltas and kame terraces on Manhasset and Great Necks, as shown in plate 8. A glacial outwash plain of stratified sand and gravel slopes southward from the terminal moraine. The surface of this plain is'somewhat irregular and pitted by kettle holes as far south as the Ronkonkoma terminal moraine, but the surface becomes relatively smooth farther south.

\section{AGF OF THE UPPER PLEISTOCENE DEPOSTTS}

No evidence is available that would justify the subdivision of Long Island's upper Pleistocene deposits into units representing more than one glacial stage. All deposits above the Gardiners clay seem to be closely related to the two ice advances that produced the Ronkonkoma and Harbor Hill terminal moraines. There are no significant erosional: intervals or fossil-soil development anywhere in the upper Pleistocenesequence; there are no obvious lithologic differences between the oldest and youngest outwash deposit and there is no differerce in the. 
degree of weathering of rock pebbles in till or outwash that can be attributed readily to variations in mineral composition and texture. Thus, apparently no great time elapsed between the Ronkonkoma and Harbor Hill ice advances, which, therefore, might be considered episodic within one glacial stage. MacClintock and Richards (1936, p. 336) and Flint (1957, p. 356) also consider the Pleistocene deposits of Long Island above the Gardiners clay to be of Wisconsin age.

\section{RECENT SERHES}

Deposits of Recent age are found along the shorelines, in stream valleys, in swamps and marshes, and offshore (pl. 8). The deposits. include sand and gravel on beaches and bars, a minor amcunt of silty alluvium deposited by streams, and organic silt in fresh-water swamps. and peat bogs. Some of the peat bogs occupy depressions underlain by till and apparently represent sites of more or less continuous accumulation of lake sediments and peat since early post-glacial time. A large deposit of peat in the southeastern part of Manhasset Neck is as much as 18 feet thick. Swamp and peat deposits also are extensive in Kings Point and along the Ronkonkoma terminal moraine, north of Garden City Park. A radiocarbon age of approximately 5,300 years was determined in the laboratory of the U.S. Geological Survey (Rubin, Meyer, written communication, 1959) for a Foat sample obtained directly above the youngest till on Manhasset Neck.

\begin{tabular}{c|c|c}
\hline $\begin{array}{c}\text { Lab no. and date of } \\
\text { analysis }\end{array}$ & Description & Age (years B.P.) \\
\hline $\begin{array}{l}\text { W-716, June 3, } \\
1959 .\end{array}$ & $\begin{array}{l}\text { Plant debris, partly lignitized, in contact } \\
\text { with till, depth ft. From humus and } \\
\text { peat deposit which overlies youngest till } \\
\text { (ground-moraine) in area. Property of } \\
\text { Landuhl Co., West Shore road, south } \\
\text { of Colonial Sand and Stone Co. gravel pit, } \\
\text { Flower Hill Estates, Port Washington, } \\
\text { N.Y. 5. }\end{array}$ \\
\hline
\end{tabular}

Of particular hydrologic importance are the silt and clay now accumulating in the north-shore bays and Long Island Sound. $\mathrm{Al}$ though these deposits, several tens of feet thick, may contain intercalated gravel lenses, they generally are impermeable enough to retard leakage of fresh water from the underlying strata into the bays. Because of their relatively small extent and common association with salt water, the deposits of Recent age do not constitute a major source of water. 


\section{SUMMARY OF THE GEOLOGIC HISTORY}

Detailed descriptions of Long Island's geologic history wer? written by Fuller (1914, p. 192) and deLaguna (in Suter, 1949, p. 29). Although the knowledge of geologic events in the Long Island area is incomplete, a review of known events helps in understanding the areal extent and nature of the geologic formations. Reference to the distribution and lithologic character of the formations, as these factors affect the occurrence of ground water in the project area, has been made in the preceding pages. Therefore, only a summary of geologic events applicable to western Long Island and the project area is given below.

Subaerial erosion, beginning in the late Triassic and extending into Jurassic time, reduced the Long Island area to a plain of $\mathrm{l} \times \mathrm{v}$ relief, the so-called Fall Zone peneplain. This plain, which was cut into crystalline and sedimentary rocks, was slightly above sea level. Uplift of a large sector of the earth's crust in eastern North America, in early to mid-Cretaceous time, centered along the axis of the Appalachian Mountains. This uplift was accompanied by gentle tilting of the Fall Zone peneplain to the southeast, depressing the Long Island area while elevating the land to the west and north. Erosion of the newly created highlands provided the sediments which were deposited in the Long Island area as the Raritan and Magothy(?) formations of Late Cretaceous age. Most of these sediments indicate a coastalplain environment of deposition, either in stream channels and on flood plains along the lower reaches of streams, or in shallow water offshore. The period of deposition, representing tens of millions of ye ${ }^{\wedge} \mathrm{rs}$, was sufficiently long to include major oscillations of the shoreline. Thus, cycles of deposition were interrupted by periods of relative'y more intense erosion. Renewed tilting of the bedrock to the southeast is inferred from the thickening of the formations southeastward.

Presumably the sea receded from the area that is now Long Island near the close of the Cretaceous, and erosion was dominant during much of Tertiary time. The uplifted Cretaceous sediments were dissected by consequent southward-flowing streams and their tributaries. The tributaries eventually became major subsequent streams, following outcrop areas of relatively less competent strata. The present depression of Long Island Sound apparently had its origin in a subsequent valley eroded along the contact of the Lloyd sand member of the Raritan formation with the crystalline bedrock to the north. The southern boundary of the depression was a cuesta-like ridge of hills interrupted by transverse valleys. The cores of these hills were composed of the more erosion-resistant clay member of the Raritan formation. 
No definite evidence of early Tertiary strata has been found on Long Island. However, by analogy with strata in the central and southern parts of the Atlantic Coastal Plain, post-Cretaceous merine strata may be expected to exist seaward of the Raritan and I Aagothy(?) formations, near the present south shore of Long Island (Perlmutter and Crandell, 1959, p. 1066). Tertiary deposits also may exist on the island in some of the major buried valleys which are not well defined at the present time. A gravel deposit capping the Mannetto Hills, the Mannetto gravel of Fuller (1914) has local distribution in eastern Nassau and western Suffolk Counties but has not been recognized in western Long Island. Fuller (1914, p. 85) suggests that this deposit may be of early Pleistocene age, but Crosby (unpublished report, 1910, p. 52) states that it may be of Pliocene age.

A pre-Wisconsin stage of Pleistocene glaciation is reprosented by the Jameco gravel, an outwash deposit from an ice sheet which presumably did not reach Long Island. The stratigraphic position of the Jameco gravel indicates that sea level was perhaps 350 to 400 feet lower than at present. As a result, accelerated erosion may have re-excavated or deepened some of the pre-existing Tertiary valleys and also cut some new valleys. This erosion probably also removed much of the remaining Cretaceous and Tertiary deposits from some areas of Long Island Sound and its tributary valleys, while the Janeco gravel was being deposited in other areas. Much of the Jameco gravel in the project area is apparently eroded from Cretaccous sources and was redeposited by melt water streams.

The next event in Long Island's geologic history is racorded by the Gardiners clay, a marine formation, which overlies the Jameco gravel in the project area and also in the southwestern part of the island. The interglacial (Sangamon?) Gardiners clay probably was deposited when sea level was about 50 feet below its present position.

The beginning of the Wisconsin glacial stage presumably was accompanied by a renewed lowering of sea level and erosion of the Gardiners clay. However, the relatively shallow depth of erosional channels in the Gardiners in western Long Island seems to indicate a position of sea level perhaps 100 to 150 feet lower than at present. Eustatic lowering of sea level, brought about by retention of moisture from the oceans in continental ice masses, probably was as much as 290 to 380 feet (Flint, 1957, p. 260). Isostatic adjustments to the weight of the superimposed ice or to its removal have not been recognized in Long Island. Such crustal movements were probably small or regligible in the area marginal to the continental ice sheets and would tend to decrease the total amount of relative emergence or submergence. The position of an ice front that was stable for considerable time in the Long Island area is marked by the Ronkonkoma terminal moraine.

$690-186-63-3$ 
Associated with the ice invasion are advance outwash, ice-contact deposits, and till, described collectively as Ronkonkoma drift (p. 45). Ice shove produced strong deformation of the Gardiners clay and older formations along the entire north shore of Long Island and locally incorporated large masses of these materials in the drift. The Ronkonkoma ice front subsequently retreated an unknown distance to the north of Long Island, then apparently readvanced to another position of relative stability marked by the Harbor Hill terminal moraine. Various outwash deposits and till (Harbor Hill drift, p. 46) are related to the advance, stagnation, and waning of the litest, or Harbor Hill, ice in the area. Glacial lakes were formed in some depressions along the north shore of Long Island during the wasting stages of both ice invasions. In post-glacial time erosion and deposition proceeded under conditions of fluctuating sea level. Recent sediments accumulated in some of the Pleistocene valleys and northshore bays, and sea level rose to its present position in the mo $t$ recent past.

\section{HYDROLOGY}

\section{GROUND WATER}

GeNGRAX Features

The ultimate source of the ground water is precipitation. Of the total precipitation, part returns directly to the atmosphere, part infiltrates the ground, and part runs off overland in streams draining into Long Island Sound or the ocean. Much of the water moving downward into the soil and subsoil is retained at shallow depth as soil moisture, which is subject to evaporation and the demands of plant growth. During the summer, evapotranspiration may return moisture to the atmosphere at rates similar to or exceeding those of precipitation. During the remainder of the year, water available after the soil-moisture requirements have been met moves down through the Pleistocene and Cretaceous strata to the water table and becomes ground water. Some of the water eventually reaches the deeper strata by downward percolation-chiefly from the main area of recharge on the ground-water divide in the southeastern part of the project area and locally from areas of recharge on Manhaset and Great Necks. Ground water discharges by upward leakage from the deeper strata along the coast, offshore, in springs along the shores, and by ground-water outflow in the lower reaches of stream valleys.

Unconsolidated deposits of Cretaceous and Pleistocene g ge form the bulk of the ground-water reservoir. The intergranular space of all these deposits is saturated from the weathered bedrock upward to the water table, which represents the upper limit of the zone of saturation. Where the upper part of the zone of saturation is in 
permeable beds, ground water is unconfined or under water-table conditions. Ground water confined under pressure beneath relatively impermeable strata is called confined or artesian. The water may be under sufficient pressure to flow at the land surface, where tapped by a well. Flowing wells are common near the shores of some bays and harbors leading into Long Island Sound.

Ground water in the project area is under virtually all degrees of confinement, ranging from water-table to artesian. Also, locally, bodies of ground water are perched above the main water table and separated from it by an intervening unsaturated zone. Ground water is perched where the downward migration of water is impeded by a relatively impermeable stratum, which results in a local zone of saturation unrelated to the main water table.

All the water in the ground-water reservoir can be considered to constitute a single hydraulic system, but the more permeable zones within the reservoir are called aquifers. An aquifer is a discrete hydrological unit that is capable of yielding water to wells or springs in substantial quantities; it may be comprised of one formation, part of a formation, or group of formations. Impermeable strata in the reservoir that confine or retard the flow of ground water are known as aquicludes or aquitards, respectively.

\section{WATER-BEARING UNITS}

In the project area, the ground-water reservoir includes three discrete aquifers which consist of parts of either one or two contiguous geologic formations. For identification and discussion, these are designated as the shallow unconfined, the principal, anc the deep confined aquifers. In addition to these aquifers, local bodies of perched ground water also are discussed in following sections.

\section{BODIES OF PERCHED WATER}

Although bodies of perched water are found at seviral places in the northern part of the project area, they are not used as a source of water. Areas in which isolated bodies of perched water commonly occur are outlined in figure 5. Perched water occurs clise to the land surface in depressions that are underlain by clayey till, particularly in the area of ground moraine north of the Harbor Hill terminal moraine. Perched-water zones also associated with till are common within the Harbor Hill and Ronkonkoma terminal moraines, which are shown in plate 8. A sheet of relatively impermeable older ground moraine from the Ronkonkoma terminal moraine northward to Manhasset Neck causes ground water to be perched, commonly several tens of feet below land surface, in that area. Isolated bodies of perched water are found in clay-bottomed kettle holes within the moraines, in the intermorainal area, and on the outwash pla in slightly south of the moraines. 


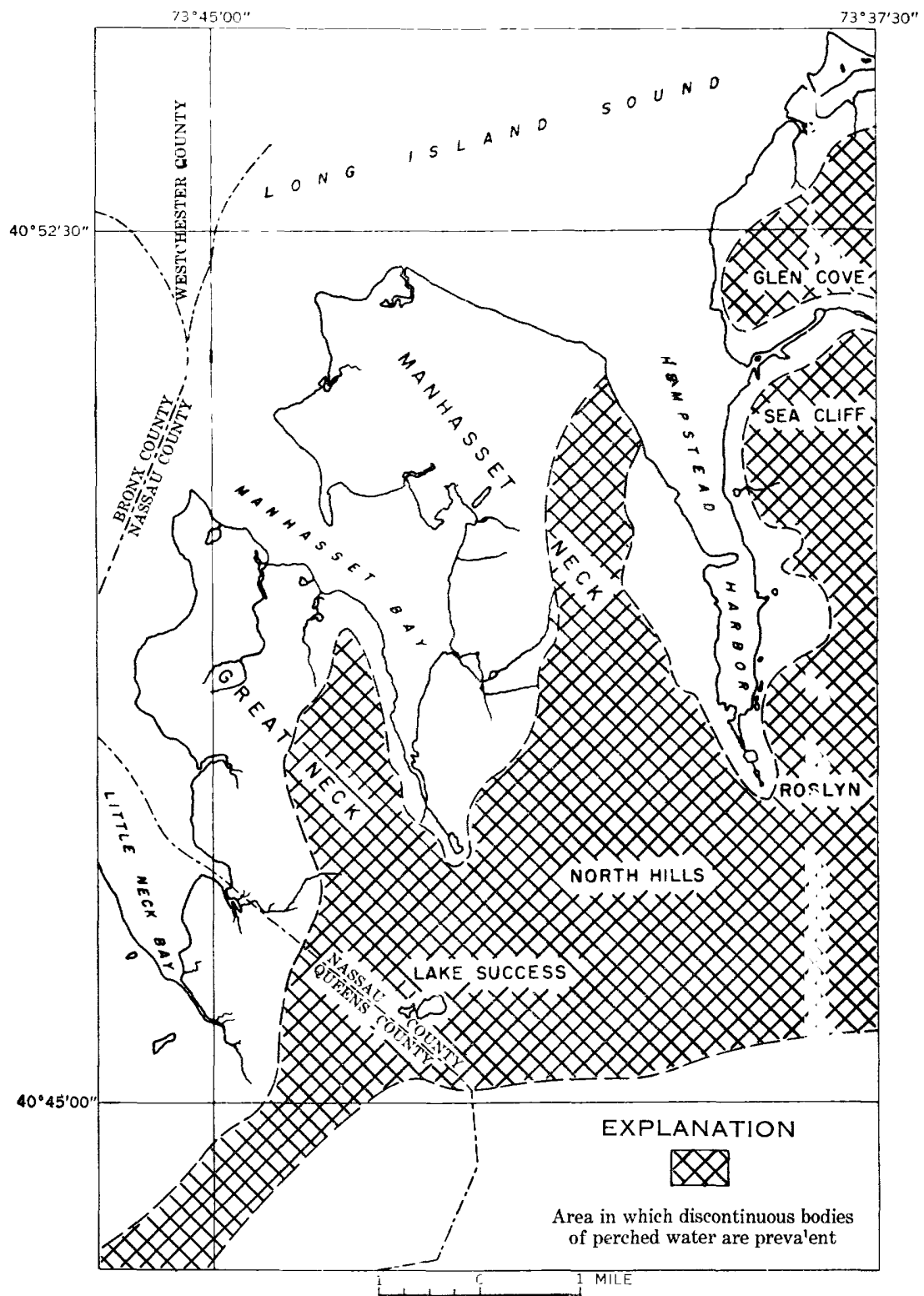

FIGURE 5.-Map of northwestern Nassau and northeastern Queens Counties, N.Y., showing areas of perched water.

\section{SHALLOW UNCONFINED AQUIFER}

The shallow unconfined aquifer consists of those permeable Pleistocene and Cretaceous deposits that lie below the main water table and within the upper part of the zone of saturation, from slightly 
below to a little more than 110 feet above sea level. Contours on the main water table are shown in plate 9. The shallow unconfined aquifer is a source of water where it occurs in sand and grarel deposits, particularly in the glacial outwash plain south of the Farbor Hill terminal moraine. Owing to the irregular distribution of Cretaceous clay and other beds of low permeability within the aquifer in the vicinity of Kings Point and Port Washington, the we.ter-bearing materials in these area are more discontinuous than elsewhere. Nevertheless, small supplies of water are obtained from the aquifer for domestic and industrial purposes in many parts of the Manhasset and Great Neck peninsulas. Also, of considerable importance rs sources of water are the permeable deposits in the shallow aquifer in northeastern Queens County and in Sands Point, beyond the northern limit of the principal aquifer-that is, in areas where these deposits lie directly above the clay member of the Raritan formation or the Gardiners clay. In 1957, about $5 \mathrm{mgd}$ (million gallons per day) of grounc water was withdrawn from the shallow unconfined aquifer in the project area.

\section{PRINCIPAL AQUTFER}

The principal aquifer corresponds approximately to that part of the Magothy(?) formation which occurs from about 50 feet below sea level downward to the top of the clay member of the Raritan formation. In places, moreover, the aquifer includes Pleistocene deposits which blanket the Magothy(?) or lie in channels cut into it. Some pre-Wisconsin channels, which cut to or slightly in to the c'ay member of the Raritan formation and are filled with undifferentiated Pleistocene deposits, have been noted (pls. 4-7), and other channels undoubtedly exit in the area. The channel fill is generally of coarser texture than the adjacent Magothy(?) deposits with which, however, it is hydraulically continuous. The areal extent of the principal aquifer is indicated in plate 10 . The principal aquifer terminates in the center of Great and Manhasset Necks, somewhat south of the northern limit of the Cretaceous deposits shown in plate 3. The presence of the clay member of the Raritan formation near sea level and the truncation of the Magothy(?) by erosion limit the extent of the principal aquifer northward (pl. 10). Beyond this limit, the principal aquifer merges with the shallow unconfined squifer.

Hydrostatic heads in the principal aquifer are commonly from a foot to several feet below those in the shallow unconfined aquifer, except in the Port Washington area, where they are as much as 85 feet lower. Hence, the principal aquifer can receive water by downward movement through permeable and relatively impermeable zones, which include discontinuous clay lenses of both the Magothy(?) and the Pleistocene. Although hydraulic continuity kotween the 
shallow unconfined aquifer and the upper part of the principel aquiter, is fairly good locally, artesian conditions generally prevail in the deeper part of the principal aquifer. The principal aquifer is the chief source of water in most of the project area, except the peninsulas. In 1957 about $28 \mathrm{mgd}$ was withdrawn from wells screened in the basal zone of the Magothy(?) formation and other permeable zones in the Magothy(?) and deeper Pleistocene deposits.

\section{DEEP CONFINED AQUIFER}

The deep confined aquifer consists of the Lloyd sand member of the Raritan formation and the Jameco gravel and underlies the entire project area. The lower limit of the aquifer is the bedrock surface; the upper limit is the clay member of the Raritan formation and the Gardiners clay. The Gardiners clay may abut the clay member on the north, where the deposits of Cretaceous age have been eroded, or it may lie directly upon the clay member, as it does in some valleys and embayments. Thus, the Lloyd sand member of the Raritan formation (Cretaceous) and the Jameco gravel (Pleistocene) are connected hydraulically in the northern part of Manhasset and Great Necks. The two contiguous clay bodies overlying the aquifer, the clay member of the Raritan formation and the Gardiners c'ay, form effective confining beds, which probably extend beyond the shoreline of the project area. These stratigraphic relations are showr in three geologic sections (pls. 4-6). The vertical limits of the deep confined aquifer are shown on the hydraulic profile (pl. 12).

As hydrostatic heads in the deep confined aquifer (pl. 11) are commonly from 5 to 50 feet lower than those in overlying aquifers, downward leakage of water from the shallow unconfined and principal aquifers through the clay member of the Raritan formation and the contiguous Gardiners clay is possible in most of the area.

Hydraulically, the deep confined aquifer is the most perfectly confined of the water-bearing units. The degree of confinement is demonstrated by the fact that interference effects in the acuifer are recognized from centers of pumping as much as 10 miles away from the project area. In contrast, the effects of pumping on the principal and shallow unconfined aquifer generally are observed onl $\%$ within a radius of less than half a mile from pumped wells. The deep confined aquifer is a major source of water in the northern part of the project area, particularly on Manhasset and Great Necks. Locally, it is the only source available for large public supplies or industrial needs. About $7 \mathrm{mgd}$ was withdrawn from the aquifer in 1957.

THE WATER TABLE AND PHEZOMETRIC GURFACES

Hydrostatic pressures in each of the aquifers in the project area can be related to a water table or associated piezometric surfaces. 
The shape and slope of these surfaces are determined chiefly by the thickness, areal extent, and permeability of the aquifer materials and the quantity of water moving through them. Moreover, each surface expresses a dynamic equillibrium among all factors affecting recharge and discharge relationships, both natural and artificial, within the aquifer. Variations in any one of the factors may produce changes in the position of the surface and concomitant changes in storage and pressure in the aquifer and adjacent aquifers.

The configuration of the water table, which marks tha top of the shallow unconfined aquifer, is shown in plate 9 by contours referred to sea level and is based on water-level measurements made in wells during April 1957. From figure 14 it is apparent that a bigh position, which is also on the main water-table divide of Long Irland, lies in the Albertson-East Williston area about 2 $\frac{1}{2}$ miles south of the Harbor Hill terminal moraine. (Position of moraine shown on pl. 8.) Along this divide, which occurs in relatively permeable outwesh deposits, the water table reaches altitudes of 75 to 80 feet above sea level. The water table slopes from the divide area to the northwest, west, and southwest, at gradients of about 5 to 6 feet per mile near the divide, steepening to about 10 feet per mile toward the southwest. In the southern parts of Manhasset and Great Necks; there is a pronounced flattening in the northwesterly slope from the main divide, and near the margins of Little Neck and Marhasset Bays and Hempstead Harbor (pl. 9) the water table assumes steep bayward gradients of 25 to 35 feet per mile. The shape of the water table in the central and northern parts of Manhasset and Great Necks is controlled essentially by local recharge and geologic conditions. More or less isolated ground-water mounds are indicated by closed water-table contours above an altitude of 25 feet on Great Neck and 60 feet on Manhasset Neck. Although the presence of these mounds is favored by the topography of the peninsulas, the high position of the water table is largely the result of zoner of low permeability within the zone of saturation. Thus, water-table altitudes of more than 110 feet on Manhasset Neck are due to the presence within the upper part of the ground-water reservoir of rather impermeable till zones and Cretaceous deposits, the latter occurring as buried erosional remnants and ice-shoved masses. Sharply defined troughs in the water table around Little Neck and Manhasset Bays and Hempstead Harbor, and the fact that water-table contours are restricted to land areas, indicate that the shallow unconfined aquifer terminates at the shore lines of these salt-water bodies where groundwater is discharged.

The piezometric surface of the principal aquifer based on measurements in observation wells in April 1957 is shown in plate 10. The 
shape and slope of the piezometric surface is generally a somewhat subdued replica of the water table (pl. 9). The pronounced mound in the water table on Manhasset Neck is apparently reflected by a ground-water nose in the piezometric surface somewhat west of the high point on the mound. Also, pumping centered around well N2030 has created a marked cone of depression, indicated by the 25-foot depression contour in the piezometric surface, and hes locally distorted the shape of the ground-water nose. Troughs in the piezometric surface are focused on Manhasset Bay and Hempstead Harbor and indicate direct ground-water discharge from the principal aquifer to these salt-water bodies. However, in contrast to the shallow unconfined aquifer, the piezometric surface shows that the principal aquifer probably extends beneath the southern parts of thase bays but terminates somewhat farther north near the limit of the aquifer, as indicated in plate 10 .

The piezometric surface of the deep confined aquifer in April 1957, as shown in plate 11 , is based on measurements made 8 to 12 hours after cessation of pumping in most wells tapping this aquifer in the project area. Owing to rapidly changing heads within this aquifer that are caused by pumping, it is difficult to depict a representative piezometric surface. However, the piezometric surface pres?nted in figure 16 may be generally representative for average daily recovery of water levels during most of the year, when withdrawals from the aquifer in the project area average about 6 to $7 \mathrm{mgd}$. Withdrawals during the summer are considerably larger, as much as $14 \mathrm{mgd}$ in July 1955, and the piezometric surface in July 1955 undoubtedly was markedly different from that shown in figure 16. Depression contours on plate 11 indicate, somewhat schematically, the larger public-supply and industrial pumping centers that were in operation during the spring of 1957. The cones of depression are indicative of partial recovery of water levels after pumping; their gradients and lateral extent vary from day to day, according to the rates of antecedent pumring and the particular combinations of pumping wells. Although the natural shape of the piezometric surface is distorted by pumping efferts, it is apparent from plate 11 that the general slope of the surface is westerly-declining from an altitude of somewhat more than 20 fect, on the east side of the project area to less than 4 feet on the sonthwest. Thus, across the project area, the average gradient is about 2 to 3 feet per mile. The closed 14-foot contour in the south-central part of Great Neck may reflect local recharge by downward leakage from the principal aquifer or possibly may be a residual high, comparatively unaffected by nearby pumping. Also the pronounced noses on the piezometric surface in the northern parts of Manhasset and Great Necks presumably indicate local areas of downward leakage from the 
shallow unconfined aquifer. On the west side of Manhasset Neck is a cone of depression, marked by a re-entrant in the 2-fost contour, in which the piezometric surface has been depressed by pumping to positions considerably below sea level. This situation, of course, is conducive to salt-water encroachment from Manhasset Bay into the deep aquifer. As indicated by the piezometric contours, the deep confined aquifer extends beneath all the land area of the project and probably also beneath Little Neck Bay, Manhasset Bay, and Hempstead Harbor.

\section{RECHARGE}

The ground-water reservoir in the project area is repler ished under natural conditions solely by precipitation, which in Nas`au County averages about 43 inches annually. Of this, perhaps 50 percent reaches the water table at an average recharge rate in Nassau County equivalent to about $1 \mathrm{mgd}$ per square mile. This rate of recharge is probably high for the northern part of the project area, where the relatively steep topography, near-surface till, and Cretaceous clay impede infiltration and increase overland runoff. Thus, recharge to the water table within the project area ( 63 square miles) may be little more than $55 \mathrm{mgd}$. Even under optimum conditions, recharge to the water table is chiefly dependent upon precipitation during the season when plant growth is dormant. The infiltration from summer rains is to a large extent intercepted by growing plants, and groundwater replenishment may be negligible during the groving season. Nornally, precipitation in Nassau County is fairly evenly distributed throughout the year.

The principal and deep confined aquifers are replenishec entirely by downward percolation of water from the shallow unconfned aquifer through the more permeable zones within confining clay bodies and even, directly but slowly, through the clay. Whereas recharge areas for the principal aquifer coincide generally with areas of high water table in the shallow aquifer and flow directions in both aquifers are similar, water in the deep confined aquifer, particularly in the Lloyd sand member of the Raritan formation, apparently originates chiefly in eastern Nassau County-mostly east of the project area. However, the deep confined aquifer also receives local increments of recharge within the project area, as indicated by the contours on its piezometric surface (pl. 11) in Manhasset and Great Necks.

Recharge to the deep confined aquifer through the confining clay may be estimated by application of a modified equation expressing Darcy's law:

$$
Q=P I A
$$

in which $Q$ is the discharge in gallons per day; $P$ is the coefficient of permeability, in gallons per day per square foot; $I$ is the hydraulic 
gradient in feet per foot; and $A$ is the cross-sectional area in square feet through which the discharge occurs. Assuming permeabilities of 0.001 to 0.1 for the clay and a head loss of 50 feet through 200 feet of clay, the following recharge rates can be computed:

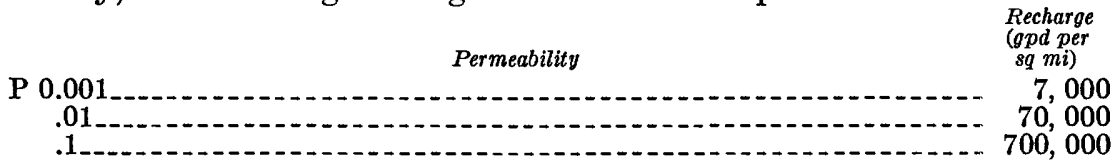

These values, of course, give only possible orders of magnitude for rates of recharge to the deep confined aquifer. They also indicate that the rates may range between wide limits, depending on permeability.

Natural infiltration of precipitation in parts of Nassau County has been disrupted by the growth of densely populated and industrialized areas. The problem of disposing of storm waters from impervious paved areas has been solved by the construction of short stor'n-sewer lines terminating in recharge basins. Of Nassau County's 425 recharge basins constructed since 1935 , about 65 are within the project area. Most of these are south of Northern Boulevard ( $F$ ?.1) in populated areas which lack natural drainage channels. Their designed storage capacity is determined by the area to be drained; the basins are commonly 12 to 15 feet deep and range in size from less than 1 to several acres. Storm water seeps from these basins through the underlying sand and gravel deposits to the water table, thereby providing artificial replenishment of the ground-water reservoir. Inasmuch as drainage in much of the project area is poor, some of the basin merely serve as collecting points for storm water, which may ultimate'ly reach a more favorably situated basin by means of overflow drains. Seepage rates from each basin vary according to natural permeabilities of the underlying material, maintenance of the basin, antecedent precipitation, temperature, and head of the collected waters. In ar experimental recharge basin near Mineola, infiltration rates ranging from 20 to $400 \mathrm{gpd}$ per square foot under various conditions were determined by the Surface Water Branch of the U.S. Geological Survey (Brice and others, 1959).

Artificial recharge to the water table also is effected by neans of cesspools and septic tanks. Thus, perhaps $15 \mathrm{mgd}$ or about half the water pumped for public supply in the project area in 1957 was returned to the ground, while about $15 \mathrm{mgd}$ was discharged as treated sewage directly to Long Island Sound and the ocean. However, the expansion of sanitary sewers discharging to tidewater may eventually eliminate this source of ground-water replenishment. As required by law, most of the ground water pumped in Nassau County for ir dustrial and cooling purposes is returned to the ground by sumps and diffusion 
wells. Thus, $18.0 \mathrm{mgd}$ or 75 percent of the total industrial pumpage in Nassau County (24.3 mgd) was returned to the ground-water reservoir in 1957 . Of $18.0 \mathrm{mgd}$, it is estimated that about $6 \mathrm{mgd}$ was returned to the ground in the project area.

\section{MOVEMENT}

Ground water moves along flow lines from points of high head to points of low head. The rate of movement depends upon the permeability of the materials in the reservoir and relative differences in head. The bulk of ground-water flow in an aquifer is in t] $a$ direction of the steepest gradient and normal to contour lines, as shown on the water-table (pl. 9) and piezometric maps (pls. 10, 11); yet tl nre may be minor flow components oblique to the principal flow direction. In the shallow unconfined aquifer, most of the water moves from the main water-table divide in the Albertson-East Williston area toward the northwest, west, and southwest (pl. 9). However, in the southern parts of the Manhasset and Great Neck peninsulas, much of the northward and northwestward flow from the main divide is intercepted and diverted laterally by east-west valleys, such as those of the Cutter Mill and Flower Hill drains, that cross the peninsulas. Es,ch of these peninsulas contains a well-developed ground-water mound in the shallow aquifer, and from these mounds the shallow ground water flows radially outward to bounding salt-water bodies. However, from the apices of both mounds, most of the flow apparently i westward because of masses of rather impermeable Cretaceous deposits at altitudes of 50 to more than 100 feet along the eastern margins of both peninsulas.

Ground-water flow in the principal aquifer (pl. 10) is generally westward and northward-similar to that in the shallow unconfined aquifer but not coinciding everywhere. In the area of the main ground-water divide, pressure heads in the principal aquifer are a foot to a few feet lower than the water table, and water moves downward from the shallow aquifer into the principal aquifer. A head difference of approximately 5 feet between the water table (well N1140) and the basal zone of the principal aquifer (well N575) has been observed in Garden City (pl. 12). The vertical interval between the screens of wells N575 and N1140 is about 460 feet, which is the maximum known interval in the project area between the two aquifers. In parts of Port Washington on Manhasset Neck, heads in tl a principal aquifer are as much as 85 feet lower than those in the shallow aquifer (pls. 9, 10). As little downward movement of water from the shallow unconfined aquifer seems possible in this area because of highly impervious clay bodies, the principal aquifer apparently receives water almost entirely by flow from the south. 
Pressure heads in the principal aquifer in an area peripheral to the southern parts of Manhasset Bay and Hempstead Harbor are commonly higher than the water table and also higher than the heads in the deep confined aquifer. Thus, water in this area can move upward into the shallow aquifer or into salt-water bodies as well as downward into the deep confined aquifer. The pressure relationships of shallow, principal, and deep aquifers at the southern ends of Little Neck Bay, Manhasset Bay, and Hempstead Harbor are shown in figure 6. Pres-
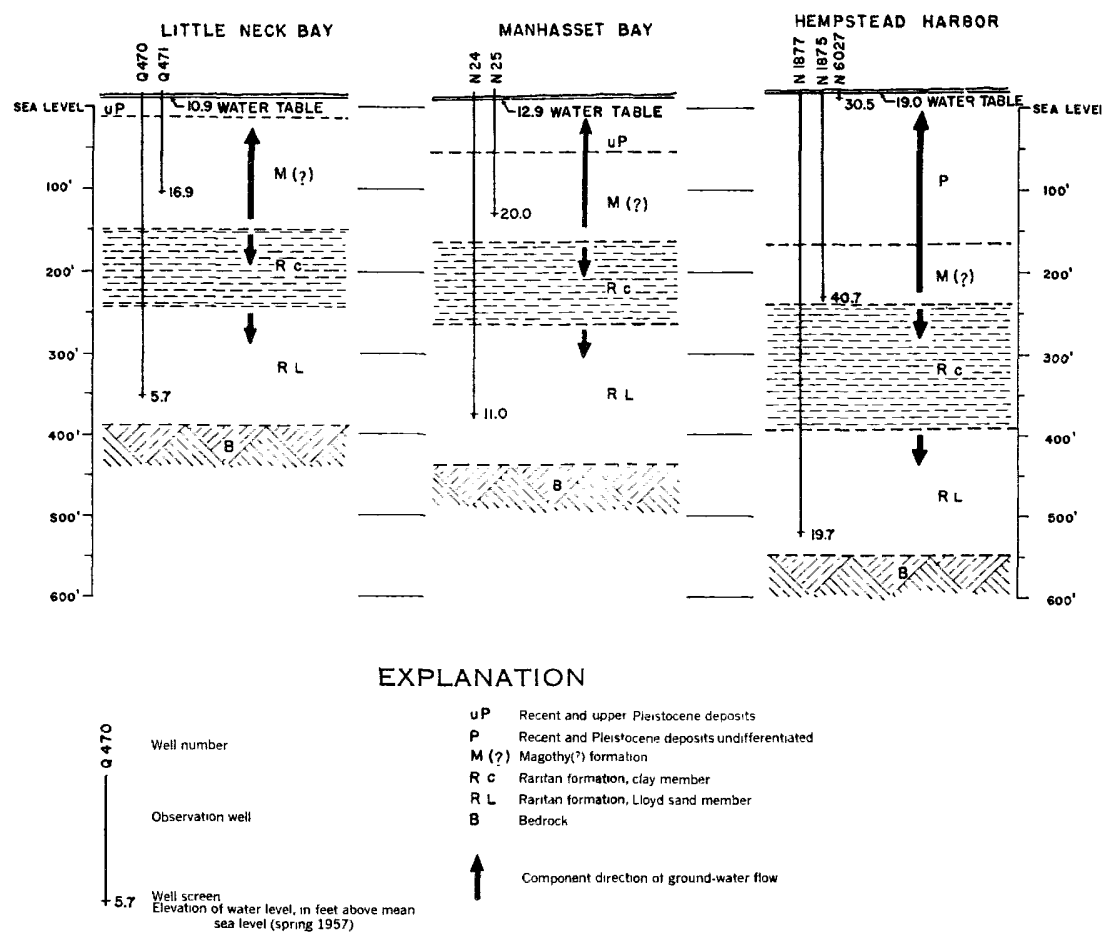

FIGURE 6.-Pressure relationships in shallow and deep wells at selected sites on Little Neck Bay, Manhasset Bay, and Hempstead Harbor, Long Island, N.Y. (1957).

sures in the principal aquifer, above the clay member of the Raritan formation, are generally 6 to 10 feet higher than the water table at corresponding sites. At the southern end of Hempstead Harbor, exceptionally high heads, resulting from recharge to the stre.ta above the clay member from the surrounding high ground, have been observed. At a depth of 12 feet below the land surface, pressures are 10 feet above the land surface, and at the base of the principal aquifer (260 feet below the land surface), pressures are about 20 feet above the surface (see fig. 6). 
Under natural conditions, the bulk of the water in the deep confined aquifer moves westward across the project area (pl. 11). However, a northerly component flows across Manhasset and Great Necks and Hempstead Harbor toward Long Island Sound. South of the northern limit of the principal aquifer (pl. 10), pressure heads in the deep confined aquifer are commonly from a few feet to as much as 50 feet lower than those in the principal aquifer and water moves downward. North of this limit, in the northern part of Manhasset and Great Necks, the water table in the shallow unconfined aquifer is generally 5 to 20 feet higher than pressure heads in the deep confined aquifer, and water moves downward from the shallow to the deep aquifer.

Movement of water in the vertical plane through the ground-water reservoir is demonstrated in a hydraulic profile from Sands Point to Garden City (pl. 12). This profile serves to indicate the relationships of the aquifers, chief confining strata (aquicludes), pressure heads, and principal areas of recharge and discharge. Water levels and piezometric heads are given as of April 1957 and reflect, where measured in supply wells, average recovery periods of 8 to 12 hours after pump shutdown. The line of the profile, shown on plate $9, w^{\text {'s }}$ chosen to show principal head relationships and flow directions in a typical vertical section through the ground-water reservoir. Inasmuch as flow directions in the shallow, principal, and deep aquifers do not coincide entirely in any one plane of section, some oblique-flow components are necessarily included and labeled as such. Also, the hydraulic profile shows the traces of equipotential surfaces where these are intersected by the line of profile.

\section{DISCHARGE}

Ground water is discharged naturally by evapotranspiration, coastal springs, submarine discharge into the salt-water bodies, and effluent seepage into streams that drain into Long Island Sound. Also, water is discharged artificially by withdrawals from wells.

Losses from the zone of saturation through evaporaticn and transpiration vary seasonally and depend in large degree on tl ${ }^{\circ}$ position of the water table with respect to the land surface. In areas where the water table is close to the land surface, moisture is returned to the atmosphere by evaporation from the soil zone and by the transpiration of plants whose roots tap the water table or the capillary fringe above it. Thus, high evapotranspiration rates prevail in some meadow lands, alluvial deposits, and swampy areas, particularly along the north shore and on Great and Manhasset Necks (see pl. 8). Evaporation from the land and from floating pans in the Mineola area, determined by the Surface Water Branch of the U.S. Geolorical Survey, ranged from 24.53 to 28.08 inches for 7 -month periods (April-October) 
in 1949,1950, and 1951, exceeding precipitation by about 1 to 4 inches during these periods (Brice, and others, 1959, p. 31).

Along approximately 42 miles of coastline in the area, springs at many places discharge at the edge of salt water and also $k$ slow sea level. Springs are particularly common in areas where Cretaceous Clay occurs above sea level, as on the east shore of Hempstead Harbor, north and south of Glen Cove. Discharge from individual springs, where it can be observed, is generally from 2 to $10 \mathrm{gpm}$, rarely more. From a survey it is estimated that the total discharge from springs along 42 miles of coastline may be as great as 2 to $3 \mathrm{mgd}$. Although no accurate estimate of its magnitude can be given, the bulk of this discharge presumably comes from the shallow unconfined aquifer. In addition, ground water is discharged offshore by upward leakage from the principal and deep unconfined aquifers. Discharge by submarine springs and seepage is undoubtly considerable.

Considerable quantities of ground water are discharged by effluent seepage into stream channels, where these intersect the water table. The total base flow of streams in the project area was estimated to average about $15 \mathrm{mgd}$ in 1957. The characteristics of the effluent streams of the project area are described more fully in the section on "Surface water."

Ground water is discharged artificially by withdrawals through punping or flowing wells. In 1957 withdrawal from wells for all purposes within the project area was about $40 \mathrm{mgd}$. Pumping by public-supply systems in the Nassau County part of the project area alone accounted for $30 \mathrm{mgd}$. Of the water withdrawn, it is estimated that sewage-disposal plants in the long established north-shore villages deliver 9 to $10 \mathrm{mgd}$ to the tidewater of Long Island Sound. In addition, the municipal sanitary-sewer systems of Mineola, Garden City, and parts of New Hyde Park are estimated to discharce 4 to 5 mgd, or possibly more, into the Nassau County trunk system that carries sewage to a treatment plant in Bay Park and ultimately to the ocean. The disposal of treated sewage at tidewater constitutes a net loss of about $15 \mathrm{mgd}$ from the report area. This loss will increase as Nassau County's Sewage Disposal District No. 2 is extended northward into New Hyde Park and Williston.

\section{WATER LEVEL FLUCTUATIONS}

Fluctuations of water levels in wells screened in the shallow unconfined aquifer generally reflect changes in ground-water storage, but those in wells screened in the principal and deep confined aquifers reflect changes in artesian pressure. Water levels in most shallow wells in Nassau County fluctuate from 1 to 4 feet per year as the result of variations in natural recharge and discharge. Normally, water levels decline as the growing season progresses, fror about 
May to November, and rise in response to ground-water replenishment during the winter and spring. A hydrograph of the average water level in 14 selected shallow wells in Nassau and Suffolk Counties, shown in figure 7, indicates seasonal fluctuations and long-term trends in response to precipitation. This hydrograph, representative of average ground-water conditions in the shallow unconfined aquifer, is compared with hydrographs of four shallow observation wells in the Mineola-New Hyde Park area (fig. 7). Deficient precipitation during 1956-57 is shown by unusually low water levels in all wells at the end of 1957. However, the average water level in the 14 shallow wells returned nearly to normal during 1958, whereas the water level in wells N1104, N1125, and N1138 had only partially recovered during that time. It appears likely that the water table is declining in the densely built-up areas represented by these wells-possibly as a result of increased pumping or loss of former sources of recharge occasioned by the expansion of centralized sewage-disposal systems that discharge effluent directly to the sea rather than into the ground. However, the period of the observed decline is as yet too short to draw definite conclusions. Declining water levels are noted also in the hydrograph of observation well N1479, in Great N'eck (fig. 8). An overall decline of about 3 to 4 feet since 1949 is attributed to industrial pumpage $1 / 2$ to 1 mile south of the well. Te decline of water levels in this instance is aggravated by the diffusion of spent cooling water through wells that are screened above perching strata, whereas the withdrawals are made from deeper zones in the shallow unconfined aquifer. Much of the returned water in this s rea probably discharges directly to Little Neck Bay without reaching the main water table.

The normal seasonal trend of declining water levels in the shallow aquifer during the summer may be reversed by exceptionally heavy rainfall, as, for example, during the hurricanes of August, 1955. For that month a total of 15.73 inches of rain was recorded at Mineola, with 12.78 inches falling in the period August 11-14. An almost instantaneous and sustained recovery of water levels is noted not only in most of the water-table wells but also in wells screened in the shallower artesian zones of the principal aquifer (N2635, from continuous water-stage recorder, fig. 8).

The daily water-level record during 1955 and 1956 of two observation wells screened in the deep confined aquifer, N5530 in Port Washington and N4266 in Great Neck, is shown in figure 9. Poth observation wells indicate pressure trends in the deep confined aquifer in the two peninsulas, even though there are daily fluctuations of several feet which represent interference by public-supply well N3443 in Great Neck and wells N1715, N1716, and N4859 in Port Washington. 


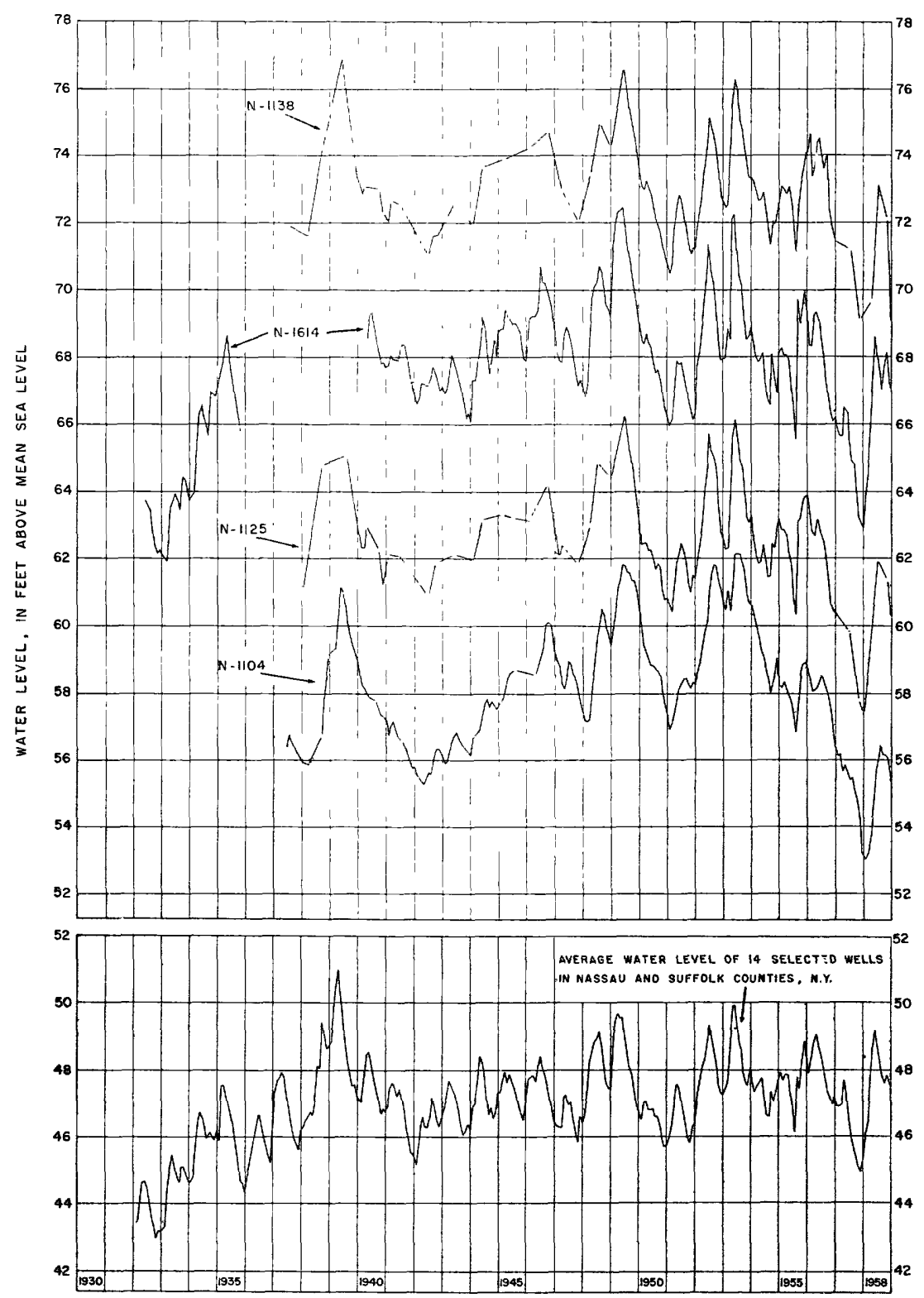

FiguRe 7.-Hydrograph of 4 water-table observation wells in Mineola-New Hyde Park area, compared with average water level of 14 selected shallow wells in Nassau and Suffolk.Counties, N.Y. 


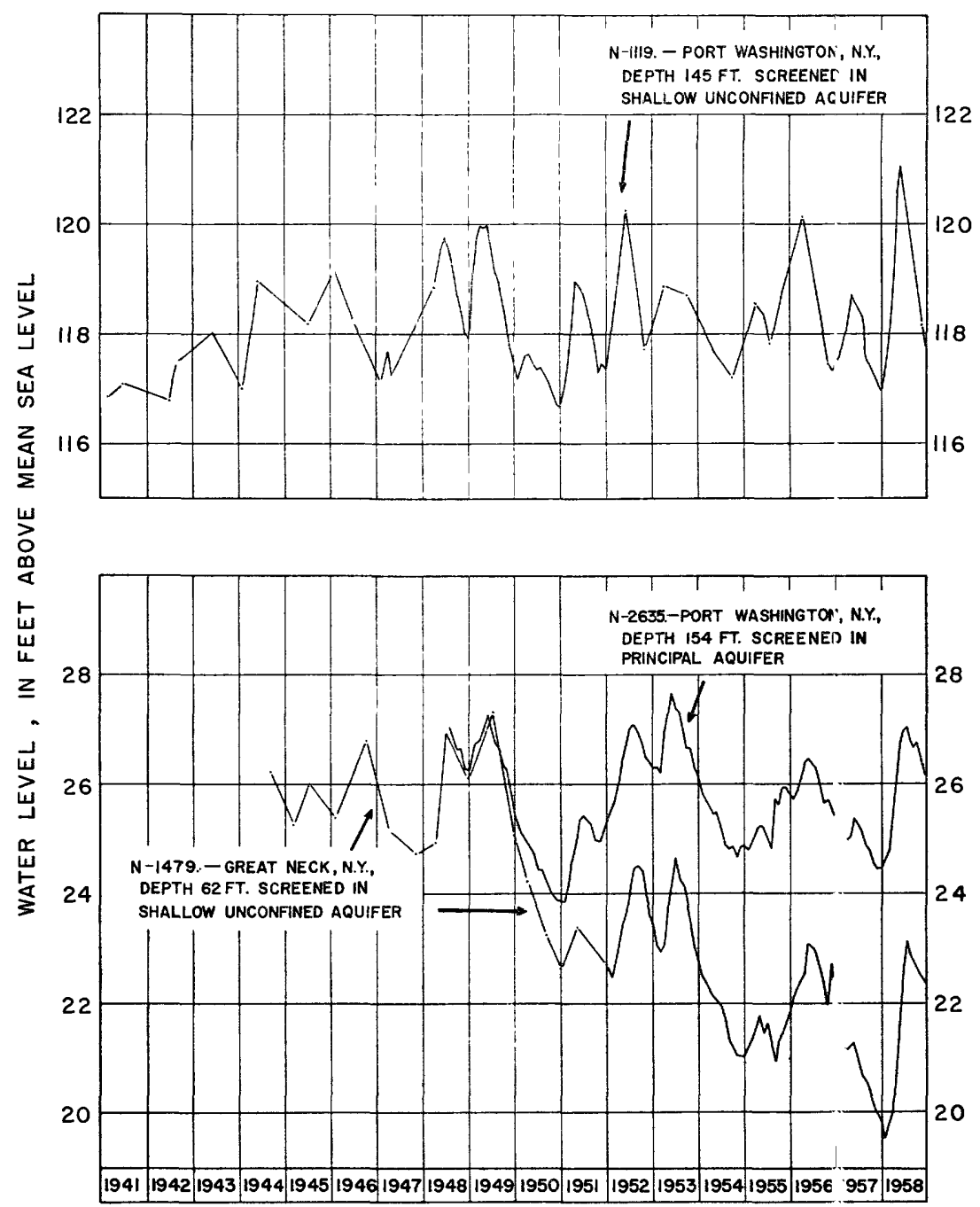

FIGURE 8.-Hydrograph of observation wells N1119 and N2635 in Port Washingtor and N1479 in Great Neck, N.Y.

A long-term hydrograph of observation well Q470, also screened in the deep confined aquifer, is shown in figure 10 .

Artesian pressures in the deep confined aquifer have declined during the past 50 years as the result of long-continued fumping in central Queens and also in the project area. In the Lake Success area, Veatch (1906) reports water levels of about 37 feet above mean sea level in a well (N263, Veatch No. 317) screened in the Lloyd sand member. Artesian pressures in the aquifer at that site were $690-186-63-4$ 

HYDROGEOLOGY OF NASSAU AND QUEENS COUNTIES, N.Y.

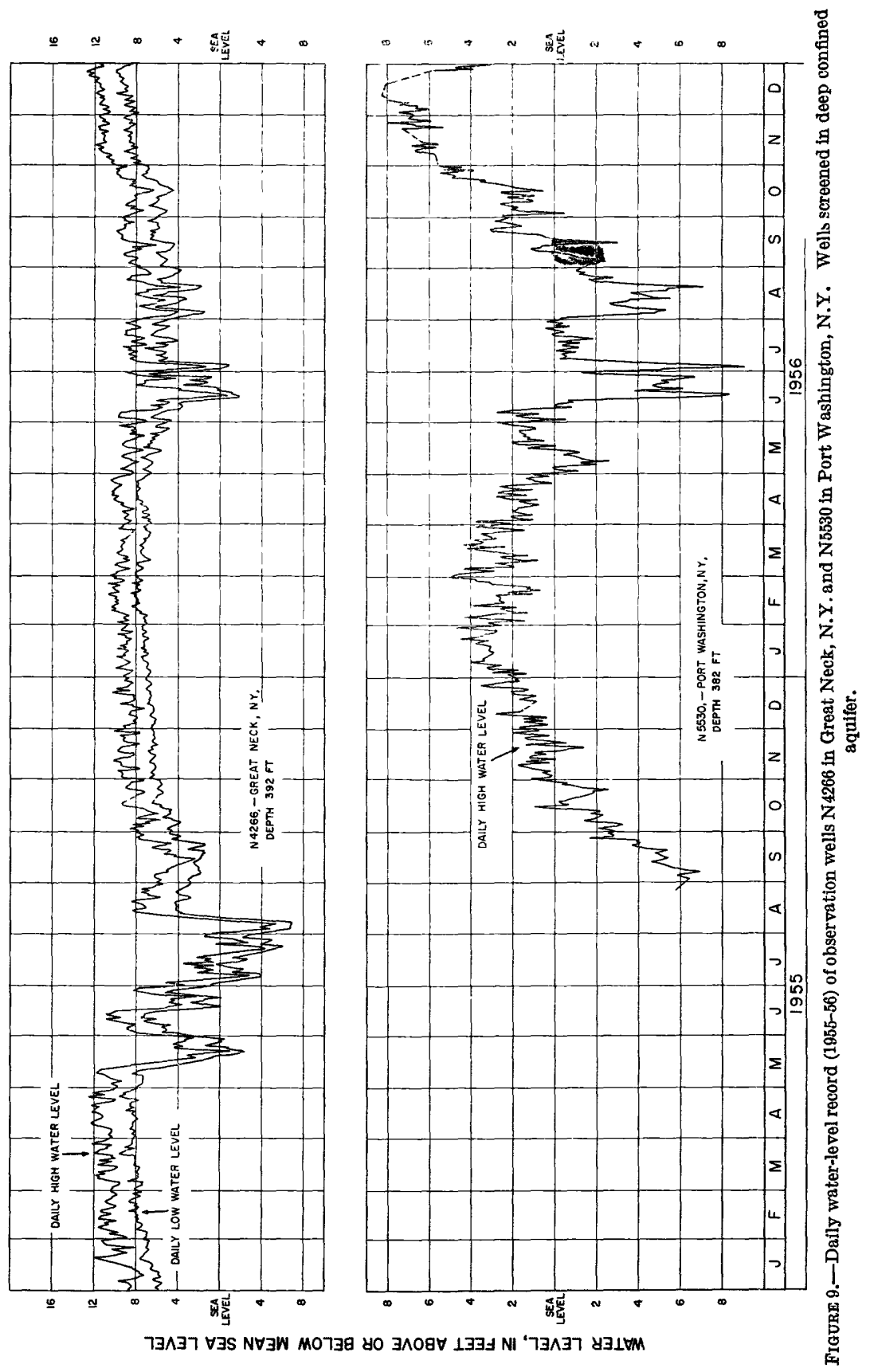




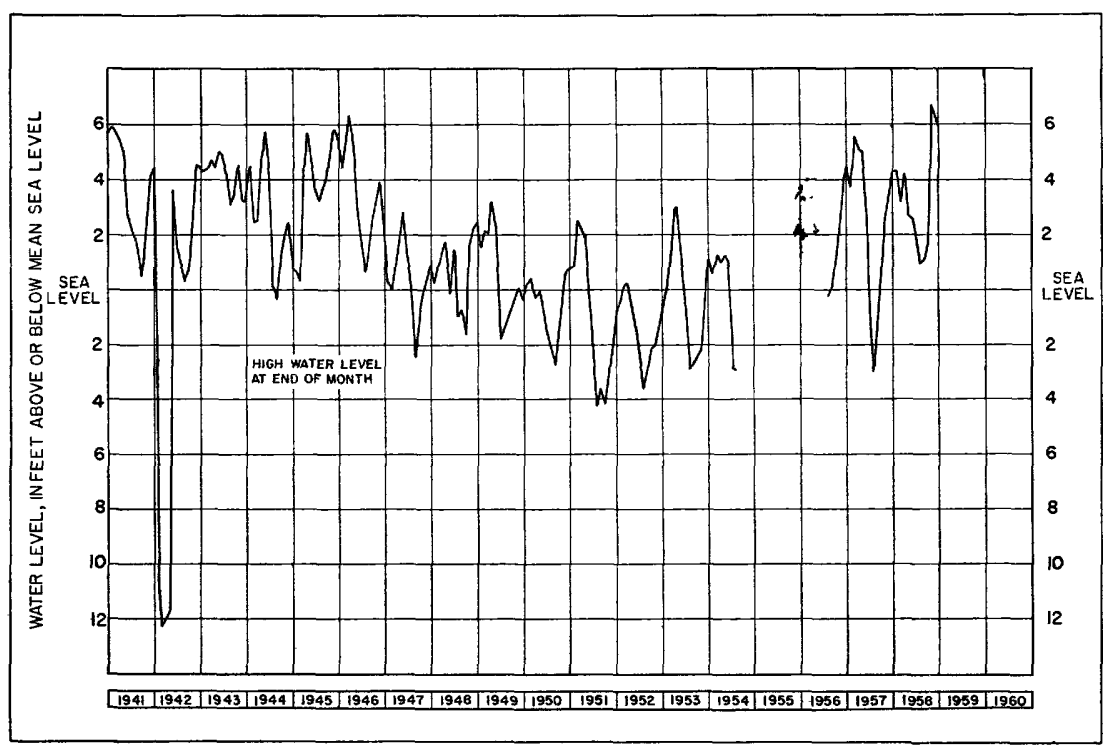

FIGURE 10.-Hydrograph of observation well Q470, depth 375 feet, screened in the deep confined aquifer (1941-58).

about 10 to 12 feet above sea level in 1957, indicating a lowering of artesian pressure of at least 25 feet since 1903. It is interesting to note that the position of the water table in 1903, as roported by Veatch for the same well site (N263), was also the same in 1957. In 1903 a head difference of 19 feet between the water table and the Lloyd sand member existed at the site of N263, which probably represented natural conditions. As in this area, the lower head in the Lloyd sand member is due to friction losses of downw?rd moving water.

Pressure heads in the principal and deep confined aquifers are also subject to cyclical fluctuations produced by changes in loading of the confining strata. Thus daily or longer term changes in barometric pressure may be accompanied by water-level changes of 0.1 to 0.2 foot, or even more. Typical examples of such fluctuations have been observed in wells N5210, N5918, N6282 (table 11). Some wells show fluctuations of water level in response to ocean tide according to distance from shore, degree of confinement, and well construction. Tidal fluctuations are commonly between a few tenths of a foot and about 2 feet. They have been observed in wells N657, N662, N687, $\mathrm{N} 5679$, and many others. Other minor variations of the water level in artesian wells, on the order of a few hundredths of a foot, may be due to earth tides, earthquake, the passing of railroad trains, and other causes. Such fluctuations in wells in the project area generally are masked by fluctuations of large magnitude. 
Pumping effects are transmitted over much greater distances in artesian aquifers than in water-table aquifers. Thus, observed piezometric heads reflect withdrawals from wells both within and beyond the project area. The wells in the deep confined aquifer may reflect the composite effects of pumping at centers as far as 10 miles from the project area (See Q470, fig. 10; N4266 and N5530, fig. 9). On the other hand, pumping wells tapping the shallow unconfined aquifer and the upper part of the principal aquifer do not generally produce significant effects beyond a half-mile radius from the pumping centers.

The water-level record of selected observation and other wells is given in table 13. All measurements were made by personnel of the U.S. Geological Survey or the Nassau County Department of Public Works. Measurements in public-supply wells were obtained after recovery periods of 8 hours or longer. Single water-level measurements are included in table 11.

\section{PUMPage}

Ground water is obtained by means of drilled wells tapping the three aquifers that have been described previously. Municipal or privately owned public-supply systems pump ground water exclusively to supply the villages of northwestern Nassau County, whereas water supplies in Queens County are derived partly from local underground sources and partly from the upstate reservoirs of N'ew York City. Large quantities of ground water also are pumped in the project area for cooling and various industrial purposes. Although installations in this category generally are widely scattered and commonly pump only 5 to 20 million gallons per year each, there are 4 major centers of concentrated pumpage, shown in figure 11 and listed as follows:

Industrial pumpage, 1957

$(m g d)$

1. Glen Cove

0. 5

2. Glenwood Landing 6

3. Creedmoor State Hospital

4. Lake Success.

*Institutional pumpage.

Withdrawals in areas 1, 2, and 3 are from the Lloyd sand member of the Raritan formation (deep confined aquifer), whereas the withdrawal in Lake Success (area 4) is from Pleistocene and Magothy(?) (principal aquifer) sources. About 75 to 85 percent of the water pumped for industrial and cooling purposes is returned to the groundwater reservoir by diffusion wells and sumps. 


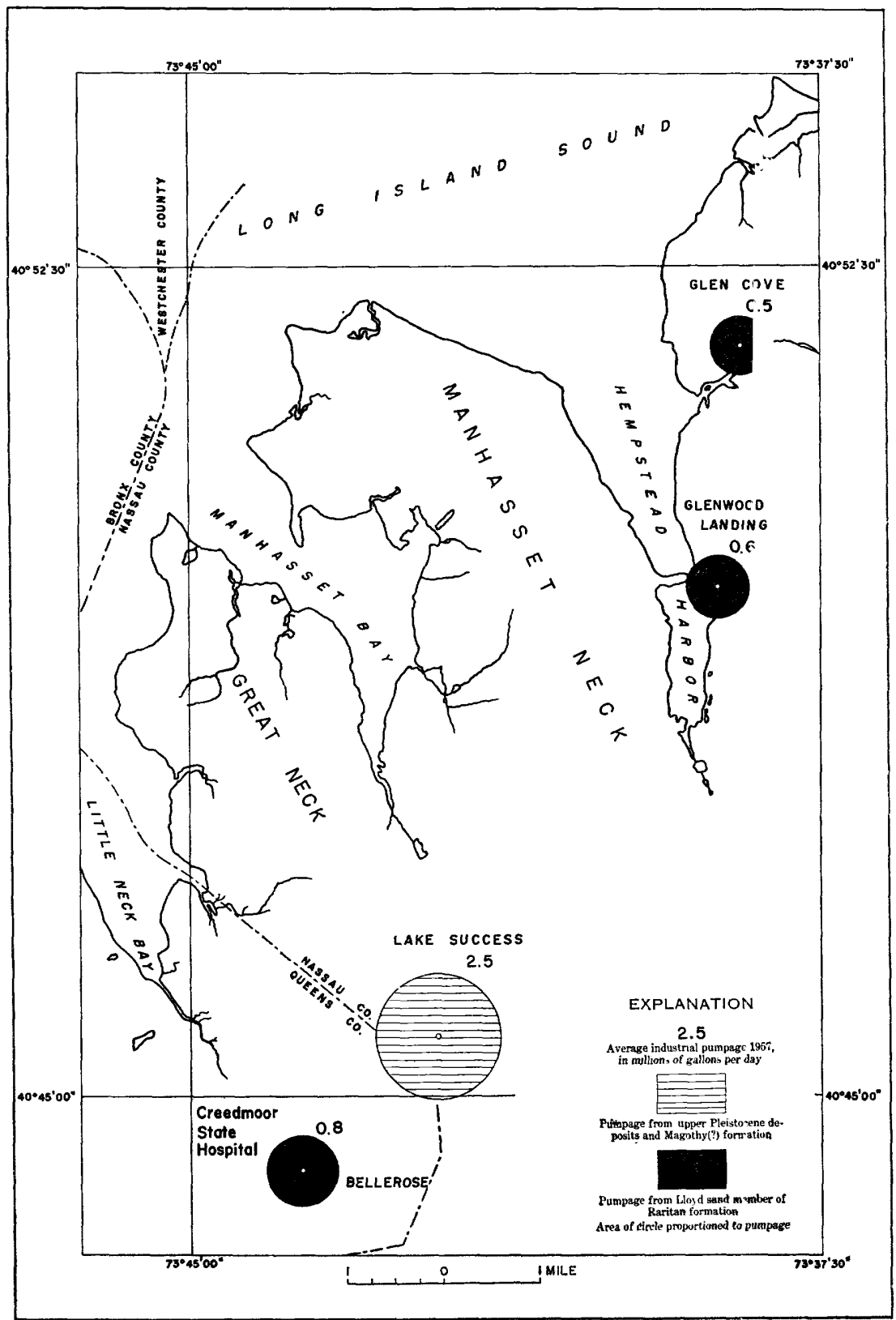

Fraune 11.-Map of northwestern Nassau and northeastern Queens Counties, N.Y., sh Jwing distribution of major centers of industrial pumpage (1957). 
Gross withdrawal of ground water for all purposes in the project area was about $40 \mathrm{mgd}$ in 1957, as follows:

Public supply

Million gallons per day

Private supply, estimated

30. 3

Sprinkling and irrigation supply, estimated

Institutional supply, estimated.

Industrial and cooling supply, estimated.

The listed total of $30.3 \mathrm{mgd}$ for public supply represents pumpage in northwestern Nassau County, with the exception of $0.3 \mathrm{mrd}$ in the Queens part of the project area. However, large withdrawals of ground water for public supplies are being made in Queens County, beyond the southwestern limit of the project area. Ground-water pumpage for public supply in northwestern Nassau County since 1930 is shown in table 7, which summarizes yearly pumpage from all aquifers by Water Districts and water-supply companies in the area. The increase of $4.5 \mathrm{mgd}$ from 1956 to 1957 is partly due to abnormally low precipitation during 1957. About $21.5 \mathrm{mgd}$ or 72 percent of the total water pumped in 1957 for public supply were derived from Magothy(?) and Pleistocene sources within the principal aquifer; the other aquifers contributed a minor share, as follows:

Public Supply Systems Northwestern Nassau County, 1957

(mgd)

Shallow unconfined aquifer. 40

Principal aquifer. 21.5

Deep confined aquifer

Total 30.0

TABLE 7.-Ground-water pumpage for public water supply in northweste"n Nassau County, N.Y. $(1930,1940,1950,1956,1957)$

[Yearly pumpage from all sources, in thousands of gallons]

\begin{tabular}{|c|c|c|c|c|c|}
\hline Locality & 1930 & 1940 & 1950 & 1956 & 1957 \\
\hline $\begin{array}{l}\text { Manhasset-Lakeville Water District } \\
\text { Village of Garden Oity }{ }^{\prime} \\
\text { Oitizens' Water Supply } \\
\text { Newtown. } \\
\text { Jamaica Water Supply Company } \\
\text { Roslyn Water District } 1 \\
\text { Port Washington Water District. } \\
\text { Oity of Glen Cove } 1 \\
\text { Village of Mineola } 1 \\
\text { Garden Oity Park Water District } \\
\text { Albertson Water District } \\
\text { Village of Williston Park } \\
\text { Sea Cliff Water Company } \\
\text { Village of Sands Point } \\
\text { Village of Plandome. }\end{array}$ & $\begin{array}{r}300,885 \\
492,056 \\
404,466 \\
293,387 \\
215,392 \\
277,250 \\
256,564 \\
182,500 \\
89,334 \\
245,278 \\
\\
\\
\end{array}$ & $\begin{array}{r}585,414 \\
453,878 \\
544,252 \\
205,918 \\
242.070 \\
372,540 \\
243,273 \\
335,782 \\
55,614 \\
168,873 \\
299,917 \\
56,620 \\
30,717\end{array}$ & $\begin{array}{r}1,177,003 \\
596,593 \\
648,605 \\
1,355,550 \\
450,851 \\
455,810 \\
349,787 \\
518,474 \\
269,812 \\
402,727 \\
216,867 \\
48,863 \\
37,642\end{array}$ & $\begin{array}{r}1,641,100 \\
1,194,798 \\
1,107,154 \\
973,700 \\
719,980 \\
743,960 \\
757,754 \\
665,151 \\
468,585 \\
321,497 \\
275,231 \\
282,496 \\
127,884 \\
50,097\end{array}$ & $\begin{array}{r}1,889,711 \\
1,409,187 \\
1,308,447 \\
1,084,500 \\
895,630 \\
876,980 \\
847,990 \\
775,283 \\
586,675 \\
436.560 \\
319,086 \\
294,882 \\
181,951 \\
77,909\end{array}$ \\
\hline Total_-_. & $\begin{array}{c}2,757,112 \\
\text { or } \\
7.6 \mathrm{mgd}\end{array}$ & $\begin{array}{c}3,594,868 \\
\text { or } \\
9.8 \mathrm{mgd}\end{array}$ & $\begin{array}{c}6,528,584 \\
\text { or } \\
17.9 \mathrm{mgd}\end{array}$ & $\begin{array}{l}9,329,387 \\
\text { or } \\
25.5 \mathrm{mgd}\end{array}$ & $\begin{array}{l}10,954,791 \\
\text { or } \\
30.01 \mathrm{mgd}\end{array}$ \\
\hline
\end{tabular}

1 Total includes pumpage from wells beyond limits of project area. 
The areal distribution of pumpage for public supply is shown on plate 13, which also indicates individual pumping installetions and the formations from which withdrawals are made. The map is based on average daily pumpage rates during July 1955 when vithdrawal was exceptionally heavy, more than $52 \mathrm{mgd}$ in the area. This total amount includes $4.26 \mathrm{mgd}$ pumped by the City of New T.Tork from the Douglaston well field.

\section{TEMPERATURE}

Ground-water temperatures of $54^{\circ}$ or $55^{\circ} \mathrm{F}$ are commonly observed in wells screened at intermediate depth (200 to 400 feet) in the project area. These temperatures, uniform throughout the year, are $2^{\circ}$ to $3^{\circ} \mathrm{F}$ warmer than the annual average air temperature $\left(52.7^{\circ} \mathrm{F}\right)$. Ground-water temperatures at very shallow depth are inflienced by air temperatures and may range seasonally from about $45^{\circ}$ to $65^{\circ} \mathrm{F}$. However, at depths of about 50 feet, the effect of surface temperatures already is reduced greatly, and ground-water temperatures usually do not fluctuate more than $6^{\circ} \mathrm{F}$ annually. Water temperatures in the deepest wells in the area, screened 600 to 700 feet below the land surface, are usually $58^{\circ}$ or $59^{\circ} \mathrm{F}$. In general, ground-wate- temperatures in all aquifers are sufficiently low to meet industrial cooling and other air-conditioning requirements. No rise in grcind-water temperatures due to the diffusion of spent cooling water, as in parts of Queens County, has been observed in the project area. Temperature measurements are given in the "Remarks" column of table 11.

\section{CHEMICaI quatirty}

In general, ground water in all aquifers in the area is cf excellent quality and suitable for domestic and industrial purposes. Except for isolated instances of contamination by salt water, the mineral content of water from shallow wells is usually less thar $150 \mathrm{ppm}$ (parts per million) of dissolved solids. In many of the deeper wells the dissolved-solids content is only 30 to $60 \mathrm{ppm}$. The lardness of the water ranges from $8 \mathrm{ppm}$ to $134 \mathrm{ppm}$, as $\mathrm{CaCO}_{3}$, which is classified as very soft to only moderately hard. This water is not sufficiently hard to interfere with its use for most purposes or to cause much public demand for water softening. The water is generally slightly acid, $\mathrm{pH}$ determinations of 6.2 to 6.9 being common. Lower $\mathrm{pH}$ factors, from 5.3 to 5.6 , have been determined for water from a few shallow and deep wells. Chemical analyses of water frcm selected wells are given in table 14, including 19 complete analyses by the U.S. Geological Survey. The diagrammatic plot of tha principal anions and cations determined in 18 analyses (fig. 12) shows the rather uniform character of ground water in all aquifers, except from 2 wells which had evidence of contamination (N15, N662). 


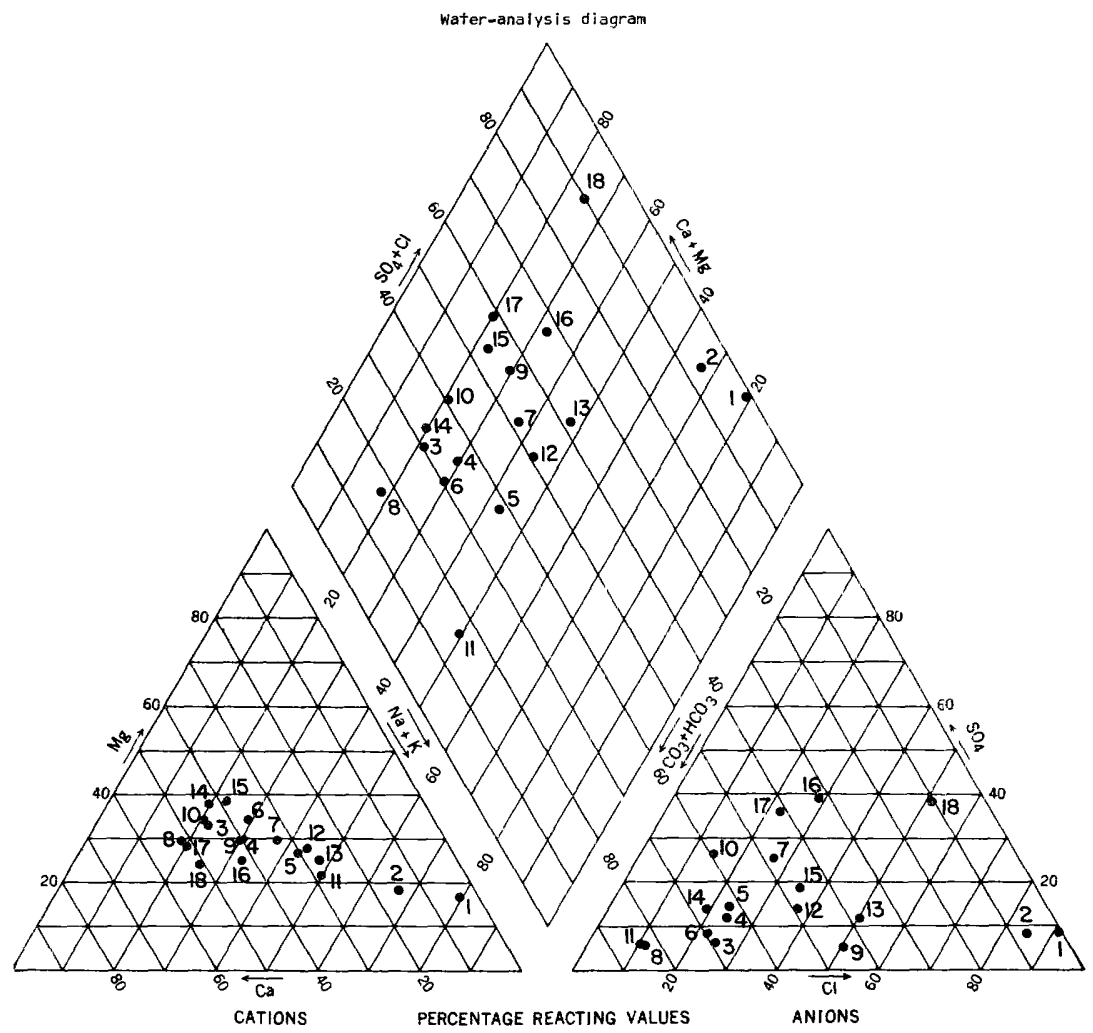

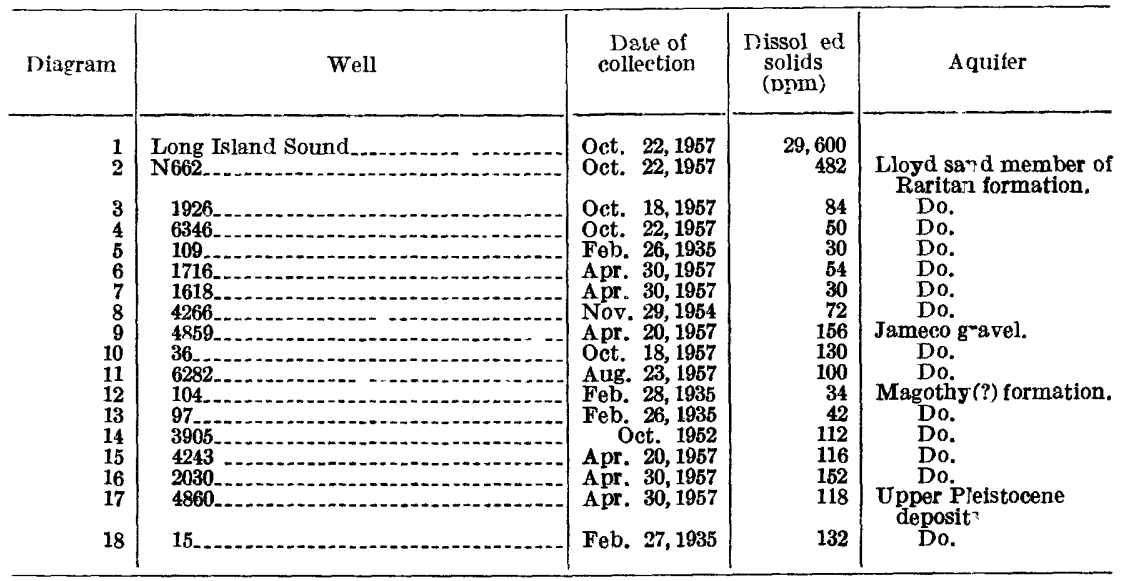

FIGURE 12.-Diagram showing chemical character of ground water from four source format'ons in northwestern Nassau County, N.Y. 
The iron content of the water from several wells (table 14) ranges from 0.35 to $6.0 \mathrm{ppm}$ which exceeds the maximum of $0.3 \mathrm{ppm}$ combined iron and manganese content as recommended by the U.S. Public Heatlh Service drinking water standards for use on common carriers (U.S. Public Health Service, 1946). High iron content is commonly associated with wells that are screened in the Lloyd sand member of the Raritan formation or in the Jameco gravel. Water of high iron or manganese content may require treatment for domestic or other use.

\section{CONTAMINATION}

The chloride and nitrate content of water from some wells in the area exceeds the normal content of $6 \mathrm{ppm}$ of chloride and less than $3 \mathrm{ppm}$ of nitrate, as listed in table 14. The high contert of these constituents may be indicative of contamination. In areas distant from the shoreline, sources of ground-water contamination by nitrates and chlorides are domestic and industrial wastes, fertilize"s, sodium and calcium chloride used in road maintenance, and others. Nitrate content of $12 \mathrm{ppm}$ or more has been determined in water from several wells (N15, N2030, and others, table 14). These wells rre located in the densely populated areas of New Hyde Park, Port Washington, and Mineola. Nitrate content of $14 \mathrm{ppm}$ occurs in water from comparatively deep wells (N578 and N3185, table 14) in Minoola which are screened 400 to 461 feet below the land surface. A publicsupply well in the Lake Success area (N4243, table 14) shows nitrate content increased from $6.6 \mathrm{ppm}$ in 1954 to $13 \mathrm{ppm}$ in 1957 at a screened depth of about 250 feet. Relatively high chloride content of 19 and $54 \mathrm{ppm}$ was determined in 1957 in two shallow wells (N91, N93) located in Garden City. It seems likely that contamination of shallow ground water by organic wastes or fertilizers is responsible for the increase of nitrate and chloride content. The downward component of ground-water flow makes it possible for contanination in the shallow ground water to move into the deeper aquifers in these inland areas. Single chloride determinations are included in table 11. Additional chloride data of water from selected wells aro found in table 15.

Two sources of contamination in near-shore areas are: (1) artificial ponds containing salt water pumped from the bays and (2) sea-water enroachment into the aquifers adjacent to the shorelines. On Manhasset Neck in 1957, four settling ponds were used in sand- and gravelwashing operations, each containing salt water of about $14,000 \mathrm{ppm}$ of chloride. Although these ponds were only $1 / 2$ to 1 acee in area, downward leakage of the salt water from elevations of about 20 to 50 feet above sea level has contaminated several wells downgradient from the ponds. Chloride content of several hundred parts per million 
or more was determined in water from shallow and deep wells along the west shore of Hempstead Harbor (N6160, N3458, table 11; N657, N662, table 15). A brackish ground-water zone is indicated by analyses of water from two wells, N1941 and a test well at the site of N6346, about half a mile west of Bar Beach. Both wells are screened a few feet below sea level. A water sample taken at well N1941 in 1943 had 2,150 ppm of chloride; in 1957, waten from the test well at the site of $\mathrm{N} 6346$ had a chloride content of $2,550 \mathrm{ppm}$. Both wells are north and east of present and former salt-water settling ponds, which apparently are the source of contamination at the well sites and Bar Beach. An increase in chloride content from $10 \mathrm{ppm}$ in 1956 to $45 \mathrm{ppm}$ in 1957 also was noted in samples from rell N3311 (table 15), screened in sand of the Magothy(?) formation at about 140 feet below sea level. In the Port Washington area, a salt-water settling pond formerly located about 1,000 feet north of Sandy Hollow Road probably caused abnormally high chloride concentations, as much as $220 \mathrm{ppm}$, in several wells at a depth of 60 to 90 feet (N819 to N823). In 1956, water from a flowing observation well (N1483) close to another salt-water settling pond had a chloride content of $5,500 \mathrm{ppm}$.

A change in the position of the contact, or interface, bet-reen fresh and salt water can result in chloride contamination of we'ls by seawater encroachment in coastal areas. In water-table aquifers, the interface is at or near the shore, but in artesian aquifers, tr 9 pressure heads commonly are sufficiently high to maintain the interface some distance offshore. However, under either water-table or artesian conditions, sea-water may encroach if the natural seaward gradients of ground-water flow are reversed by pumping from wells near the shore. If any part of the cone of depression of a pumping center extends seaward to the vicinity of a salt-water body, salty water may be drawn toward the pumping wells.

A major cone of depression in the Port Washington area (pl. 11) is conducive to sea-water encroachment. The cone of depression in the piezometric surface of the deep confined aquifer is the result of pumping since 1942 from two wells (N1715 and N1716) screened in the Lloyd sand member of the Raritan formation. W'ithdrawal from these wells from 1950 to 1957 averaged $0.8 \mathrm{mgd}$ and occasionally reached $1.5 \mathrm{mgd}$. The water level of observation well $\mathrm{N}^{\top} 5530$ (see fig. 9) was strongly affected by pumping from wells N1715 and N1716, 0.75 mile to the southeast. Interference from the same pumping center also was observed at N675, near Manhasset Bay.

The elongation (pl. 11) of the cone of depression northwest of the pumping center, at a time when no other significant withdrawals from the aquifer were being made, is attributed to the relative im- 
permeability of almost the entire sequence of sediments above the clay member of the Raritan formation in that direction. Northwest of the pumping center, these strata consist largely of the Gardiners clay, lacustrine(?) clay, and till. (See $\log$ of N5530, tab ${ }^{1}$ 12; also logs of N1291 and N1581 given in Roberts and Brasherrs, 1946.) Although the areal extent of the cone of depression surro'unding the pumping center (N1715, N1716) can be defined only in on direction by existing wells (pl. 11), it is inferred that hydraulic gracients from Manhasset Bay toward the pumping center, which is about 1 mile from the shore, also existed during the greater part of each year under conditions prevailing in 1942-59.

Contamination by sea-water encroachment was noted in 1944 at the public-supply installation near Sandy Hollow Road in Port Washington. Chloride content of $700 \mathrm{ppm}$ was determined in July 1944 in a sample from well N35, a deep well screened in the Jameco gravel. This well is about 1,000 feet east of Manhasset. Bay and is the closest well to the shore within the well field. However, this well was abandoned in 1946 and is used only as an obserration well. Pumping from about 10 shallow and deep wells in the field increased considerably after 1934 and averaged $0.99 \mathrm{mgd}$ from 1935-44. Until 1941 the well field at Sandy Hollow Road was the only source of public water supplies for Port Washington (fig. 13). Although withdrawals were reduced after 1944, chloride concentrations in well N35 increased from $700 \mathrm{ppm}$ in 1944 to $1,150 \mathrm{ppm}$ in Januar. 1946. A gradual increase of chloride content also was noted in samples from three other deep wells in the field, N824, N825, N826. After the well field was abandoned in November 1955, comparatively small withdrawals were made from one shallow (N4860) and one deep well (N4859). The deep well is screened in the Jameco gr'vel within the deep confined aquifer. This well, about 350 feet east of the most landward of the abandoned wells, is near the present salt-water front. The chloride concentration in water from N4859 increased from $6 \mathrm{ppm}$ in April 1956, when the well was installed, to $56 \mathrm{ppm}$ in August 1957 (table 15).

Small seasonal increases (10 to $30 \mathrm{ppm}$ ) in chloride concentration have also been observed in some wells in shore areas that are screened in the Lloyd sand member of the Raritan formation. "?hese wells are in areas where substantial daily withdrawals of ground water have been made for many years and where the equilibrium between fresh and salt water may be disturbed by any increase in pumping rates. Whereas the normal chloride content of water from the Lloyd sand member is 3 to $6 \mathrm{ppm}$, chloride concentrations of $36 \mathrm{ppm}$ have been observed in a sample from well N2424 in Glenwoot Landing, 


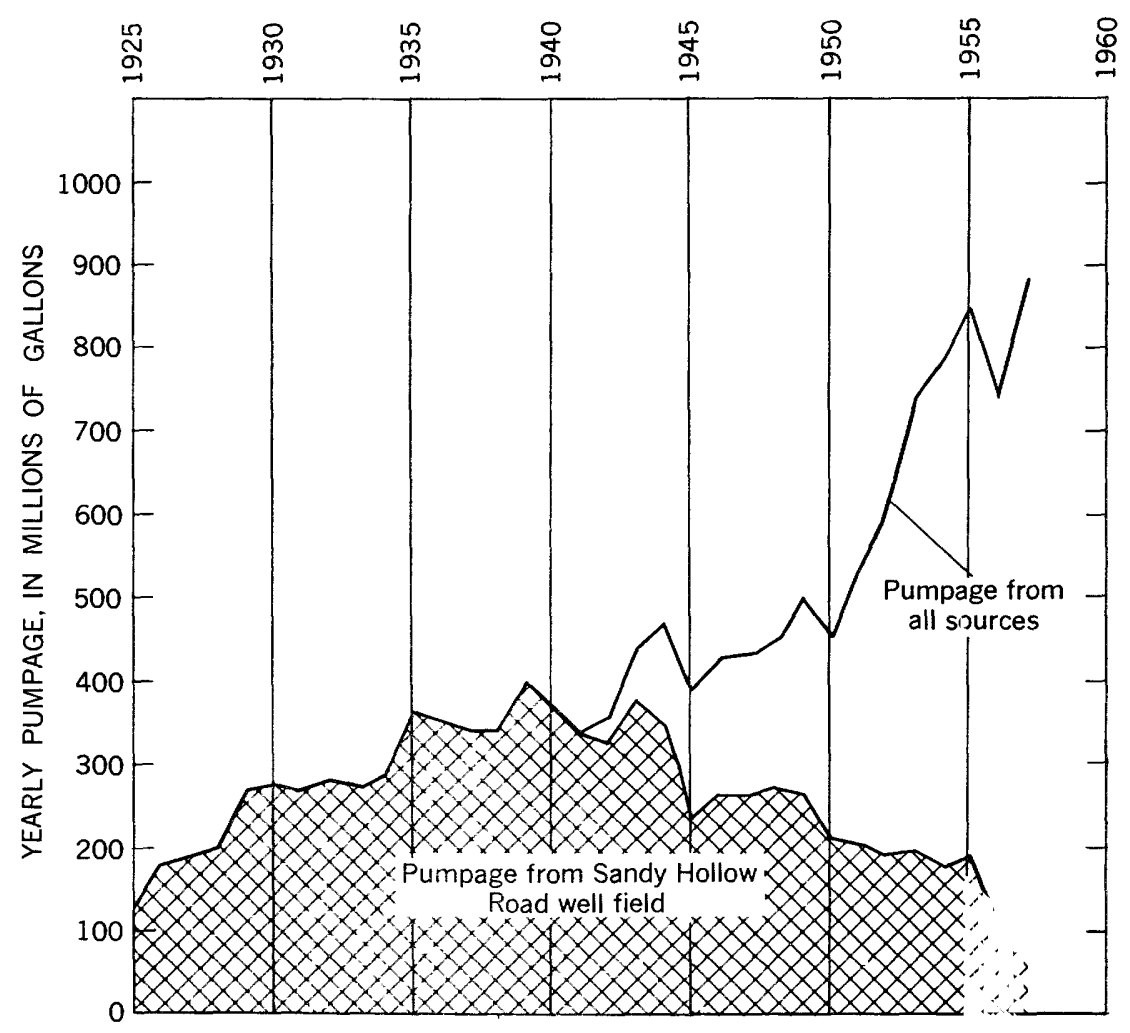

Figure 13.-Diagram showing yearly total pumpage by Port Washington Water District and withdrawals from well fiald at Sandy Hollow Road, Port Washington, N.Y. (1925-57).

$13 \mathrm{ppm}$ at N1926 in Kings Point, and $15 \mathrm{ppm}$ at N906 in Sea Cliff (tables 14 and 15).

\section{SURFACE WATER}

The surface-water bodies of the project area, a few small streams, some ponds, and large bodies of salt water connected with Long Island Sound, are treated briefly. The following discussions are restricted to streamflow characteristics and to the chemical quality and temperature of surface-water bodies that are related to the ground-water features of the area.

\section{STREAMFLOW CHARACTERISTIOS}

Inasmuch as the major drainage divide, the Harbor Hill terminal moraine, is close to the north shore in the project area, the streams discharging into Long Island Sound have short courses, usually less than 3 miles. The bulk of the streamflow represents ground-water discharge in the lower reaches of valleys where the water te.ble intersects the land surface. Base flow of the larger streams discharging 
into Hempstead Harbor, Manhasset Bay, Little Neck Bay, and Long Island Sound is generally less than 3 efs (cubic feet p?r second; $1 \mathrm{cfs}=646,317 \mathrm{gpd}$ ). Gaging-station records generally show that the streams have a large degree of uniformity of base flow throughout the year. However, they also show short-term peaks in flow due to overland runoff after storms and long-term fluctuations due to seasonal changes in ground-water storage. The only stream in northwestern Nassau County whose discharge is being gaged by a continuous water-stage recorder is Cedar Swamp Creek. T is stream is considerably larger than the others in the area, as it has an average discharge of $7.40 \mathrm{cfs}$ for the period of record (1938-55). Its course of about 4 miles follows a relatively broad north-south valley from Greenvale to Glen Cove, where it turns westward toward Hempstead Harbor. Streamflow is sustained by perched ground water and ponds in the Greenvale and Glen Head area. However, effluent seepage from the main ground-water body increases the discharre of the stream considerably in its lower reaches near Glen Cove. Daily discharge of Cedar Swamp Creek, from records of the Surface Water Branch of the U.S. Geological Survey, has been reported by R. M. Sawyer (1958). In the same report, the author discusses precipitationrunoff relationships and other factors affecting streamflow in Nassau County.

A summary of discharge measurements of the larger coastal streams within the project area is presented in table 8 . All measurements were made by the Surface Water Branch; the location of gaging stations is shown in figure 14. Although the discharge measurements given in table 8 are only partial, they are representative of the relative rank of the north-shore streams. One of the major tributaries to Leeds Pond, the Plandome-Port Washington drain, was gaged at two stations (G and H, fig. 14) on December 28, 1956. In a distance of 3,200 feet, streamflow increased from 0.31 to $0.69 \mathrm{cfs}$ (table 8); the increment represents lateral ground-water flow from the east.

In addition to the streams that have been gaged, there are a few smaller creeks, some of intermittent flow, where the discherge is estimated to range from about 0.2 to $0.5 \mathrm{cfs}$. The combined runoff by gaged and ungaged streams within the project area in 1957 was estimated to be $23 \mathrm{cfs}$, or $15 \mathrm{mgd}$.

\section{CHEMICAL QUALITY AND TEMPERATURE}

The salinity of waters from Long Island Sound bays, and harbors varies considerably according to season and location of sampling: points. Salinity and temperature data for several tide stations on Long Island Sound are given in Special Publication nos. 278 and 279 of the U.S. Department of Commerce, Coast and Geodetic Survev. 


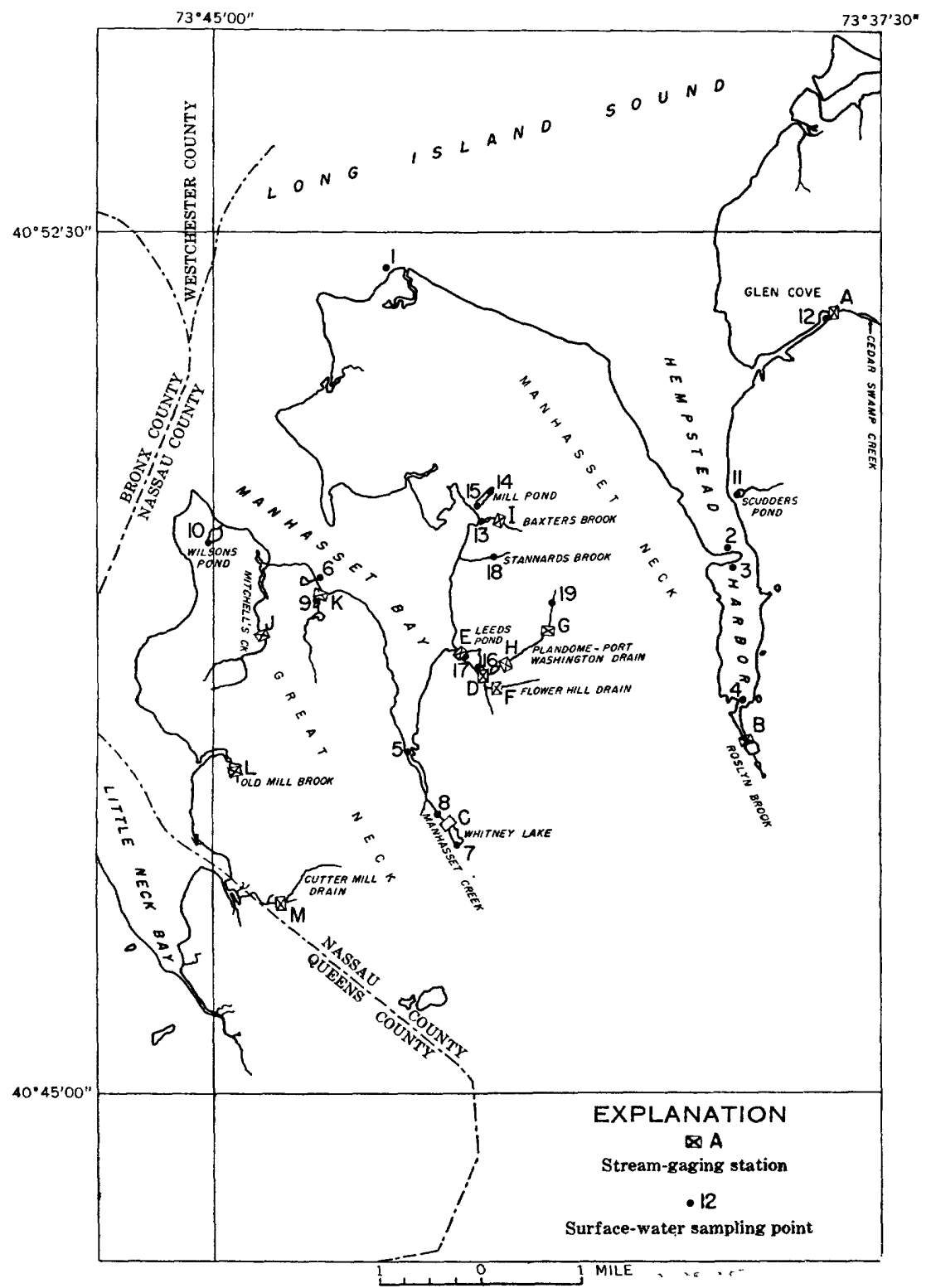

FIaURE 14.-Map showing location of stream-gaging stations and surface-water sampling points. 
TABLE 8-Stream-discharge measurements in northwestern Nassau County, N.Y.

[Measurements by Surface Water Branch, U.S. Geol. Survey]

\begin{tabular}{|c|c|c|c|}
\hline $\begin{array}{l}\text { Location } \\
\text { (fig. 14) }\end{array}$ & Stream & Type of record & $\begin{array}{l}\text { Discharge } \\
\text { (cfs) }\end{array}$ \\
\hline A & $\begin{array}{l}\text { Cedar Swamp Creek at Glen } \\
\text { Cove. } \\
\text { Roslyn Brook at Roslyn }\end{array}$ & $\begin{array}{l}\text { Water-stage recorder } \\
\text { Average 1938-55. } \\
\text { Periodic measurements }\end{array}$ & $\begin{array}{l}\text { 7. } 40 \\
\text { 2. } 56\end{array}$ \\
\hline $\mathbf{C}$ & Whitney Lake outlet at Man- & $\begin{array}{l}\text { Average 1953-57. } \\
\text { Periodic measurements } \\
\text { Average } 1953-57\end{array}$ & 2. 90 \\
\hline D & Leeds Pond inlet at Plandome _. - & Discharge measurement & 1. 03 \\
\hline $\mathrm{E}$ & Leeds Pond outlet at Plandome_ & $\begin{array}{l}\text { Discharge measurement } \\
\text { December } 28,1956 .\end{array}$ & 2. 46 \\
\hline $\mathbf{F}$ & $\begin{array}{l}\text { Flower Hill drain, at site of vil- } \\
\text { lage of Plandome Public Water } \\
\text { Supply. }\end{array}$ & $\begin{array}{l}\text { Discharge measurement } \\
\text { December 28, } 1956 .\end{array}$ & .51 \\
\hline G & $\begin{array}{l}\text { Plandome - Port Washington } \\
\text { drain at site of Port Washing- } \\
\text { ton incinerator. }\end{array}$ & $\begin{array}{l}\text { Discharge measurement } \\
\text { December 28, } 1956 .\end{array}$ & .31 \\
\hline $\mathbf{H}$ & $\begin{array}{l}\text { Plandome - Port Washington } \\
\text { drain } 300 \mathrm{ft} \text {. west of culvert } \\
\text { under railroad embankment } \\
\text { at Plandome Country Club. }\end{array}$ & $\begin{array}{l}\text { Discharge measurement } \\
\text { December } 28,1956 .\end{array}$ & .69 \\
\hline $\mathbf{I}$ & $\begin{array}{l}\text { Baxters Brook, at Baxter Estates, } \\
\text { Port Washington. }\end{array}$ & Discharge measurement. . & .55 \\
\hline $\mathbf{J}$ & $\begin{array}{l}\text { Mitchell's Creek, near Kings } \\
\text { Point. }\end{array}$ & $\begin{array}{l}\text { Discharge measurement } \\
\text { January } 15,1953 .\end{array}$ & .86 \\
\hline $\mathbf{K}$ & $\begin{array}{l}\text { Unnamed creek, flowing north } \\
\text { near Kings Point. }\end{array}$ & $\begin{array}{l}\text { Discharge measurement } \\
\text { March } 12,1957 .\end{array}$ & .82 \\
\hline $\mathbf{L}$ & $\begin{array}{l}\text { Old Mill Brook at site of sewage- } \\
\text { treatment plant, Great Neck. }\end{array}$ & $\begin{array}{l}\text { Discharge measurement } \\
\text { January } 15,1953 .\end{array}$ & .39 \\
\hline $\mathbf{M}$ & $\begin{array}{l}\text { Cutter Mill drains, } 40 \text { ft up- } \\
\text { stream from culvert under } \\
\text { railroad embankment, Great } \\
\text { Neck. }\end{array}$ & $\begin{array}{l}\text { Discharge measurement } \\
\text { March } 12,1957\end{array}$ & 1. 39 \\
\hline
\end{tabular}

(See "References cited.") Comparatively uniform salinity prevails throughout the year at the Willets Point tide station, where the mean (1932-52) monthly salinity ranges only from 24,100 to $25,900 \mathrm{ppm}$. At the same station, the mean (1932-50) surface-water temperature ranges from $33.7^{\circ} \mathrm{F}$ in February to $71.7^{\circ} \mathrm{F}$ in August. For the same period of record, a mean annual temperature of $52.5^{\circ} \mathrm{F}$ is reported (U.S. Dept. Commerce). Considering a time lag of about 1 month, water temperarure agrees closely with observed mean monthly air temperature.

A complete chemical analysis of water from Long Island Sound, collected off Prospect Point, is given in table 9. The chloride concentration of $15,700 \mathrm{ppm}$ is slightly less than that of a sample from the Atlantic Ocean (table 9). Chloride content from several water samples taken in Hempstead Harbor and Manhasset Bay ranged from 12,300 to $14,400 \mathrm{ppm}$ (table 10 ). These values indiate fairly constant salinity in the bays and harbors and only minor fletuations due to tidal stage. 
TABLE 9.-Chemical analyses of water from Long Island Sound and Atlantic Ocean [Analyses by U.S. Geol. Survey; chemical constituents in parts per million]

\begin{tabular}{|c|c|c|}
\hline Constituent & $\begin{array}{l}\text { Lnng Island } \\
\text { Sound } 1\end{array}$ & $\begin{array}{l}\text { Atlantic } \\
\text { Ocean 2 }\end{array}$ \\
\hline 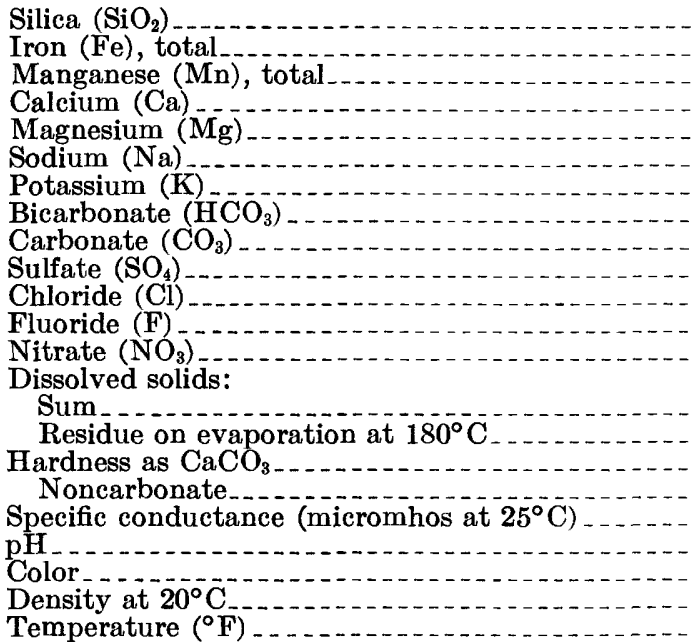 & $\begin{array}{c}3.5 \\
.09 \\
346 \\
1,02 \\
8,730 \\
327 \\
113 \\
0 \\
2,120 \\
15,700 \\
1.1 \\
1.0 \\
28,300 \\
29,600 \\
5,190 \\
5,090 \\
41,600 \\
7.1 \\
5 \\
1.017 \\
60\end{array}$ & \begin{tabular}{c}
1.2 \\
1.3 \\
$351^{.00}$ \\
1,190 \\
9,520 \\
373 \\
129 \\
0 \\
2,290 \\
17,200 \\
.0 \\
1.1 \\
31,000 \\
\hdashline, 770 \\
5,660 \\
47,100 \\
7.6 \\
3 \\
1.019 \\
43
\end{tabular} \\
\hline
\end{tabular}

1 Collected off jetty at Prospect Point, Sands Point, N.Y., Oct. 22, 1957, near high tide.

$\&$ Collected off jetty at Atlantic Beach, N.Y., Apr. 18, 1956, near high tide.

TABLE 10.-Chloride analyses of surface water in northwestern Nassau County, N.Y.

[Analyses by U.S. Geological Survey]

\begin{tabular}{|c|c|c|c|c|}
\hline $\begin{array}{l}\text { Sampling } \\
\text { point } \\
\text { (fig. 14) }\end{array}$ & Location & Date & $\begin{array}{l}\text { Chloride } \\
\text { (ppm) }\end{array}$ & Remarks \\
\hline $\begin{array}{r}1 \\
2 \\
3 \\
4 \\
5 \\
6 \\
7 \\
8 \\
9 \\
10 \\
11 \\
12 \\
13 \\
14 \\
15\end{array}$ & 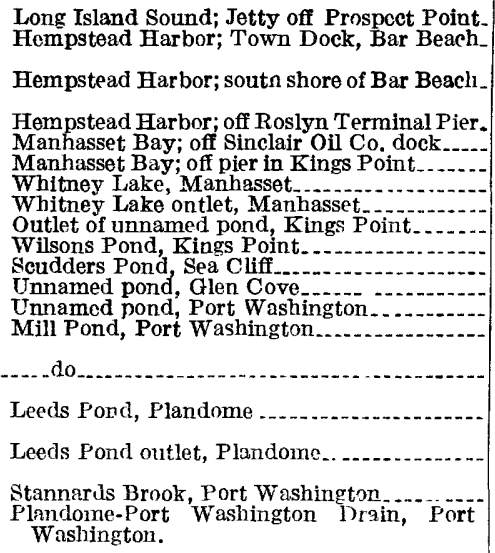 & $\begin{array}{l}\text { Oct. } 22,1957 \\
\text { Mar. 15, 1957 } \\
\text { Mar. 11, 1957 } \\
\text { Mar. 15, 1957 } \\
\text { Mar. 11,1957 } \\
\text { Jan. 11, 1957 } \\
\text { Oct. } 18,1957 \\
\text { Mar. 12,1957 } \\
\text { Oct. 18, 1957 } \\
\text { Mar. 12,1957 } \\
- \\
\text { Oct. }\end{array}$ & $\begin{array}{r}15,700 \\
14,400 \\
12,700 \\
14,150 \\
12,850 \\
12,300 \\
14,100 \\
13,250 \\
10 \\
10 \\
14 \\
12,250 \\
980 \\
12 \\
20 \\
2,800 \\
1,800 \\
4,200 \\
1,900 \\
1,500 \\
3,000 \\
6,500 \\
4,300 \\
22 \\
17\end{array}$ & $\begin{array}{l}\text { Near south end. } \\
\text { Near east end. } \\
\text { Near outlet. } \\
\text { Near east end. } \\
\text { Do. } \\
\text { Near west end. } \\
\text { Do. } \\
\text { Near south ond. } \\
\text { Do. } \\
\text { Ortlet culvert. } \\
\text { Below spillway. } \\
\text { Near well N2635. } \\
\text { Near well N2269. }\end{array}$ \\
\hline
\end{tabular}


The water of ponds and streams in the project area normally contains less than $30 \mathrm{ppm}$ chloride (See table 10). However, some ponds in shore areas afford ingress to particularly high tides and thus may be brackish at times. Chloride determinations of water from the larger tidal ponds are included in table 10 . The location of surfacewater sampling points is shown in figure 14 .

The water temperature of streams fluctuates seasonalls with air temperature, but within narrower extremes. A moderating influence is exercised by the temperature of the ground-water inflow, which generally sustains streamflow. Temperature in upstream reaches of a stream may be modified to a greater extent by prevailing groundwater temperature than that in downstream reaches, where air temperature and atmospheric conditions may become the dominant modifying factors. Thus, water temperatures vary from stream to stream and also along different reaches of the same stream. Monthly water-temperature measurements of some streams in erstern and southern Nassau County are given by R. M. Sawyer (1958). The data show general agreement of water temperature with monthly mean air temperature.

\section{UTILIZATION OF SURFACE WATER}

Fresh surface-water sources are not utilized in no"thwestern Nassau County for industrial or public supplies. Salt water pumped from Hempstead Harbor and Manhasset Bay is used in several sand and gravel pits for washing and size-sorting operations and in settling ponds. Large quantities of salt water also are used for cooling purposes at a power-generating plant in Glenwood Landing.

\section{SUMMARY AND CONCLUSIONS}

In general, ground-water supplies in sufficient quantity and of excellent quality can be obtained from the three aquifers underlying northwestern Nassau and northeastern Queens Counties. Groundwater withdrawals for public supply have increased with population growth and expanded use from about $10 \mathrm{mgd}$ in 1940 to $30 \mathrm{mgd}$ in 1957. In addition, about $10 \mathrm{mgd}$ are pumped for various industrial, institutional and private uses. Much of the water pumped for industrial purposes is returned to the ground by diffusior wells and recharge basins. However, an increasing amount of water is lost from the ground-water reservoir owing to the expanding network of sewer systems discharging directly to the sea, whereas formerly this water was artificially returned to the ground through individual cesspools or municipal leaching fields.

$690-186-63-6$ 
The ground-water resources are approaching full development in terms of total available supply in the Great Neck and Manhesset Neck areas, if such development has not been reached alreac'y (1959). The chief factor limiting further development is the geometry of the aquifers and the reduced thickness of permeable saturated sediments. In the northern parts of both peninsulas, the ground-water reservoir is less than 400 feet thick, and locally up to 75 percent of the strata in the reservoir consists of impermeable silts and clays of th 9 Raritan formation or the Gardiners clay. In these areas, substantial quantities of water can be obtained only from the deep-confined aquifer (Jameco gravel or Lloyd sand member of the Raritan formation).

The eastern and southeastern part of the project area, where a maximum of natural recharge occurs, offers the largest potential for future increased withdrawals. In an area circumscribed by the 60 -foot contour of the water table (pl. 9), including the ground-water divide, no significant changes other than fluctuations attributed to precipitation patterns or to temporary local pumping have occurred since 1903. However, in the southwestern part of the project area, water levels have declined as much as 15 feet since 1903 is a result of heavy withdrawals in central Queens. A small increass of withdrawals in the eastern and northeastern part of the project area probably would not alter the position of the water table appreciably. Moreover, within limits not yet prescribed, additional withdrawals would increase gradients and induce greater ground-water flow from adjacent, virtually untapped sources to the east of the project area, without detrimental effects to the ground-water reservoir. Much of the ground water in the principal aquifer reaches Manhasset and Great Necks by underflow from the south, as shown in plates 8 and 12 . Some increase in withdrawals from the principal aquifer in the southern part of the peninsulas also would steepen the northward gradients from the main ground-water reservoir and intercept some of the ground water discharging laterally into the bays. Such withdrawals from the principal aquifer would have to be regulated to maintair sufficient pressure heads in the aquifer to prevent sea-water encroachment and to provide recharge to the deep confined aquifer.

In some places along the north shore of the project are?, effluent streams discharge considerable quantities of ground wate" to Long. Island Sound and its bays. The utilization of stream runoff, by direct diversion or by induced infiltration through shallow wells in such valleys as that of Cedar Swamp Creek in Glen Cove or Roslyn Brook (fig. 14), may provide a future source of water for lccal industrial needs. This means of water utilization would be s'ited particularly to areas where only a small part of the ground-wate" reservoir 
can be developed and where a concentration of wells would cause excessive lowering of water levels.

A particular problem within the project area is the withdrawal of water from wells screened in the deep confined aquifer in near-shore zones. Sea-water encroachment caused by excessive pumping has occurred already at one pumping installation (N35, N4859, table 15) in Port Washington. In other zones, salt-water encroacl ment may be impending, as indicated by abnormally high chloride consentrations in some wells, as for example wells N906, N1926, and N2424, tables 14 and 15. Therefore, the observation-well program, maintained by the Nassau County Department of Public Works and the New York State Water Resources Commission, in cooperation with the U.S. Geological Survey, should be continued and revised from time to time to conform to changing withdrawal patterns in the various aquifers. In addition to a program of regular water-level measurem ents, there is need for a chloride-monitoring program for wells along: the north shore, particularly for those screened in the deep confin'd aquifer. Furthernore, periodic sampling of water from wells in the f ${ }^{n}$ oject area for temperature determination and chemical analysis would be desirable to detect changes in the quality of ground water.

Although only isolated instances of contamination othor than by salt water have been recognized in wells tapping water at shallow and intermediate depths, a considerable increase in population density since 1950 (table 1) and industrial expansion in the project area may affect adversely the quality of future ground-water supplie. Among such sources of contamination are: (1) synthetic detergents and organic wastes which move into the ground from cesspools, septic tanks, and leaching fields; (2) industrial wastes which may enter the ground from disposal dumps or leaching basins; and (3) soluble infiltrates from refuse dumps. Increased use of ground water for air conditioning and industrial cooling and recharge through diffusion wells of the spent water will tend to raise the temperature of the ground water and thereby reduce its utility for cooling.

Major man-made changes in the physical character of the peninsulas have occurred by the removal of large quantities of sand and gravel for construction. This physical change has diminished the natural storage capacity of the ground-water reservoir ard also has reduced over a considerable area (about 900 acres on Manhasset Neck) the natural fresh-water head in the shallow unconfined aquifer. The net result of these changes in the natural environment is to facilitate sea-water encroachment in areas artificially reduced to near sea level by excavation. Furthermore, aquifers mry be contaminated by salt water indirectly as the result of the artificial removal of confining impermeable strata in nearshore or offshore areas. 
As shown in figure 6, ground water in the area of the north-shore bays is confined by clay in Recent and Pleistocene deporits. The removal of these confining strata by shoreline excavations or by offshore dredging accelerates upward leakage and discharge of fresh ground water, with a resultant loss in head some distance inland. This pressure loss would tend to reduce existing fresh-water barriers between the bays and pumping centers and also to cause a landward and upward shift in the position of fresh-salt-water interfaces.

As annual ground-water withdrawals in the project area approach the total available supply, the need for more detailed eveluation of all factors that might affect the selection of future well sites and rates of ground-water withdrawal will be increased. Such factors would include: (1) closer definition of the geohydrological environment by test drilling; (2) detailed examination of flow patterns in the groundwater reservoir by means of flow-net analysis; (3) close temperature and quality monitoring, particularly for chloride concentrations in critical areas; and (4) detailed quantitative evaluations of critical sectors of the project area. In some sectors of the project area, only one aquifer is fully developed, and additional supplias may be obtained from other aquifers at greater or shallower depth within the reservoir. In other areas, however, increased supplies may become available only by the relocation of existing (1959) Water District franchise boundaries.

\section{REFERENCES CITED}

Brice, H. D., Whitaker, C. L., and Sawyer, R. M., 1959, A progress report on the disposal of storm water at an experimental seepage basin nэar Mineola, New York: U.S. Geol. Survey open-file report, $34 \mathrm{p}$.

de Laguna, Wallace, 1948, Geologic correlation of logs of wells in Kings County, New York: New York State Water Power and Control Comm. F ’ll. GW-17, p. 16.

de Laguna, Wallace, and Brashers, M. L., Jr., 1948, The configuration of the rock floor in western Long Island, New York: New York State Nater Power and Control Comm. Bull. GW-13, 32 p.

Fleming, W. L. S., 1935, Glacial geology of central Long Island: Am. Jour. Sci., 5th ser., v. 30 , no. 177 , p. $216-238$.

Flint, R. F., 1957, Glacial and Pleistocene geology: New York, John Wiley \& Sons, $359 \mathrm{p}$.

Flint, R. F., and others, 1959, Glacial map of the United States east of the Rocky Mountains: Geol. Soc. America, spec. map (in color).

Fuller, M. L., 1914, The geology of Long Island, New York: U.S. Geol. Survey Prof. Paper 82.

Hyyppä, Esa, 1955, On the Pleistocene geology of southeastern New England: Comm. Geol. Finlande Bull. no. 167, p. 157-225.

Isbister, John, 1959, Ground-water levels and related hydrologic data from selected observation wells in Nassau County, Long Island, New York: New York State Water Power and Control Comm. Bull. GW-41. 
Leggette, R. M., and others, 1938a, Record of wells in Nassau County, New York: New York State Water Power and Control Comm. Bull. GW-5, $140 \mathrm{p}$.

- 1938b, Record of wells in Queens County, New York: New York State Water Power and Control Comm. Bull. GW-6, 240 p.

Lounsbury, C., and others, 1928, Soil survey of Suffolk and Nassau Counties, New York: U.S. Dept. Agriculture, ser. 1928, no. 28, 46 p.

MacClintock, Paul and Richards, H. G., 1936, Correlation of late Pleistocene marine and glacial deposits of New Jersey and New York: Geol. Soc. America Bull. 47, p. 289-338.

Oliver, J. E., and Drake, Chas. L., 1951, Geophysical investigations in the emerged and submerged Atlantic coastal plain, pt. 6, The Long Island area: Geol. Soc. America Bull., v. 62, p. 1287-1296.

Perlmutter, N. M., and Crandell, H. C., 1959, Geology and ground-water supplies of the south-shore beaches of Long Island, New York: New York Acad. Sci. Annals, v. 80, art. 4, p. 1060-1076.

Perlmutter, N. M., Geraghty, J. J., and Upson, J. E., 1959, The relation between fresh and salty ground water in southern Nassau and southeastern Queens Counties, Long Island, New York: Econ. Geol., v. 54, p. 416-435.

Roberts, C. M., and Brashears, M. L., Jr., 1946, Record of wells in Nassau County, New York, Supp. 1: New York State Water Power and Control Comm. Bull. GW-10, 191 p.

Roberts, C. M., and Jaster, M. C., 1947, Record of wells in Queens County, New York, Supp. 1: New York State Water Power and Control Comm. Bull. GW-11, 123 p.

Sawyer, R. M., 1958, Progress report on streamflow investigations in Nassau County, Long Island, New York: U.S. Geol. Survey open-file report, 226 p.

Suter, Russell, de Laguna, Wallace, and Perlmutter, N. M., 1949, Mapping of geologic formations and aquifers of Long Island, New York: New York State Water Power and Control Comm. Bull. GW-18, 212 p.

Theis, C. V., and others, 1954, Estimating transmissibility from specific capacity: U.S. Geol. Survey open-file report, 11 p.

U.S. Dept. Commerce, Coast and Geod. Survey, 1951, Surface water temperatures at tide stations, Atlantic Coast, North and South America-Spsc. Pub. no. 278: Washington, U.S. Govt. Printing Office, 57 p.

1953, Density of sea water at tide stations, Atlantic Coast. North and South America-Spec. Pub. no. 279: Washington, U.S. Govt. Printing Office, $62 \mathrm{p}$.

U.S. Public Health Service, 1946, Drinking water standards: Reprint 2697, Public Health Reports, v. 61, no. 11, p. 371-384

Veatch, A. C., and others, 1906, Underground water resources of Long Island New York: U.S. Geol. Survey Prof. Paper 44.

Weiss, Lawrence, 1954, Foraminifera and origin of the Gardiners clay (Pleistocene), eastern Long Island, New York: U.S. Geol. Survey Prof. Paper 254-G, p. 143-163.

Wenzel, L. K., and Fishel, V. C., 1942, Methods for determining permeability of water-bearing materials: U.S. Geol. Survey Water-Supply Paper 887, $192 \mathrm{p}$. 



\section{BASIC DATA}




\section{TABLE 11.-Records of selected wells in rorthwestern}

[For location of wells, see pl. 1]

Map coordinates: First number and letter indicate grid square on pl. 1. Remainder is distance in miles first north and then west from southeast corner of grid square.

Owner: W.D., Water District

Jam. W.S.C., Jamaica Water Supply Company

Cit. W.S.C., Citizens' Water Supply Company of Newtown

N.Y.C.D.W.S.G.\& E., New York City Department of Water Supply, Gas and Electrict ty

U.S.G.S., United States Geological Survey.

Altitude of reference point: Reference point is not more than $3 \mathrm{ft}$ above or below land surface unless otherwise indicated in "Remarks" colmmn. Figures given in tenths of feet are based on spirit, levels; others are interpolated from topographic maps. Altitudes are referred to mean sea level.

Water-yielding unit: uP, upper Pleistocene deposits; P, Pleistocene deposits, undifferentia+ed; J, Jameco gravel; M, Magothy(?) formation, L, Lloyd sand member of Raritan formation.

Water level: Water levels given in tenths of feet are measured; others are reported. A plus (+) sign indicates water level is above reference point.

\begin{tabular}{|c|c|c|c|c|c|c|c|c|}
\hline Well & $\underset{\text { coordinates }}{\text { Map }}$ & Owner & Location & 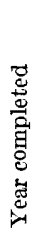 & 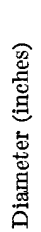 & 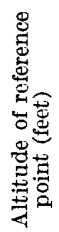 & 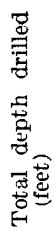 & $\begin{array}{c}\text { Screen } \\
\text { setting } \\
\text { below land } \\
\text { surface } \\
\text { (feet) }\end{array}$ \\
\hline
\end{tabular}

NASSAU

\begin{tabular}{|c|c|c|c|c|c|c|c|c|}
\hline N15 & $1 \mathrm{C}, 1.0 \mathrm{~N}$ & Jain. W. S. C & New Hyde Park. & 1928 & $36-26$ & 116.8 & 107 & $73-102$ \\
\hline 263 & $2 \mathrm{~B}, 0.6 \mathrm{~N}$ & W. K. Vanderbilt, & Lake Success...- & $-\ldots$ & $8-413$ & 171 & 755 & $700-750$ \\
\hline 1328 & $\begin{array}{c}2 \mathrm{C}, 2.6 \mathrm{~N} \\
0.9 \mathrm{~W}\end{array}$ & $\begin{array}{l}\text { Jr. } \\
\text { Manhasset-Lake- } \\
\text { ville W. D. }\end{array}$ & North Hills.....- & 1941 & $50-12$ & 175.8 & 770 & $652-742$ \\
\hline 3458 & $\begin{array}{l}3 \mathrm{D}, 1.8 \mathrm{~N}, \\
1.7 \mathrm{~W}\end{array}$ & $\begin{array}{l}\text { Wm.J. McCor- } \\
\text { mack. }\end{array}$ & Port Washington_- & 1950 & $4-2$ & 51.2 & 50 & $36-50 \ldots$ \\
\hline 4859 & $\begin{array}{l}4 \mathrm{C}, 0.2 \mathrm{~N} \\
1.5 \mathrm{~W}\end{array}$ & $\begin{array}{l}\text { Port Washington } \\
\text { W. D. }\end{array}$ & .....do do & 1954 & 12 & 31.3 & 389 & $355-385$ \\
\hline 5209 & $3 \mathrm{C}, 2.5 \mathrm{~N}$ & _... do do & - & 1955 & $20-12$ & 197 & 298 & $259-299$ \\
\hline 5210 & $3 \mathrm{C}, 2.5 \mathrm{~N}$ & -.... do_... & -... do do....... & 1955 & 6 & 201.0 & 302 & $292-302$ \\
\hline 5228 & $\begin{array}{l}0.0 \mathrm{~W} \dot{\mathrm{N}}, 1.1 \mathrm{~N}, \\
2.1 \mathrm{~W} .\end{array}$ & - & Flower Hill... & 1955 & 6 & 160.2 & 334 & $324-334$ \\
\hline 5251 & $3 \mathrm{C}, 1.3 \mathrm{~N}$ & Milton Wuishpard. & Plandorne & 1955 & 6 & 90 & 108 & $98-108$ \\
\hline 5296 & $\begin{array}{c}2 \mathrm{~B}, 2.5 \mathrm{~N} \\
2.1 \mathrm{~W}\end{array}$ & $\begin{array}{l}\text { Vil. of Great Neck } \\
\text { Estates. }\end{array}$ & $\begin{array}{l}\text { Great Neck Es- } \\
\text { tates. }\end{array}$ & 1955 & 6 & 20 & 146 & $39-50 \ldots$ \\
\hline 5357 & $\begin{array}{c}3 \mathrm{~B}, 2.4 \mathrm{~N} \\
1.6 \mathrm{~W}\end{array}$ & Dr. David Bellin.- & Kings Point & 1955 & 4 & 18 & 283 & \\
\hline 5450 & $\begin{array}{c}3 \mathrm{D}, 2.1 \mathrm{~N} \\
0.6 \mathrm{~W}\end{array}$ & $\begin{array}{l}\text { Engineers' Coun- } \\
\text { try Club. }\end{array}$ & $\begin{array}{l}\text { Glenwood Land- } \\
\text { ing. }\end{array}$ & 1955 & 12 & 56 & 80 & $58-80 \ldots$ \\
\hline 5528 & $\begin{array}{c}3 \mathrm{C}, 0.1 \mathrm{~N}, \\
0.1 \mathrm{~W}\end{array}$ & $\begin{array}{l}\text { Manhasset-Lake- } \\
\text { ville W. D. }\end{array}$ & North Hills..... & 1955 & $20-12$ & 253.7 & 515 & $430-490$ \\
\hline 5530 & $\begin{array}{c}3 \mathrm{C}, 2.5 \mathrm{~N} \\
1.5 \mathrm{~W}\end{array}$ & $\begin{array}{l}\text { Port Washington } \\
\text { W. D. }\end{array}$ & Port Washington & 1955 & 6 & 63.9 & 436 & 372-382. \\
\hline $5535 \mathrm{~T}$ & $\begin{array}{c}2 \mathrm{C}, 1.5 \mathrm{~N} \\
1.4 \mathrm{~W}\end{array}$ & Deepdale, Inc..... & North Hills... . & 1955 & 6 & 250 & 435 & \\
\hline 5535 & $2 \mathrm{C}, 1.5 \mathrm{~N}$ & -.... do & - & 1956 & $16-12$ & 242.2 & 370 & $330-370$ \\
\hline $5576 \mathrm{D}$ & $\begin{array}{c}2 \mathrm{~B}, 2.8 \mathrm{~N} \\
1.1 \mathrm{~W}\end{array}$ & Squire Theater...- & Great Neck..... & 1955 & 4 & 94.4 & 249 & $\begin{array}{l}35-45,76- \\
102,169- \\
174,195- \\
205\end{array}$ \\
\hline 5603 & $\begin{array}{l}2 \mathrm{C}, 0.5 \mathrm{~N} \\
0.3 \mathrm{~W}\end{array}$ & $\begin{array}{l}\text { Garden City Park } \\
\text { W. D. }\end{array}$ & $\begin{array}{l}\text { Garden City } \\
\text { Park. }\end{array}$ & 1955 & $18-12$ & 112.9 & 452 & $365-415$ \\
\hline $5621 \mathrm{~T}$ & $\begin{array}{l}3 \mathrm{C}, 1.6 \mathrm{~N}, \\
1.2 \mathrm{~W}\end{array}$ & $\begin{array}{l}\text { Port Washington } \\
\text { W. D. }\end{array}$ & Port Washington & 1955 & 6 & 95 & 280 & \\
\hline 5679 & $4 \mathrm{D}, 0.3 \mathrm{~N}$ & $\begin{array}{l}\text { Colonial Sand \& } \\
\text { Stone Co. }\end{array}$ & -................. & $1920 ?$ & 5 & 13.5 & 401」= & $\begin{array}{l}\text { Bottom at } \\
401 \pm .\end{array}$ \\
\hline 5680 & $\begin{array}{l}3 \mathrm{D}, 1.7 \mathrm{~N} \\
1.7 \mathrm{~W}\end{array}$ & $\begin{array}{l}\text { Wm.J. McCor- } \\
\text { mack. }\end{array}$ & .... do... & 1955 & $2^{1} \cdot 2$ & 36.8 & 106 & \\
\hline
\end{tabular}


Nassau and northeastern Queens Counties, N.Y.

Pump capacity: Given in gallons per minute (gpm).

Speciflc capacity: Gallons per minute per foot of drawdown.

Use: PS, Public supply; Dom, domestic or institutional; Ind, industrial; Irr, irrigation: 0 , observation; $T$, test hole; A, abandnned.

Remarks: (1) For well log, sce Bull. GW-5 "Record of wells in Nassal1 County, N.Y." Now York State Water Power and Control Commission, 1438. (2) For well log, see Bull. GW-10 "Record of wells in Nassau County, N.Y., Supplement 1," New York State Water Power and Control Commission, 1946. (3) Well number in U..S. Geol. Survey Professional Paper 44, "Underground water resources of Long Island," 1906, by A. C. Veatch. (4) For log, see table 12. (5) For chemical analyses, see table 14. (6) For additional chloride analyses, see table 15. (7) For additional water-level data, see table 13. (8) For well log, see Bull. GW-6 "Record of wells in Queens Coun ty, N.Y." New York State Water Power and Control Commission, 1938. (9) For well log, see Bull. GW-11 "Record of wells in Queens County, N.Y., Supplement 1," New York State Water Power and Control Commission, 1947.

\begin{tabular}{|c|c|c|c|c|c|c|c|c|}
\hline \multirow{2}{*}{ 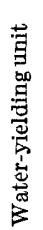 } & \multirow{2}{*}{ 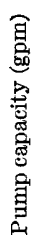 } & \multirow[b]{2}{*}{ 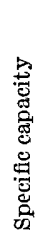 } & \multirow[b]{2}{*}{$\begin{array}{l}\Phi \\
\stackrel{\Phi}{\sigma}\end{array}$} & \multicolumn{2}{|c|}{ Water level } & \multicolumn{2}{|c|}{ Chloride } & \multirow[b]{2}{*}{ Remarks } \\
\hline & & & & 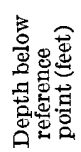 & Date & 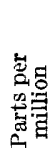 & Date & \\
\hline
\end{tabular}

\section{COUNTY}

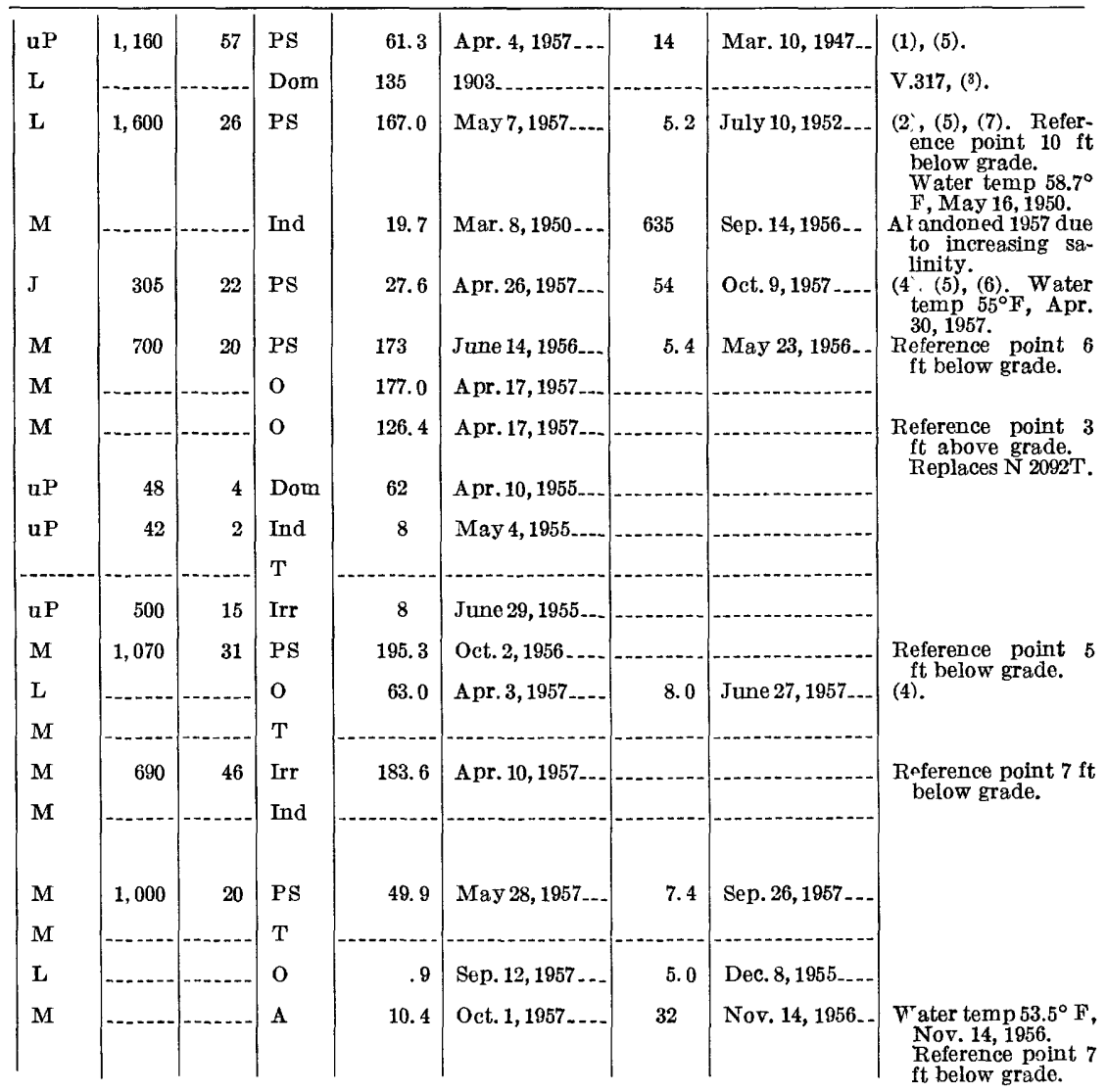


TABLE 11.-Records of selected wells in northwestern

\begin{tabular}{|c|c|c|c|c|c|c|c|c|}
\hline Well & $\underset{\text { coordinates }}{\text { Map }}$ & Owner & Location & 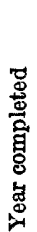 & 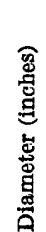 & 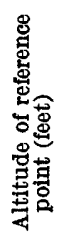 & 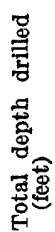 & $\begin{array}{c}\text { Screen } \\
\text { setting } \\
\text { below land } \\
\text { surface } \\
\text { (feet) }\end{array}$ \\
\hline
\end{tabular}

NASSAU

\begin{tabular}{|c|c|c|c|c|c|c|c|c|}
\hline N5686 & & City of Glen Cove. & Glen Cove.......... & 1956 & 6 & 12.6 & 92 & $84-92 \ldots$ \\
\hline 5710 & $2 \mathrm{C}, 1.1 \mathrm{~N}$, & $\begin{array}{l}\text { Manhasset-Lake- } \\
\text { ville W. D. }\end{array}$ & Lake Success.... & 1956 & $20-12$ & 167.5 & 396 & $325-385$ \\
\hline 5743 & $3 \mathrm{~A}, 1.8 \mathrm{~N}$, & Robert Zwerling. - & Kings Point....- & 1956 & 6 & 65 & 52 & 48-53.. \\
\hline 5792 & $\begin{array}{c}4 \mathrm{D}, 0.4 \mathrm{~N} \\
0.1 \mathrm{~W}\end{array}$ & $\begin{array}{l}\text { Sea Cliff Water } \\
\text { Co. }\end{array}$ & Sea Cliff......... & 1956 & 20-12 & 145.5 & 361 & $255-295$. \\
\hline 5852 & $\begin{array}{c}3 \mathrm{D}, 0.7 \mathrm{~N}, \\
0.3 \mathrm{~W} .\end{array}$ & Roslyn W.D...... & East Hills........ & 1956 & $18-12$ & 240 & 517 & $432-482$ \\
\hline 5876 & $\begin{array}{c}3 \mathrm{C}, 1.6 \mathrm{~N}, \\
1.2 \mathrm{~W}\end{array}$ & $\begin{array}{l}\text { Port Washington } \\
\text { W.D }\end{array}$ & Port Washing- & 1956 & 20-12 & 86 & 295 & $168-238$ \\
\hline 5883 & $\begin{array}{l}3 \mathrm{D}, 1.0 \mathrm{~N}, \\
0.6 \mathrm{~W}\end{array}$ & $\begin{array}{l}\text { Helena Ruben- } \\
\text { stein. }\end{array}$ & East Hills........ & 1956 & 4 & 210.1 & 226 & $207-215$ \\
\hline 5884T & $\begin{array}{l}3 \mathrm{~B}, 0.6 \mathrm{~N} \\
0.5 \mathrm{~W}\end{array}$ & Cit. W.S.C. & Great Neck..... & 1956 & 6 & 66 & 228 & \\
\hline 5884 & $\begin{array}{c}3 \mathrm{~B}, 0.6 \mathrm{~N} \\
0.5 \mathrm{~W}\end{array}$ & .....do_........... & ..... do & 1956 & 18 & 63.6 & 166 & $92-163$ \\
\hline 5895 & $3 \mathrm{~B}, 1.5 \mathrm{~N}$ & George Goldberg-- & Kings Point...... & 1956 & 6 & 60 & 150 & $126-138$ \\
\hline 5903 & $3 \mathrm{~B}, 1.5 \mathrm{~N}$, & David Gimpel.... & .... do & 1956 & 6 & 40 & 83 & $77-83$ \\
\hline 5918 & $\begin{array}{l}3 \mathrm{C}, 1.6 \mathrm{~N}, \\
1.2 \mathrm{~W}\end{array}$ & $\begin{array}{l}\text { Port Washington } \\
\text { W.D. }\end{array}$ & $\begin{array}{l}\text { Port Washing. } \\
\text { ton. }\end{array}$ & 1956 & 6 & 96. 6 & 188 & $178-188$ \\
\hline 5947 & $2 \mathrm{D}, 2.1 \mathrm{~N}$ & Albertson W.D & Albertson........ & 1956 & $20-12$ & 122.3 & 504 & $295-365$ \\
\hline 6012 & $3 \mathrm{~A}, 2.4 \mathrm{~N}$ & L. Schoenfeld. - & Kings Point...... & 1956 & 4 & 45 & 130 & $119-130$ \\
\hline 6023 & $\begin{array}{l}3 \mathrm{C}, 2.1 \mathrm{~N} \\
2.0 \mathrm{~W}\end{array}$ & U.S.G.S... & Plandome........ & 1956 & $11 / 4$ & 7.6 & 5 & $3-5 \ldots$ \\
\hline 6024 & $\begin{array}{l}4 \mathrm{D}, 0.3 \mathrm{~N}, \\
2.1 \mathrm{~W}\end{array}$ & $\ldots d o_{-}$ & $\begin{array}{l}\text { Port Washing- } \\
\text { ton. }\end{array}$ & 1956 & $11 / 4$ & 15.6 & 22 & $20-22$. \\
\hline 6025 & $3 \mathrm{D}, 1.8 \mathrm{~N}$, & ......do. & & 1956 & $11 / 4$ & 14.0 & 12 & $10-12$ \\
\hline 6026 & $\begin{array}{l}3 \mathrm{D}, 1.7 \mathrm{~N}, \\
1.7 \mathrm{~W} .\end{array}$ & .............. & -...do_.... & 1956 & $11 / 4$ & 39.2 & 17 & $15-17-$ \\
\hline 6027 & $\begin{array}{l}3 \mathrm{D}, 0.7 \mathrm{~N} \text {, } \\
1.5 \mathrm{~W} .\end{array}$ & -........... & Roslyn & 1956 & $11 / 4$ & 24.5 & 17 & $15-17$ \\
\hline 6028 & $3 \mathrm{D}, 0.7 \mathrm{~N}$ & ........ do & _..._do.......... & 1956 & $11 / 4$ & 21.7 & 7 & $5-7-\ldots$ \\
\hline 6029 & $\begin{array}{l}3 \mathrm{D}, 0.7 \mathrm{~N} \\
1.5 \mathrm{~W}\end{array}$ & -............. & _....do_....... & 1956 & $11 / 4$ & 16.3 & 7 & $5-7 \ldots$ \\
\hline 6030 & $\begin{array}{l}3 \mathrm{D}, 2.5 \mathrm{~N}, \\
1.7 \mathrm{~W} .\end{array}$ & ............... & $\begin{array}{l}\text { Port Washing- } \\
\text { ton. }\end{array}$ & 1956 & $11 / 4$ & 8.3 & 10 & $8-10 \ldots$ \\
\hline 6031 & $\begin{array}{l}4 \mathrm{~B}, 1.3 \mathrm{~N} \\
0.5 \mathrm{~W}\end{array}$ & ...... do...... & Sands Point...... & 1956 & $21 / 2$ & 30.8 & 40 & $38-40$ \\
\hline 6033 & $\begin{array}{l}3 \mathrm{C}, 2.2 \mathrm{~N} \\
1.0 \mathrm{~W}\end{array}$ & - do do & $\begin{array}{l}\text { Port Washing- } \\
\text { ton. }\end{array}$ & 1956 & $2^{1 / 2}$ & 118.0 & 18 & $16-18$ \\
\hline 6034 & $\begin{array}{c}3 \mathrm{C}, 0.3 \mathrm{~N} \\
0.3 \mathrm{~W}\end{array}$ & $\begin{array}{l}\text { Fifth Ave. Shop- } \\
\text { ping Center. }\end{array}$ & Manhasset...... & 1956 & $16-12$ & 204.3 & 313 & $227-297$ \\
\hline 6035 & $\begin{array}{c}3 \mathrm{C}, 0.3 \mathrm{~N} \\
0.2 \mathrm{~W}\end{array}$ & -.... do & .....do... & 1956 & $16-12$ & 189.7 & 293 & $\begin{array}{c}192-209, \\
229-273 \\
283-29\end{array}$ \\
\hline 6083 & $\begin{array}{l}3 \mathrm{~B}, 0.4 \mathrm{~N} \\
2.0 \mathrm{~W}\end{array}$ & $\begin{array}{l}\text { Great Neck Sew- } \\
\text { age District. }\end{array}$ & Great Neck & 1956 & 4 & 10 & 110 & $102-106 \ldots$ \\
\hline 6087 & $\begin{array}{l}4 \mathrm{C}, 0.2 \mathrm{~N} \\
1.6 \mathrm{~W}\end{array}$ & $\begin{array}{l}\text { Port Washington } \\
\text { W.D. }\end{array}$ & $\begin{array}{l}\text { Port Washing- } \\
\text { ton. }\end{array}$ & -...-. & 10 & 28 & 104 & $56-86 \ldots$ \\
\hline 6088 & $\begin{array}{c}2 \mathrm{~B}, 1.9 \mathrm{~N}, \\
1.0 \mathrm{~W}\end{array}$ & $\begin{array}{l}310 \text { Northern } \\
\text { Blvd. Corp. }\end{array}$ & Great Neck..... & 1957 & 6 & 112 & 104 & $98-103 \ldots$ \\
\hline $6089 ' T$ & $\begin{array}{l}3 \mathrm{C}, 2.5 \mathrm{~N} \\
0.8 \mathrm{~W}\end{array}$ & $\begin{array}{l}\text { Port Washington } \\
\text { W.D. }\end{array}$ & $\begin{array}{l}\text { Port Washing- } \\
\text { ton. }\end{array}$ & 1956 & 6 & 157 & 456 & \\
\hline $6095 \mathrm{~T}$ & $\begin{array}{l}4 \mathrm{C}, 0.5 \mathrm{~N} \\
1.2 \mathrm{~W}\end{array}$ & 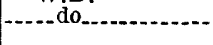 & .... do & 1957 & 6 & 110 & 415 & \\
\hline 6116 & $3 \mathrm{C}, 2.5 \mathrm{~N}$ & U.S.G.S.... & ..... do_..... & 1957 & $11 / 4$ & 157.3 & 74 & $72-74 \ldots$ \\
\hline 6117 & $\begin{array}{c}3 \mathrm{C}, 2.5 \mathrm{~N} \\
0.8 \mathrm{~W}\end{array}$ & -....do do & .....do... & 1957 & $11 / 4$ & 156.7 & 129 & $127-129$ \\
\hline
\end{tabular}


Nassau and northeastern Queens Counties, N.Y.-Continued

\begin{tabular}{|c|c|c|c|c|c|c|c|c|}
\hline \multirow{2}{*}{ 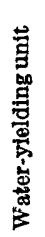 } & \multirow{2}{*}{ 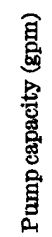 } & \multirow[b]{2}{*}{ 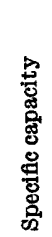 } & \multirow[b]{2}{*}{ 号 } & \multicolumn{2}{|c|}{ Water level } & \multicolumn{2}{|c|}{ Chloride } & \multirow[b]{2}{*}{ Remarks } \\
\hline & & & & 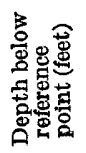 & Date & 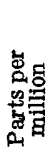 & Date & \\
\hline
\end{tabular}

\section{COUNTY}

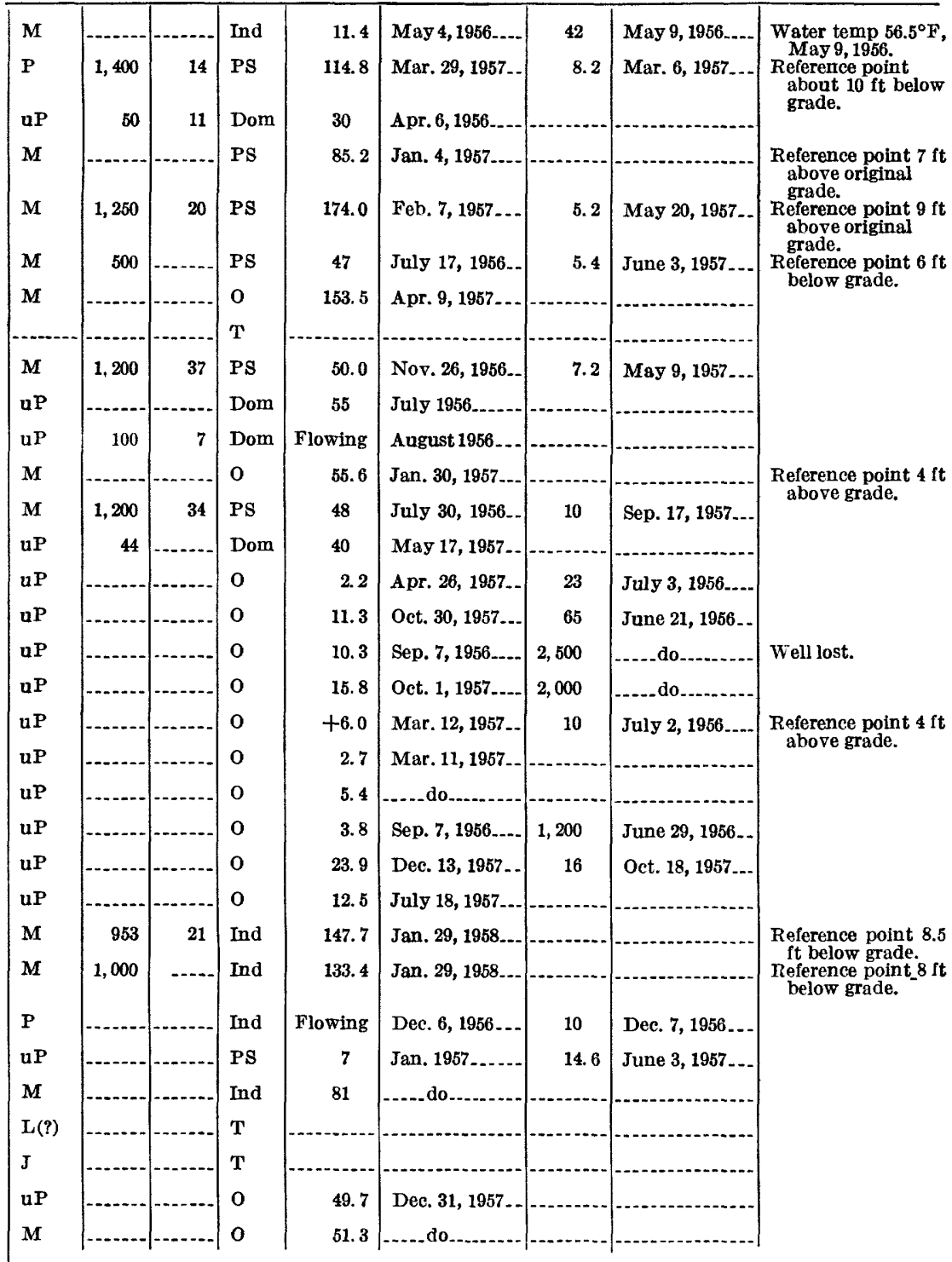


TABLE 11.-Records of selected wells in northwestern

\begin{tabular}{|c|c|c|c|c|c|c|c|c|}
\hline Well & $\underset{\text { coordinates }}{\text { Map }}$ & Owner & Location & 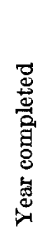 & 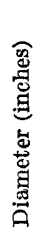 & 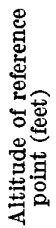 & 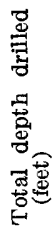 & $\begin{array}{c}\text { Screen } \\
\text { setting } \\
\text { below land } \\
\text { surface } \\
\text { (feet) }\end{array}$ \\
\hline
\end{tabular}

NASSAU

\begin{tabular}{|c|c|c|c|c|c|c|c|c|}
\hline N6118 & $4 \mathrm{C}, 0.5 \mathrm{~N}$, & U.S.G.S._. & Port Washing- & 1957 & 11,4 & 110.9 & 99 & $97-99$ \\
\hline 6119 & $2 \mathrm{D}, 1.3 \mathrm{~N}$, & Abilities, Inc...-..- & $\begin{array}{l}\text { ton. } \\
\text { Searington....... }\end{array}$ & 1957 & 12 & 115.5 & 196 & $156-181$ \\
\hline 6132 & $\begin{array}{l}4 \mathrm{C}, 0.1 \mathrm{~N} \\
1.7 \mathrm{~W}\end{array}$ & $\begin{array}{l}\text { Meadow Brook } \\
\text { National Bank. }\end{array}$ & $\begin{array}{l}\text { Port Washing- } \\
\text { ton. }\end{array}$ & 1957 & 2 & 10 & 37 & $33-37 \ldots$ \\
\hline 6160 & $3 \mathrm{D}, 1.7 \mathrm{~N}$, & Wm. J. McCor- & _o do & 1956 & $4-2$ & 42.0 & 315 & $85-90$ \\
\hline 6282 & $\begin{array}{l}4 \mathrm{C}, 1.6 \mathrm{~N} \\
1.8 \mathrm{~W}\end{array}$ & U.S.G.S & Sands Point..... & 1957 & 6 & 99.0 & 442 & $384-394$ \\
\hline 6290 & $3 \mathrm{C}, 2.1 \mathrm{~N}$ & $\ldots$ do & Port Washing- & 1957 & $1 \frac{1}{4}$ & 43.6 & 35 & $33-35$ \\
\hline 6291 & $3 \mathrm{C}, 2.0 \mathrm{~N}$ & ..... do... & ton. & 1957 & $11 / 4$ & 110.7 & 55 & $53-55$ \\
\hline 6292 & $3 \mathrm{D}, 1,1 \mathrm{~N}$, & ..._do_.. & ..... do & 1957 & $11 / 4$ & 77.6 & 53 & $51-53$ \\
\hline 6293 & $4 \mathrm{C}, 0.9 \mathrm{~N}$ & $\ldots d o_{\ldots}$ & ................ & 1957 & $1 \frac{1}{4}$ & 53.2 & 28 & $26-28$ \\
\hline 6295 & $3 \mathrm{~B}, 1.2 \mathrm{~N}$ & - & Kings Point & 1957 & $11 / 4$ & 53. 7 & 39 & $37-39$ \\
\hline 6316 & $\begin{array}{c}4 \mathrm{D}, 0.3 \mathrm{~N}, \\
2.0 \mathrm{~W}\end{array}$ & $\begin{array}{l}\text { W. Gotham Sand } \\
\text { \& Stone Co. }\end{array}$ & $\begin{array}{l}\text { Port Washing- } \\
\text { ton. }\end{array}$ & 1957 & 6 & 16.7 & 50 & $43-48$ \\
\hline 6333 & $\begin{array}{c}3 \mathrm{D}, 1.7 \mathrm{~N}, \\
0.4 \mathrm{~W}\end{array}$ & A. Cohen & Roslyn Harbor.. & 1957 & 6 & 150 & 142 & $131-142$ \\
\hline 6341 & $\begin{array}{l}4 \mathrm{C}, 1.6 \mathrm{~N}, \\
1.8 \mathrm{~W}\end{array}$ & U.S.G.S & Sands Point..... & 1957 & 1 & 97.8 & 89 & $86-89$ \\
\hline 6342 & $4 \mathrm{C}, 1.6 \mathrm{~N}$ & ............. & _._. do & 1957 & $11 / 1$ & 97.9 & 185 & $183-185$ \\
\hline 6346 & $\begin{array}{c}1.8 \mathrm{~W} \\
3 \mathrm{D}, 2.4 \mathrm{~N} \\
2.0 \mathrm{~W}\end{array}$ & $\begin{array}{l}\text { Colonial Sand \& } \\
\text { Stone Corp. }\end{array}$ & $\begin{array}{l}\text { Port Washing- } \\
\text { ton. }\end{array}$ & 1957 & 6 & 54.3 & 380 & $365-375$ \\
\hline 6351 & $4 \mathrm{C}, 0.7 \mathrm{~N}$, & U.S.G.S & ....do_..... & 1957 & 2 & 50.8 & 29 & $27-29$ \\
\hline $6416 \mathrm{~T}$ & $\begin{array}{l}4 \mathrm{D}, 1.8 \mathrm{~N}, \\
0.7 \mathrm{~W}\end{array}$ & $\begin{array}{l}\text { Zara Construc- } \\
\text { tion Co. }\end{array}$ & Glen Cove.- & 1958 & 6 & 10 & 295 & \\
\hline 6460 & $3 \mathrm{~B}, 0.4 \mathrm{~N}$ & U.S.G.S & Great Neck.... & 1958 & 2 & 57.3 & 47 & $45-47 \ldots$ \\
\hline $6489 \mathrm{D}$ & $\begin{array}{c}3 \mathrm{~B}, 1.0 \mathrm{~N} \\
1.4 \mathrm{~W}\end{array}$ & H. C. Bohack Co_ & .._do_... & 1954 & 4 & 86 & 115 & $110-115$ \\
\hline
\end{tabular}

QUEENS

\begin{tabular}{|c|c|c|c|c|c|c|c|c|}
\hline Q276 & $2 \mathrm{~B}, 0.2 \mathrm{~N}$, & N.Y.C.D.W.S.G. & Douglaston_.. & 1930 & $26-18$ & 26.7 & 531 & $185-211 \ldots$ \\
\hline 277 & $2, \mathrm{~B}, 0.4 \mathrm{~N}$. & $\& \mathbb{E}$ & $\ldots$ do_... & 1930 & 18 & 16.0 & 152 & $114-144 \ldots$ \\
\hline 278 & $\begin{array}{c}2 \mathrm{~B}, 0.4 \mathrm{~N} \\
1.8 \mathrm{~W}\end{array}$ & _-_do & _ & 1930 & $26-12$ & 16.0 & 512 & $\begin{array}{l}380-400 \\
427-447\end{array}$ \\
\hline 321 & $\underset{2,0 \mathrm{~W}}{1 \mathrm{~B}, 0.4 \mathrm{~N}}$ & Jam. W. s. C.... & Queens Village... & 1931 & 18 & 138.6 & 152 & $130-145 \ldots$ \\
\hline 402 & $2 \mathrm{~A}, 0.9 \mathrm{~N}$, & N.Y.C. Dept. of & Bayside.. & & & 10 & 65 & \\
\hline 470 & $2 \mathrm{~A}, 0.8 \mathrm{~N}$, & N.Y.C.D.W.S.G. & .......do_... & 1911 & $8-6$ & 14.1 & 379 & $349-375 \ldots$ \\
\hline 471 & $\begin{array}{c}2 \mathrm{~A}, 0.8 \mathrm{~N}, \\
0.4 \mathrm{~W}\end{array}$ & 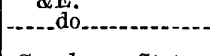 & .....do_... & 1911 & $8-6$ & 18.5 & 117 & $\begin{array}{l}\text { Bottom at } \\
\text { 117. }\end{array}$ \\
\hline 577 & $\begin{array}{l}1 \mathrm{~B}, 0.9 \mathrm{~N}, \\
1.0 \mathrm{~W}\end{array}$ & $\begin{array}{l}\text { Creedmoor State } \\
\text { Hospital. }\end{array}$ & Bellrose_. & & $12-8$ & 114.5 & 700 & \\
\hline 580 & $\begin{array}{c}1 \mathrm{~B}, 0.9 \mathrm{~N}, \\
1.0 \mathrm{~W}\end{array}$ & - & $\ldots \mathrm{do}_{-.}$ & 1932 & 12 & 119.2 & 680 & $661-680 \ldots$ \\
\hline 581 & $\begin{array}{c}1 \mathrm{~B}, 0.9 \mathrm{~N}, \\
1.0 \mathrm{~W} .\end{array}$ & -....do... & $\ldots$ do & & 12 & 115.5 & 690 & $672-688$ \\
\hline
\end{tabular}


Nassau and northeastern Queens Counties, N.Y.-Continued

\begin{tabular}{|c|c|c|c|c|c|c|c|c|}
\hline \multirow{2}{*}{ 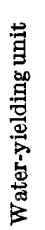 } & \multirow{2}{*}{ 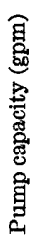 } & \multirow[b]{2}{*}{ 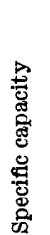 } & \multirow[b]{2}{*}{$\begin{array}{l}\mathscr{D} \\
\ddot{B}\end{array}$} & \multicolumn{2}{|c|}{ Water level } & \multicolumn{2}{|c|}{ Chloride } & \multirow{2}{*}{$\begin{array}{c}! \\
\text { Remarks }\end{array}$} \\
\hline & & & & 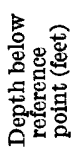 & Date & 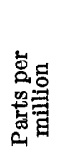 & Date & \\
\hline
\end{tabular}

\section{COUNTY}

\begin{tabular}{|c|c|c|c|c|c|c|c|c|}
\hline $\mathbf{u P}$ & $\cdots$ & $-\ldots$ & $\mathbf{O}$ & 74.0 & Dec. $31,1957 \ldots$ & - n-n-n & 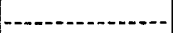 & \\
\hline $\mathbf{M}$ & 300 & - - - & Ind & 46.8 & May $14,1957 .-$ & & -2-n-nen & Reference point 7 \\
\hline $\mathfrak{u P}$ & 20 & & Ind & 7 & Feb. 1957 & 100 & May 14,1957 & \\
\hline $\mathbf{M}$ & $\ldots \ldots$ & & Ind & 19 & Jan, 1957 & 190 & Oct. 1,1957 & \\
\hline $\mathbf{J}$ & 100 & 2 & 0 & 91.5 & Dec. 31, 1957..- & 5.4 & Aug. $23,1957 \ldots$ & $\begin{array}{l}\text { (4), (5), (7). Water } \\
\text { t3mp } 55^{\circ} \text { F, Aug. } \\
\text { 23, 1957. }\end{array}$ \\
\hline $\mathfrak{u P}$ & $\ldots$ & & $\mathbf{0}$ & 29.3 & Dec. $13,1957 \ldots$ & 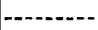 & $m-2-2-2-2 x-2$ & \\
\hline $\mathfrak{u P}$ & & & 0 & 14. 9 & Oct. $1,1957 \ldots$ & & 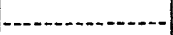 & (7). \\
\hline $\mathbf{M}$ & & & 0 & 45.4 & Oct. 30,1957 & 28 & Oct. $18,1957 \ldots$ & \\
\hline $\mathbf{u P}$ & & & 0 & 23.8 & Dec. $31,1957 \ldots$ & -.enten & & \\
\hline $\mathbf{u P}$ & & & $\mathrm{O}$ & 6.7 & Dec. $13,1957_{--}$ & & & \\
\hline $\mathbf{n P}$ & & & Ind & 15.0 & Sep. 4, 1957-..- & 160 & Sep. 11, 1957 & \\
\hline $\mathbf{P}$ & & & Dom & 91.7 & Sep. 6, 1957_..- & $-\infty-\infty$ & - & Water temp $55.5^{\circ} \mathrm{F}$, \\
\hline $\mathbf{u P}$ & & & $\mathbf{O}$ & 78.1 & Dec. $31,1957 \ldots$ & & & \\
\hline$G$ & & & 0 & 78.4 & ............ & & & \\
\hline $\mathbf{L}$ & 80 & 2 & Ind & 39.1 & Nov. $4,1957 \ldots$ & 4.9 & Oct. $22,1957 \ldots$ & $\begin{array}{l}\text { Ch) Chlorides } \\
2,550 \text { ppm at } \\
\text { cepth of } 52 \mathrm{ft} . \\
\text { ater temp } 55^{\circ} \mathrm{F} \\
\text { Oct. } 22,1957 .\end{array}$ \\
\hline $\mathbf{u P}$ & & & 0 & 20.2 & Dec. $31,1957 \ldots$ & 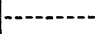 & -- & \\
\hline $\mathbf{L}$ & & & $\mathbf{T}$ & & natan & - & n-mon & \\
\hline uP & & & 0 & 36. 9 & May 28, 1958.- & $\ldots$ & $\ldots$ & \\
\hline $\mathbf{u P}$ & & & Ind & 65 & $1954 \ldots \ldots$ & $\ldots$ & -nenten & $\begin{array}{l}\text { Water temp } 54^{\circ} \mathrm{F} \text {, } \\
1^{0} 54 .\end{array}$ \\
\hline
\end{tabular}

\section{COUNTY}

\begin{tabular}{|c|c|c|c|c|c|c|c|c|}
\hline $\mathbf{M}$ & $---\infty$ & -....... & $\mathbf{A}$ & 1.8 & Aug. 8, 1956... & 7.0 & May $9,1933 \ldots$ & (5), (7), (8). Lost \\
\hline $\mathbf{M}$ & & & PS & Flowing & Feb. 3, 1956... & 15 & July $6,1949 \ldots$ & $(8)$ \\
\hline $\mathbf{L}$ & --.-- & & PS & 7.2 & Mar. 31, 1955.. & 7.9 & $1940 \ldots$ & (5), (8). \\
\hline $\mathbf{u P}$ & 860 & 37 & PS & 113 & Dec. 21, 1957.- & 16 & $1940 \ldots \ldots$ & \\
\hline & & & $T$ & & 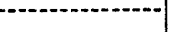 & & & \\
\hline L & $\ldots$ & & 0 & 9.9 & Dec. $20,1957 \ldots$ & & & \\
\hline $\mathbf{M}$ & $-\cdots$ & & o & 2.6 & .....do........... & & & Reference point $4 \mathrm{ft}$ \\
\hline $\mathbf{L}$ & 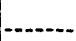 & & 0 & 111. 0 & Jan. 27, 1958_..- & & & \\
\hline $\mathbf{L}$ & 465 & & Dom & 122.5 & Feb. 15, 1950_. & 3.4 & Feb. 28, 1952_- & \\
\hline $\mathbf{L}$ & 505 & ......... & Dom & 125 & Feb. 16, 1950_- & 4.0 & May $19,1950 .-$ & \\
\hline
\end{tabular}


TABLE 11.-Records of selected wells in northwestern Nas-

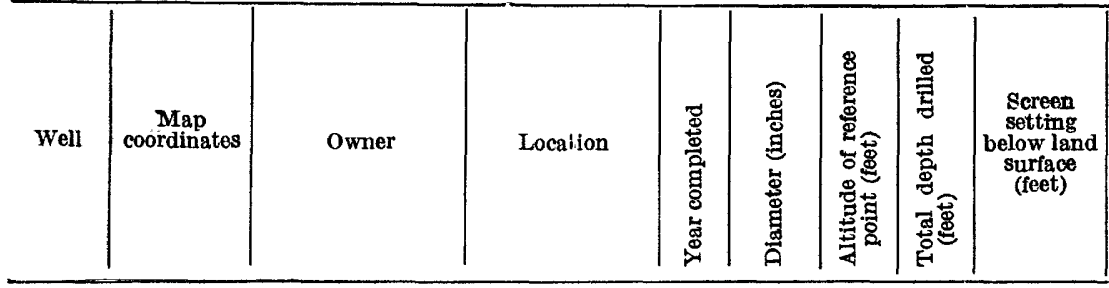

QUEENS

\begin{tabular}{|c|c|c|c|c|c|c|c|c|}
\hline 582 & $1 \mathrm{~B}, 0.9 \mathrm{~N}$ & Creedmoor State & Bellrose......... & & $12-8$ & 110.4 & 686 & 670-686.... \\
\hline 1293 & $1 \mathrm{~B}, 0.9 \mathrm{~N}$ & .....do do & .....do do & 1941 & $12-8$ & 115. 2 & 680 & $644-667$ \\
\hline 1479 & $\begin{array}{l}1 \mathrm{~B}, 0.3 \mathrm{~N}, \\
1.9 \mathrm{~W}\end{array}$ & $\begin{array}{l}\text { Fairchild Sons, } \\
\text { Inc. }\end{array}$ & Queens Village.- & 1948 & 8 & 110 & 124 & $104-120$ \\
\hline $1603 \mathrm{D}$ & $\begin{array}{c}1 \mathrm{~B}, 1.4 \mathrm{~N} \\
0.2 \mathrm{~W}\end{array}$ & $\begin{array}{l}\text { Gross-Morton, } \\
\text { Inc. }\end{array}$ & Glen Oaks.. & 1949 & 8 & 114.3 & 95 & $73-85 \ldots$ \\
\hline 1695 & $\begin{array}{l}2 \mathrm{~B}, 1.4 \mathrm{~N} \\
1.5 \mathrm{~W}\end{array}$ & $\begin{array}{l}\text { Queens County } \\
\text { Savings Bank. }\end{array}$ & Little Neck...... & 1950 & $6-4$ & 85 & 186 & $168-179$ \\
\hline 1700 & $\begin{array}{c}2 \mathrm{~A}, 0.4 \mathrm{~N} \\
0.7 \mathrm{~W}\end{array}$ & $\begin{array}{l}\text { Jeffrey Garden } \\
\text { Apts. }\end{array}$ & Bayside.. & 1950 & $8-6$ & 64 & 77 & 66-77.. \\
\hline 1719 & $\begin{array}{c}2 \mathrm{~A}, 0.05 \mathrm{~N}, \\
0.3 \mathrm{~W} .\end{array}$ & $\begin{array}{l}\text { Oakland Golf } \\
\text { Club. }\end{array}$ & ......do_. & 1950 & 8 & 94. 7 & 86 & $81-96 \ldots$ \\
\hline 1797 & $1 \mathrm{~A}, 1,1 \mathrm{~N}$ & Food Fair Stores, & .................. & 1951 & 6 & 99 & 110 & $93-104 \ldots$ \\
\hline 1809 & $\begin{array}{l}2 \mathrm{~B}, 0.3 \mathrm{~N} \\
0.05 \mathrm{~W}\end{array}$ & $\begin{array}{l}\text { Long Island } \\
\text { Jewish Hospital. }\end{array}$ & Glen Oaks. & 1952 & 12 & 132 & 250 & 204-244. \\
\hline 1914 & $\begin{array}{l}1 \mathrm{~B}, 0.9 \mathrm{~N} \\
1.0 \mathrm{~W}\end{array}$ & $\begin{array}{l}\text { Creedmoor State } \\
\text { Hospital. }\end{array}$ & Bellrose.... & 1952 & $14-8$ & 108 & 258 & 232-258... \\
\hline 1937 & $\begin{array}{l}2 \mathrm{~A}, 0.8 \mathrm{~N} \\
\text { 1.0W. }\end{array}$ & $\begin{array}{l}\text { New York Tele- } \\
\text { phone Co. }\end{array}$ & Bayside_............ & 1953 & 8 & 65 & 83 & $62-78 \ldots$ \\
\hline
\end{tabular}

TABLE 12.-Logs of selected wells in northwestern Nassau and northeastern Queens Counties, N.Y.

[Stratigraphic correlations by U.S. Geol. Survey personnel. Altitudes approximate. Reference datum: Mean sea level, Sandy Hook, N.J.]

\begin{tabular}{l|l}
\hline Thickness \\
(feet)
\end{tabular} \mid $\begin{gathered}\text { Depth } \\
\text { (feet) }\end{gathered}$

\section{NASSAU COUNTY}

$\mathrm{N} 2400$

[Roslyn Water District, Locust Lane, Roslyn, N.Y (2D, 2.5N, 0.5W). Drilled 1947 by Layne-New York Co., Inc. Screen 399-439 ft; alt $166 \mathrm{ft}$. Driller's log]

Pleistocene deposits, undifferentiated:

Sand and boulders

Sand, boulders, and gravel

Magothy(?) formation:

Sand and streaks of clay.....

Sand and clay

Sand and clay streaks

Clay, tough...

Sand, medium, gray, muddy

Clay, sandy

Sand, medium.

Clay, tough...

Sand, coarse, and gravel

Gravel and clay

Raritan formation:

Clay member:

$$
\text { Clay, tough }
$$


sau and northeastern Queens Counties, N.Y.-Continued

\begin{tabular}{|c|c|c|c|c|c|c|c|c|}
\hline \multirow{2}{*}{ 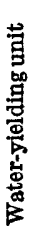 } & \multirow{2}{*}{ 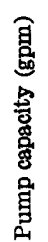 } & \multirow[b]{2}{*}{ 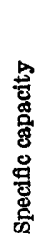 } & \multirow[b]{2}{*}{ 兽 } & \multicolumn{2}{|c|}{ Water level } & \multicolumn{2}{|c|}{ Chloride } & \multirow[b]{2}{*}{ Remarks } \\
\hline & & & & 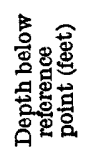 & Date & 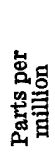 & Date & \\
\hline
\end{tabular}

\section{COUNTY}

\begin{tabular}{|c|c|c|c|c|c|c|c|c|}
\hline $\mathbf{L}$ & 640 & 7 & Dom & 104 & Feb. 16, 1950_. & 3.6 & $1953 \ldots$ & \\
\hline $\mathbf{L}$ & 500 & 7 & Dom & $\ldots . .115$ & _...do do_....... & 4.0 & Feb. 28, 1952.. & \\
\hline $\mathbf{u P}$ & 100 & $\ldots$ & Ind & 75 & July 26, 1948... & - - - - & & \\
\hline $\mathbf{u P}$ & $\ldots$ & & Ind & 62.7 & Apr. $22,1957 \ldots$ & & & $(7,$. \\
\hline $\mathbf{M}$ & 50 & 5 & Ind & 68 & May $17,1950 \ldots$ & & & (4). \\
\hline $\mathbf{u P}$ & 73 & -....... & Dom & 40.6 & May $24,1957$. & $\ldots$ & & Reference point $5 \mathrm{ft}$ \\
\hline $\mathbf{u P}$ & 250 & 22 & Irr & 68.2 & July $7,1950 \ldots$ & & & \\
\hline $\mathbf{u P}$ & 120 & 12 & Ind & 71 & Aug. 16, 1951.. & & & \\
\hline $\mathbf{M}$ & 830 & 30 & Dom & 78 & Oct. 2, 1952...- & & & (4). \\
\hline $\mathbf{M}$ & 500 & $-\ldots$ & Dom & 68.0 & May 24, 1957... & & & Reference point $6 \mathrm{ft}$ \\
\hline $\mathbf{u P}$ & 360 & 26 & Ind & 44 & Aug. 10, 1953.. & - & & \\
\hline
\end{tabular}

TABLE 12.-Logs of selected wells in northwestern Nassau and northeastern Queens Counties, N.Y.-Continued

\begin{tabular}{|c|c|c|}
\hline & $\underset{\text { (feet) }}{\text { Thick }}$ & $\begin{array}{l}\text { Depth } \\
\text { (feet) }\end{array}$ \\
\hline $\begin{array}{c}\text { N2569T } \\
\text { [New York State Department of Public Works, Roslyn Viaduct, } 726 \mathrm{ft} \text { east of } \\
\text { N.Y. (3D, 0.8N, 1.5W). Test boring 1943; alt } 8 \mathrm{ft} \text {. Driller's }\end{array}$ & $\begin{array}{l}\text { West Ak } \mathrm{Altm} \\
\log ]\end{array}$ & t, Roslyn, \\
\hline $\begin{array}{l}\text { Recent deposits: } \\
\text { Sand and muck } \\
\text { Sand, gravel and muck }\end{array}$ & $\begin{array}{l}17 \\
10\end{array}$ & $\begin{array}{l}17 \\
27\end{array}$ \\
\hline Pleistocene deposits, undifferentiated: & 10 & \\
\hline Sand, brown, and gravel, and layers of brown clay & 22 & $\begin{array}{l}49 \\
56\end{array}$ \\
\hline Sand, fine, brown, and clay & at & 69 \\
\hline $\begin{array}{l}\text { Sand, fine, red-brown, some clay and mica flakes } \\
\text { Sand, fine, gray-brown, some clay and mica flakes }\end{array}$ & $\underset{70}{5}$ & $\begin{array}{r}74 \\
152\end{array}$ \\
\hline Sand, fine, gray-brown, some clay and mica Hakes & 78 & 152 \\
\hline
\end{tabular}


TABLE 12.-Logs of selected wells in northwestern Nassau and northeastern Queens Counties, N.Y.-Continued

\begin{tabular}{l|l|l}
\hline Thickness & $\begin{array}{c}\text { Depth } \\
\text { (feet) }\end{array}$ \\
\hline
\end{tabular}

\section{N2635}

[Nassau County Department of Public Works, South Washington St., Port Washington, N.Y. (3C, $2.5 \mathrm{~N}, 1.6 \mathrm{~W})$. Drilled 1948 by Nassau County Department of Public Works. Slotted 150-154 ft; alt $40 \mathrm{ft}$. Log based on examination of bailer samples by C. M. Roberts]

Recent deposits:

Top soil, dark brown, sandy

Pleistocene deposits, undifferentiated:

Loam, brown, gravelly

Sand, coarse, brown, and gravel

Sand, medium, light brown and some brown clay in streaks

Clay, green, blue, and yellow, with thin streaks of fine sandy clay

Clay, sandy, greenish-brown

Sand, medium, light brown, and some brown clay streaks -

Sand, medium, dark gray, some clay -

Clay, steel gray, containing many oyster shells; some small gravel.

Sand, medium, brown; mica and gray clay, sandy; some shells

Sand, fine, brown, and silt; some small pebbles and a few shell fragments.

Sand, fine, brown, silty and clayey

Clay, tough, dark brown, with some quartz pebbles

Sand and gravel, coarse, brown, with some brown clay.

Gravel, coarse, and coarse brown sand.

Sand, medium to coarse, brown, and some gravel

Clay, tough, dark brown, sandy near bottom

Clay, gray and brown, hard and some gravel...

Sand, coarse and gravel; little gray clay

Sand, fine to medium, gray, and mixed sizes of gravel and gray sandy clay Magothy(?) formation:

Sand, medium to coarse, gray, with mixed sizes of gravel-

Sand, fine to medium, light gray; some grits .

Clay, brown, sandy with much fine mica. 
TABLE 12.-Logs of selected wells in northwestern Nassau and northastern Queens Counties, N.Y.-Continued

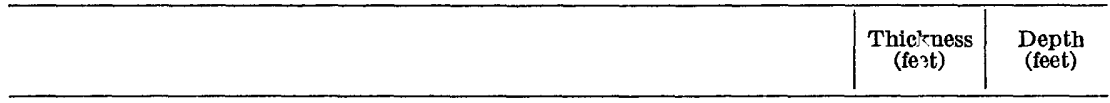

\section{N3521T}

[Village of Plandome, 1,500 ft south of Plandome Station, Plandome, N.Y. (3C, 1.1IT, 1.6W). Drilled 1950 by C. W. Lauman \& Co., Inc. (cored test hole); alt about $50 \mathrm{ft}$. Driller's log]

Recent deposits:

Loam

Pleistocene deposits, undifferentiated:

Clay, solid gray

Sand, coarse, brown, and grits

Clay, solid, gray (varved and laminated)

Sand, coarse, gray; grits and some gravel

Sand, coarse, brown; grits and some gravel

Gravel, packed with clay, very hard formation

Sand, medium to coarse, brown; large gravel, packed very hard

Sand, fine, brown

Raritan formation:

Clay member:

Clay, solid, gray, and lignite

Lloyd sand member:

Sand, fine, brown, and clay

Sand, fine, brown, and some clay

Sand, coarse, brown; fine gravel

Sand, coarse, brown; clay, grit, gravel

Clay, solid, brown

Sand, fine, brown (dirty)

Sand, medium to coarse, brown

Sand, coarse, brown, and grits 
TABLE 12.-Logs of selected wells in northwestern Nassau and northeastern Queens Counties, N.Y.-Continued

\begin{tabular}{l|l|l}
\hline & $\begin{array}{c}\text { Thickness } \\
\text { (feet) }\end{array}$ & $\begin{array}{c}\text { Depth } \\
\text { (feet) }\end{array}$ \\
\hline
\end{tabular}

\section{N3905}

[Manhasset-Lakeville Water District, Northern State Parkway, Lake Success, N.Y. (2C, 0.9N, 1.6W). Drilled 1952 by Layne-New York Co., Inc. Screen 212-252 ft; alt $130 \mathrm{ft}$. Driller's log]

Pleistocene deposits, undifferentiated:

Clay

Boulders

Hardpan and boulders

Sand, gravel, and boulders

Sand, gravel, and hard streaks

Magothy (?) formation:

Clay, yellow, soft

Sand and streaks of gray clay

Clay, gray, and streaks of sand

Sand and clay, hard packed

Sand and gravel

Clay

Sand and streaks of clay and gravel, reddish-brown

Sand, coarse, and reddish-brown gravel

Hard streak.

Clay

Sand, gravel, and clay, in streaks

Clay, white, soft, sandy.

Clay, hard

Sand, white clay streaks

Sand, clay, and hard streaks

Gravel and clay, very hard streaks

Raritan formation:

Clay member:

Clay, gray, hard

Clay, black and gray, and wood

Clay, gray, and hard streaks

Clay, black

Lloyd sand member:

Sand, hard packed

Sand.

Clay, white

Sand and gravel; some clay

Clay, hard

Bedrock:

Sand, gravel, and clay

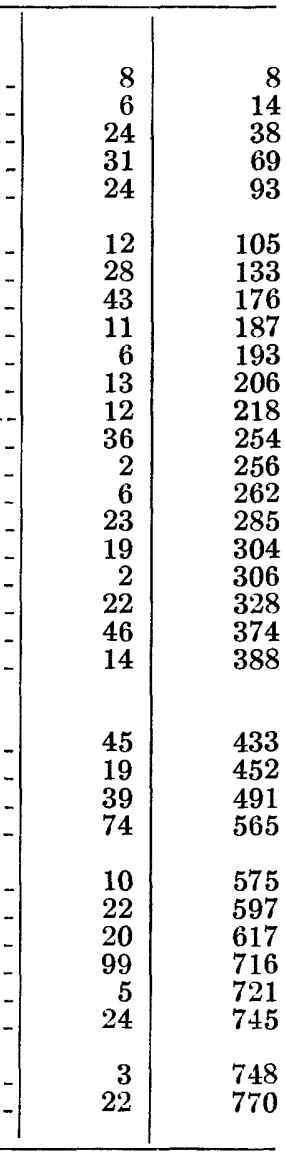

Clay

Bedrock 
TABLE 12.-Logs of selected wells in northwestern Nassau and northeastern Queens Counties, N.Y.-Continued

\begin{tabular}{l|l|l}
\hline & $\substack{\text { Thick ness } \\
\text { (feet) }}$ & $\begin{array}{c}\text { Depth } \\
\text { (feet) }\end{array}$ \\
\hline
\end{tabular}

\section{N4223}

[Port Washington Water District, Port Washington Blvd., Port Washington, N.Y. (3C, 1.7N, 0.5W). Drilled 1953 by C. W. Lauman \& Co., Inc. Screen $277-330 \mathrm{ft}$; alt about $190 \mathrm{ft}$. Examination of cores (partly cored test hole) by N. M. Perlmutter and W. V. Swarzenski]

Recent deposits:

Topsoil

Upper Pleistocene deposits:

Loam, large gravel and boulders (till)

Sand, coarse, brown; grits, gravel, boulders (outwash) --

Sand, coarse, brown; large gravel and lumps of clay (outwash)

Sand, coarse, brown, and large gravel (outwash)

Clay, solid, gray

Sand and clay, medium coarse, gray, in layers

Clay, solid, gray, containing shell fragments (till)

Sand, medium coarse; grits and gravel (outwash)

Pleistocene deposits, undifferentiated:

Sand, fine, brown, and streaks of clay -

Clay, solid, brown, and sand in streaks (laminated)

Sand sod, brown, and sand in streaks (lamingte

Sand, fine, brown, and streaks of clay

Sand, medium fine, brown ........

Sand, medium coarse, brown; grits and gravel

Clay, solid, gray, streaks; medium coarse sand.

Sand, coarse, brown; grits, gravel, clay

Raritan formation:

Clay member:

Sand, fine, brown; sandy clay, solid clay

Sand, fine brown

Sand, fine, white; some clay

Sand, fine to medium, brown

Clay, solid, light gray; streaks of sandy clay.

Clay, fine, sandy, gray.

Sand, medium fine, brown; some clay

Clay, solid, multi-colored

Clay, sandy, pink

Clay, solid, multi-colored

Sand, medium to coarse, brow; hamdpan and clay

Sand and clay, brown.

Clay, solid, light gray.

\begin{tabular}{r|r} 
& \\
1 & 1 \\
10 & 11 \\
21 & 32 \\
7 & \\
7 & 39 \\
20 & 59 \\
9 & 68 \\
15 & 83 \\
18 & 101 \\
35 & 136 \\
& \\
29 & 165 \\
9 & 174 \\
12 & 186 \\
9 & 195 \\
4 & 199 \\
128 & 327 \\
4 & 331 \\
9 & 340 \\
& \\
6 & \\
5 & 346 \\
6 & 351 \\
13 & 357 \\
6 & 370 \\
5 & 376 \\
5 & 381 \\
35 & 386 \\
17 & 421 \\
38 & 438 \\
27 & 476 \\
4 & 503 \\
3 & 507 \\
& 510 \\
& \\
\hline
\end{tabular}


TABLE 12.-Logs of selected wells in northwestern Nassau and northeastern Queens Counties, N.Y.-Continued

\begin{tabular}{l|l}
\hline Thickness \\
(feet)
\end{tabular} \mid $\begin{gathered}\text { Depth } \\
\text { (feet) }\end{gathered}$

\section{N4266}

[U.S. Geol. Survey, Piccadilly Road, about $330 \mathrm{ft}$ east of Middle Neck Road, Great Neck. N.Y. (3B, $0.4 \mathrm{~N}, 1.3 \mathrm{~W})$. Observation well drilled 1954 by $\mathrm{C}$. W. Lauman \& Co., Inc. Screen 377-392 ft; alt about $56 \mathrm{ft}$. Geologist's log based on examination of core samples, electrical log, and driller's log by N. M. Perlmutter and H. G. Healy]

Recent and Pleistocene deposits:

Topsoil and loam (driller's log)

Pleistocene deposits, undifferentiated:

Sand, fine to coarse, brown, and gravel with some layers of clayey sand (flume sample)

Sand, very fine to fine, brown, silty and clayey, with thin layers of solid clay and medium to coarse sand

Clay, solid, gray, with layers of gray medium to coarse sand and sandy clay

Sand, fine to medium, brown, with some clay.

Clay, solid, gray and brown, with some thin layers of very fine sand and silt

Sand, fine to medium, brown

Clay, solid, brown and gray, with a trace of siltt.....

Sand, very fine to fine, gray-brown, with thin beds of silt and fine to medium sand.

Sand, fine to medium, brown

Sand, very fine, and silt, micaceous, brown

Sand, fine to medium, brown

Raritan formation:

Clay member:

Clay, solid gray and red, with some silty layers, lignite, and concretionary layer.....

Lloyd sand member:

Sand, very fine, brown, and silt.

Sand, fine to medium, gray; trace of clay, and a few thin layers of sandy clay

Clay, solid and silty, tan; thin streaks of clayey sand.

Sand, fine to medium, tan, with gravel, and trace of clay.

Sand, medium to very coarse, tan, some gravel, and thin layers of clay . .

Sand, fine, tan, with thin layers of tan clay

Sand, coarse, and gravel, clayey, tan, with some thin layers of solid clay .......

Sand, coarse, brown, and gravel

Clay, solid and silty, brown and gray, and layers of fine to medium sand.....

Clay, solid and silty, brown and gray Precambrian:

Sand, medium to coarse, brown, and gravel.....

Bedrock, weathered, yellow

Bedrock, weathered, gray, hard and soft zones 
TABLE 12.-Logs of selected wells in northwestern Nassau and northeastern Queens Counties, N.Y.-Continued

$\left|\begin{array}{c|c}\text { Thickness } \\ \text { (feet) }\end{array}\right| \begin{gathered}\text { Depth } \\ \text { (feet) }\end{gathered}$

\section{N4859T}

[Port Washington Water District, Sandy Hollow Road, Port Washington, N.Y. (4C, 0.2N, 1.5W). Drilled 1954 by Layne-New York Co., Inc. Test hole; alt about $25 \mathrm{ft}$. Driller's log]

Recent deposits:

Fill

Upper Pleistocene deposits:

Sand, coarse, brown; gravel

Sand, fine, brown

Clay, blue, sandy

Gardiners clay:

Clay, blue, soft (containing foraminifera)

Sand, fine, gray

Jameco gravel:

Clay, blue, steaks of gravel and wood

Gravel and sand

Clay and sand streaks

Bedrock:

Sand and gravel

Granite, decomposed

Rock, solid.

\begin{tabular}{r|r} 
& \\
4 & 4 \\
26 & 30 \\
25 & 55 \\
30 & 85 \\
& \\
83 & 168 \\
71 & 239 \\
41 & 280 \\
21 & 301 \\
48 & 349 \\
34 & 383 \\
& \\
15 & 398 \\
1 & 399 \\
&
\end{tabular}

N5530

[Port Washington Water District, Wysong Hollow, Port Washington, N.Y. (3C, 2.5N, 1.5W), Drilled 1955 by Layne-New York Co., Inc. Screen 372-382 ft; alt $63 \mathrm{ft}$. Driller's lig]

Recent deposits:

Fill

Upper Pleistocene deposits:

Sand, gravel and boulders

Sand and clay, old wood

Clay, red.

Clay, blue, tough

Clay, blue, and gravel

Gardiners clay:

Clay, red and brownish

Magothy(?) formation:

Sand, red, streaks of gravel

Raritan formation:

Clay member:

Clay, black and blue, and sand streaks

Sand rock ...

Sand, fine, white; clay balls and streaks of white clay

Clay, brown and white

Lloyd sand member:

Sand, coarse, white, and gravel

Clay, white

Sand, coarse, white, and gravel; some clay streaks.

Bedrock:

Clay, white

\begin{tabular}{r|r} 
& \\
3 & 3 \\
17 & 20 \\
30 & 50 \\
8 & 58 \\
45 & 103 \\
7 & 110 \\
63 & 173 \\
50 & 223 \\
& \\
33 & \\
2 & 256 \\
59 & 317 \\
3 & 320 \\
20 & 340 \\
2 & 342 \\
38 & 380 \\
7 & 387 \\
& \\
43 & 430 \\
6 & 436 \\
&
\end{tabular}

bedrock) . .

Rock 
TABLE 12.-Logs of selected wells in northwestern Nassau and northeastern Queens Counties, N.Y.-Continued

\begin{tabular}{r|c|c}
\hline & $\begin{array}{c}\text { Thickness } \\
\text { (feet) }\end{array}$ & $\begin{array}{c}\text { Depth } \\
\text { (feet) }\end{array}$ \\
\hline
\end{tabular}

N6282

[U.S. Geol. Survey, Middle Neck Road, Sands Point, N.Y. (4C, 1.6N, 1.8W). Drilled 1957 by C. W. Lauman \& Co., Inc. Screen 384-394 ft. Cored observation well; alt $97 \mathrm{ft}$. Log based or examination of flume samples, cores and electric log by W. V. Swarzenski]

Recent deposits:

Topsoil and loam

Upper Pleistocene deposits:

Sand, coarse, brown; gravel; pebbles up to 2 in. (till and outwash)

Sand, medium, brown
Sand, fine, gray and brown

Gardiners clay:

Sand, very fine to fine, gray; small amount of clay; some lignite.

Sand, very fine,

Clay, solid, grayish-brown; laminated, very small fraction of silt

Sand, clayey, brown; pebibles and boulders (granite boulder 237 to $239 \mathrm{ft}$ )

Clav, solid, brown; laminated, very small fraction of silt.

Clay, solid, gray; laminated, very small fraction of silt.-

Sand, very fine to fine, silty and clayey, gray; some lignite.

Jameco gravel:

Sand, medium to coarse, light brown, clean .

Sand, fine, gray and seams of silty and clayey sand...-

Sand, medium to coarse, gray, clean .......

Sand, very fine to fine, gray; little clay Bedrock:

Sand, medium to coarse, gray and seams of gray silty clay -

Biotite schist, weathered.

\begin{tabular}{|c|c} 
& \\
3.5 & 3.5 \\
& \\
109.5 & 113 \\
9 & 124 \\
& 133 \\
& \\
59 & 192 \\
11 & 203 \\
27 & 230 \\
12 & 242 \\
26 & 268 \\
29 & 297 \\
41 & 338 \\
& \\
8 & 346 \\
30 & 376 \\
21 & 397 \\
7 & 404 \\
16 & 420 \\
22 & 442 \\
& \\
\hline
\end{tabular}

\section{QUEENS COUN'TY}

Q1695

[Queens County Savings Bank, Northern Blvd., Little Neck, N.Y. (2B, 1.4N, 1.5W). Drilled 1950 by Mathies Well \& Pump Co., Inc. Screen 168-179 ft; alt about 85 ft.' Driller's log]

Pleistocene deposits, undifferentiated:

Cellar.

Sand, medium, brown

Sand, coarse, brown; grits, gravel, large stones

Sand, medium, brown; large amount of brown clay ..... Magothy(?) formation: 1

Clay, white

Clay, white; fine sand

(n)

Clay, brown, and coarse sand

Sand, medium, brown, and brown clay

Sand, medium, brown, and small grits

Sand, fine, white; small grits

Sand and gravel

\begin{tabular}{r|r} 
& \\
10 & 10 \\
3 & 13 \\
47 & 60 \\
29 & 89 \\
& \\
3 & 92 \\
3 & 95 \\
14 & 109 \\
17 & 126 \\
19 & 145 \\
3 & 148 \\
21 & 169 \\
17 & 186 \\
&
\end{tabular}

I Precise depth of contact uncertain. 
TABLE 12.-Logs of selected wells in northwestern Nassau and northeastern Queens Counties, N.Y.-Continued

\begin{tabular}{l|l|l}
\hline & $\substack{\text { Thickness } \\
\text { (feet) }}$ & $\begin{array}{c}\text { Depth } \\
\text { (feet) }\end{array}$ \\
\hline
\end{tabular}

Q1909

[Long Island Jewish Hospital, 270th St. and 76th Ave., Glen Oaks, N.Y. (2B, 0.3N, 0.05W). Drilled 1952 by $C$. W. Lauman \& Co., Inc. Screen $204-244 \mathrm{ft}$; alt about $132 \mathrm{ft}$. Dril'er's log]

Upper Pleistocene deposits:

Outwash:

Pit, pump.

Sand and gravel, coarse.

Sand and gravel, coarse; boulders

Sand and gravel, coarse

Sand and gravel, medium coarse

Sand, coarse, and large stones

Sand and gravel, coarse

Sand, coarse; grits, large gravel and stone

Sand, fine, brown; grits and gravel

Magothy(?) formation:

Sand, fine, gray, and gray clay

Sand, fine, white; fine streaks of clay

Sand, fine, white; some grits

Sand, fine, white, and streaks of clay

Clay, fine, brown, sandy

Sand, medium coarse, gray, and grits

Sand, medium coarse, and hardpan

Clay, gray, sandy

Sand, very fine, gray, and hardpan; some clay

Sand, very fine, gray; some clay

Sand, fine, gray; some grits and clay

Clay, fine, gray, sandy

Sand, fine, gray, and grits

Sand, fine, gray, and hardpan

Sand, fine, gray, and hardpan; some clay

Sand, very fine, gray

Clay, gray, solid.....-

Clay, gray, sandy

\begin{tabular}{r|r} 
& \\
10 & \\
10 & 10 \\
28 & 20 \\
10 & 48 \\
8 & 58 \\
10 & 66 \\
10 & 76 \\
12 & 86 \\
2 & 98 \\
6 & 100 \\
20 & 106 \\
4 & 126 \\
10 & 130 \\
10 & 140 \\
5 & 150 \\
10 & 155 \\
10 & 165 \\
6 & 175 \\
10 & 181 \\
20 & 191 \\
3 & 211 \\
6 & 214 \\
11 & 220 \\
2 & 231 \\
2 & 233 \\
10 & 235 \\
1 & 245 \\
2 & 246 \\
2 & 248 \\
& 250 \\
& \\
& \\
&
\end{tabular}


TABLE 13.-Water-level measurements in selected wells in northwestern Nassau and northeastern Queens Counties, N.Y.

[All water levels given in feet above or below mean sea level, Sandy Hook, N.J. datum. Water levels are tape measurements. Location of wells shown on pl, i]

\begin{tabular}{l|l|l|l||c|c}
\hline Date & $\begin{array}{c}\text { Water } \\
\text { level }\end{array}$ & Date & $\begin{array}{c}\text { Water } \\
\text { level }\end{array}$ & Date & $\begin{array}{c}\text { Water } \\
\text { level }\end{array}$ \\
\hline
\end{tabular}

\section{NASSAU COUNTY}

N24

[Manhasset-Lakeville Water District, Manhasset, N.Y.]

\begin{tabular}{|c|c|c|c|c|c|}
\hline 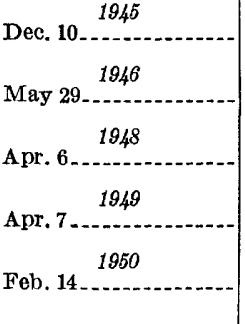 & $\begin{array}{l}6.36 \\
\text { 1. } 94 \\
\text { 4. } 70\end{array}$ & $\begin{array}{l}\text { Mar. 17 } \\
\text { May 1. } 1953 \\
\text { Jan. } 25 \\
\text { Feb. } 7 \\
\text { May } 31 \\
\text { July } 11 \\
\text { Aug. } 1955 \\
\text { Sept. } 30 \\
\text { Nov. } 4\end{array}$ & $\begin{array}{r}-1.42 \\
-1.52 \\
\\
9.92 \\
11.25 \\
-3.08 \\
-11.90 \\
-2.77 \\
.00 \\
1.76\end{array}$ & $\begin{array}{l}\text { Jan. } 5 \\
\text { Feb. 1 } 1956 \\
\text { Feb. } 27 \\
\text { June } 1 \\
\text { July } 17 \\
\text { Aug. } 7 \\
\text { Oct. 2 } \\
\text { Nov. } 5 \\
\text { Jan. } 4 \\
\text { Feb. } 4 \\
\text { Mar. } 29 \\
\text { July } 5\end{array}$ & $\begin{array}{r}6.52 \\
6.00 \\
8.20 \\
4.18 \\
4.30 \\
-2.47 \\
1.20 \\
8.03 \\
\\
6.97 \\
9.80 \\
11.02 \\
-5.83\end{array}$ \\
\hline
\end{tabular}

N36

[Village of Sands Point, Sands Point, N.Y.]

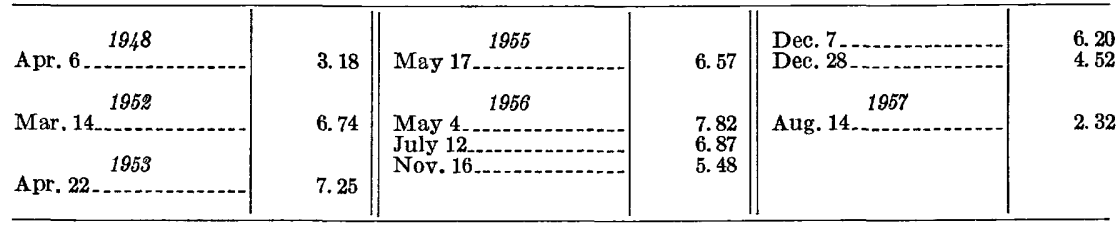

N 110

[Jericho Water District, Glenwood Landing, N.Y.]

\begin{tabular}{|c|c|c|c|c|c|}
\hline 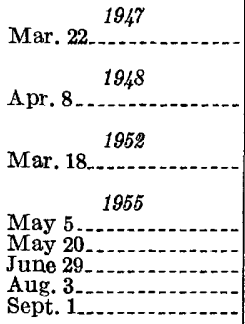 & $\begin{array}{r}11.68 \\
\\
13.51 \\
13.32 \\
11.52 \\
9.49 \\
11.90\end{array}$ & $\begin{array}{l}\text { Sept. } 29 \\
\text { Nov. } 3 \\
\text { Nov. } 30 \\
\text { Dec. } 30 \\
\text { Jan. } 30 \\
\text { Mar. } 1956 \\
\text { Mar. } 30 \\
\text { Apr. } 30 \\
\text { May } 31 \\
\text { July } 1 \\
\text { July } 31 \\
\text { Aug. } 31 \\
\text { Oct. } 1\end{array}$ & $\begin{array}{r} \\
15.53 \\
14.69 \\
15.62 \\
15.68 \\
14.44 \\
.53 \\
13.03 \\
11.60 \\
12.87\end{array}$ & $\begin{array}{l}\text { Nov. } 30 \\
\text { Dec. } 31 \\
\text { Feb. } 1 \text {. } 1957 \\
\text { Mar. } 4 \\
\text { Apr. } 1 \\
\text { May } 1 \\
\text { May } 31 \\
\text { July } 1 \\
\text { Aug. } 1 \\
\text { Aug. } 30 \\
\text { Oct. } 3 \\
\text { Oet. } 30\end{array}$ & $\begin{array}{r}15.23 \\
16.45 \\
15.60 \\
16.41 \\
15.92 \\
15.98 \\
1.76 \\
6.89 \\
1.24 \\
11.71 \\
13.65 \\
12.63\end{array}$ \\
\hline
\end{tabular}

N675

Board of Sewer Commissioners, Port Washington, N.Y.]

\begin{tabular}{|c|c|c|c|c|c|}
\hline $\begin{array}{l}\text { Apr. } 17 \\
\text { July } 11 \\
\text { Sept. } 14 \\
\text { Oct. } 3 . \\
\text { Oct. } 956 \\
\text { Oct. } 15\end{array}$ & $\begin{array}{r}1.06 \\
-1.38 \\
1.64 \\
-.37 \\
3.09 \\
2.07\end{array}$ & $\begin{array}{l}\text { Oct. } 15 \\
\text { Nov. } 2 \\
\text { Nov. } 27 \\
\text { Nov. } 28 \\
\text { Feb. } 5\end{array}$ & $\begin{array}{r}-.08 \\
6.87 \\
6.72 \\
2.55 \\
\\
3.45\end{array}$ & $\begin{array}{l}\text { Apr. 26 } \\
\text { July } 5 \\
\text { July } 18 \\
\text { Jan. } 30 .\end{array}$ & $\begin{array}{r}1.86 \\
-5.74 \\
-3.80 \\
7.02\end{array}$ \\
\hline
\end{tabular}


TABLE 13.-Water-level measurements in selected wells in northwestern Nassau and northeastern Queens Counties, N.Y.-Continued

\begin{tabular}{|c|c|c|c|c|c|}
\hline Date & $\begin{array}{l}\text { Water } \\
\text { level }\end{array}$ & Date & $\begin{array}{l}\text { Water } \\
\text { level }\end{array}$ & Date & $\begin{array}{l}\text { Water } \\
\text { level }\end{array}$ \\
\hline
\end{tabular}

N1328

[Manhasset-Lakeville Water District, North Hills, N.Y.]

\begin{tabular}{|c|c|c|c|c|c|}
\hline $\begin{array}{l}\text { May 29 } 1946 \\
\text { Dec. 29 } 1949 \\
\text { Mar. 17 } \\
\text { Mar. 2 } 1959 \\
\text { Aug. } 7 \\
\text { Dec. 2 }\end{array}$ & $\begin{array}{r}3.21 \\
\\
5.08 \\
-2.34 \\
4.92\end{array}$ & $\begin{array}{l}\text { Jan. } 31 \\
\text { Mar. 14 } \\
\text { Apr. } 22 \\
\text { May } 31 \\
\text { July } 11 \\
\text { Aug. } 1955 \\
\text { Oct. } 3 \\
\text { Nov. } 19 \\
\text { Dec. } 5 \\
\text { Jan. } 5\end{array}$ & $\begin{array}{r}12.53 \\
16.18 \\
13.85 \\
.50 \\
-4.68 \\
-.61 \\
-1.43 \\
7.36 \\
6.96\end{array}$ & $\begin{array}{l}\text { Feb. 27 } \\
\text { Apr. } 4 \\
\text { June } 6 \\
\text { July 17 } \\
\text { Aug. 24 } \\
\text { Nov. } 5 \\
\text { Jan. } 4 \\
\text { Feb. } 4 \\
\text { Mar. 29 } \\
\text { May } 7\end{array}$ & $\begin{array}{r}10.99 \\
8.80 \\
8.79 \\
.06 \\
4.47 \\
11.06 \\
\\
9.46 \\
12.51 \\
13.46 \\
8.71\end{array}$ \\
\hline
\end{tabular}

N1482

[Nassau County Department of Public Works, Port Washington, N.Y.

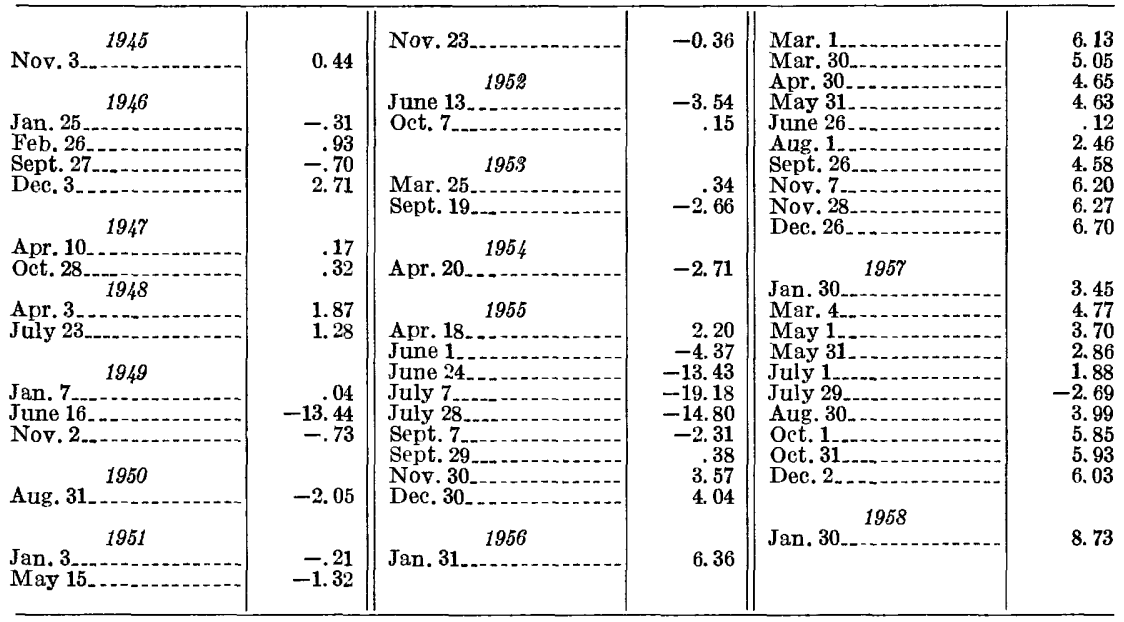

N1715

[Port Washington Water District, Port Washington, N.Y.]

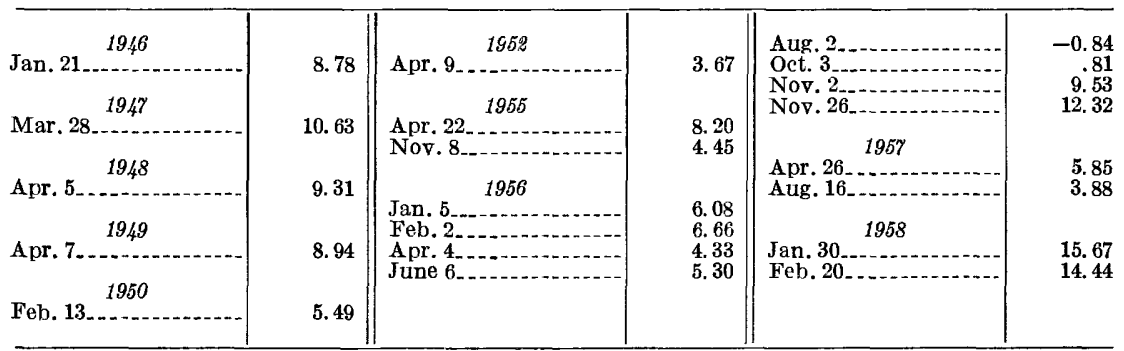


84 HYDROGEOLOGY OF NASSAU AND QUEENS COUNTIES, N.Y.

TABLE 13.-Water-level measurements in selected wells in northwestern Nassau and northeastern Queens Counties, N.Y.-Continued

\begin{tabular}{|c|c|c|c|c|c|}
\hline Date & $\begin{array}{l}\text { Water } \\
\text { level }\end{array}$ & Date & $\begin{array}{l}\text { Water } \\
\text { level }\end{array}$ & Date & $\begin{array}{l}\text { Water } \\
\text { level }\end{array}$ \\
\hline
\end{tabular}

N6282

[U.8. Geol. Survey, Sands Point, N.Y.]

\begin{tabular}{|c|c|c|c|c|c|}
\hline $\begin{array}{l}\text { Aug. 29. } 1957 \\
\text { Sept. 26. } \\
\text { Oet. 31 } \\
\text { Dec. } 2 \\
\text { Dec. } 31\end{array}$ & $\begin{array}{l}6.46 \\
7.02 \\
7.35 \\
7.27 \\
7.49\end{array}$ & $\begin{array}{l}\text { Jan. 29. } 1958 \\
\text { Feb. 28 } \\
\text { Mar. 31. } \\
\text { Apr. 30. } \\
\text { May 28. } \\
\text { June 27 }\end{array}$ & $\begin{array}{l}8.59 \\
8.98 \\
8.91 \\
9.10 \\
9.54 \\
9.12\end{array}$ & $\begin{array}{l}\text { July } 28 \\
\text { Aug. } 29 \\
\text { Sept. } 29 \\
\text { Oct. } 29 \\
\text { Dec. } 2 \\
\text { Dec. } 30 \\
\end{array}$ & $\begin{array}{l}8.13 \\
7.91 \\
8.10 \\
8.65 \\
8.10 \\
8.00\end{array}$ \\
\hline
\end{tabular}

N6291

[U.S. Geol. Survey, Port Washington, N.Y., (N-2269 at same site)]

\begin{tabular}{|c|c|c|c|c|c|}
\hline $\begin{array}{l}\text { June } 28.1857 \\
\text { July } 18 . \\
\text { Sept. } 5\end{array}$ & $\begin{array}{l}96.70 \\
96.99 \\
96.15\end{array}$ & $\begin{array}{c}1958 \\
\text { Jan. } 30.12\end{array}$ & $\begin{array}{l}95.80 \\
95.91\end{array}$ & $\begin{array}{c}\text { Feb. } 28 . \ldots \\
\text { Jan. } 9\end{array}$ & $\begin{array}{l}96.29 \\
97.12\end{array}$ \\
\hline
\end{tabular}

\section{QUEENS COUNTY}

Q276

[New York City Department of Water Supply, Gas and Electricity, Douglaston, N.X.]

\begin{tabular}{|c|c|c|c|c|c|}
\hline $\begin{array}{l}\text { Jan. 14 } 1955 \\
\text { Mar. } 31 \\
\text { Nov. } 1 \\
\end{array}$ & $\begin{array}{l}23.60 \\
23.66 \\
24.25\end{array}$ & Jan. 28. & 24.94 & $\begin{array}{l}\text { Aug. } \\
1957\end{array}$ & Well flled with concrete. \\
\hline
\end{tabular}

Q1603D

[Glen Oaks shopping Center, Glen Oaks, N.Y.]

\begin{tabular}{|c|c|c|c|c|c|}
\hline $\begin{array}{l}\text { Juy } 14.1950 \\
\text { Dec. 6- }\end{array}$ & $\begin{array}{l}53.92 \\
53.00\end{array}$ & $\begin{array}{c}1952 \\
\text { Jan 3. } \\
\text { Jan. 14 } \\
\end{array}$ & $\begin{array}{l}53.37 \\
55.63\end{array}$ & $\begin{array}{c}1957 \\
\text { Apr. } 22 . \\
-\end{array}$ & 51.65 \\
\hline
\end{tabular}




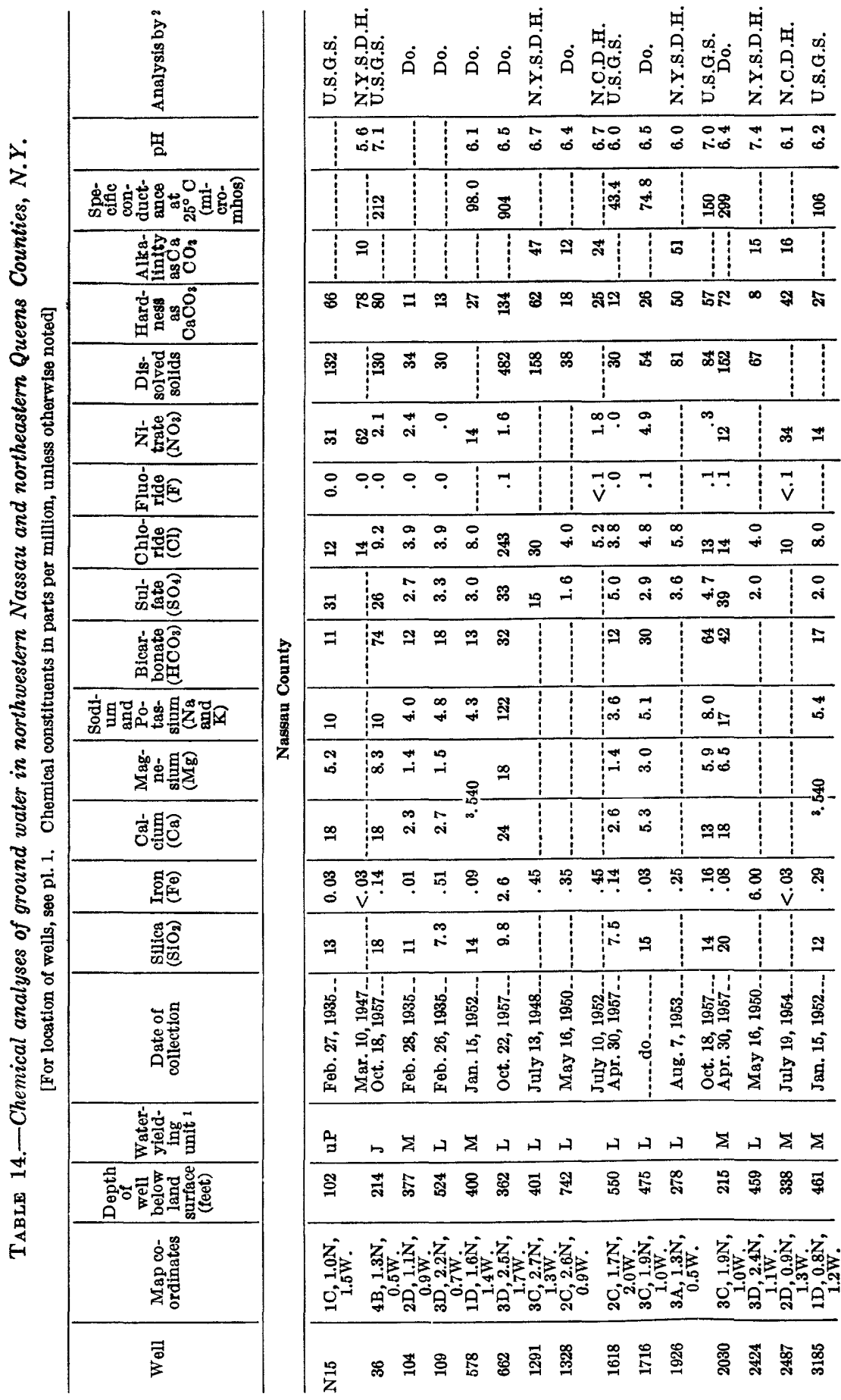




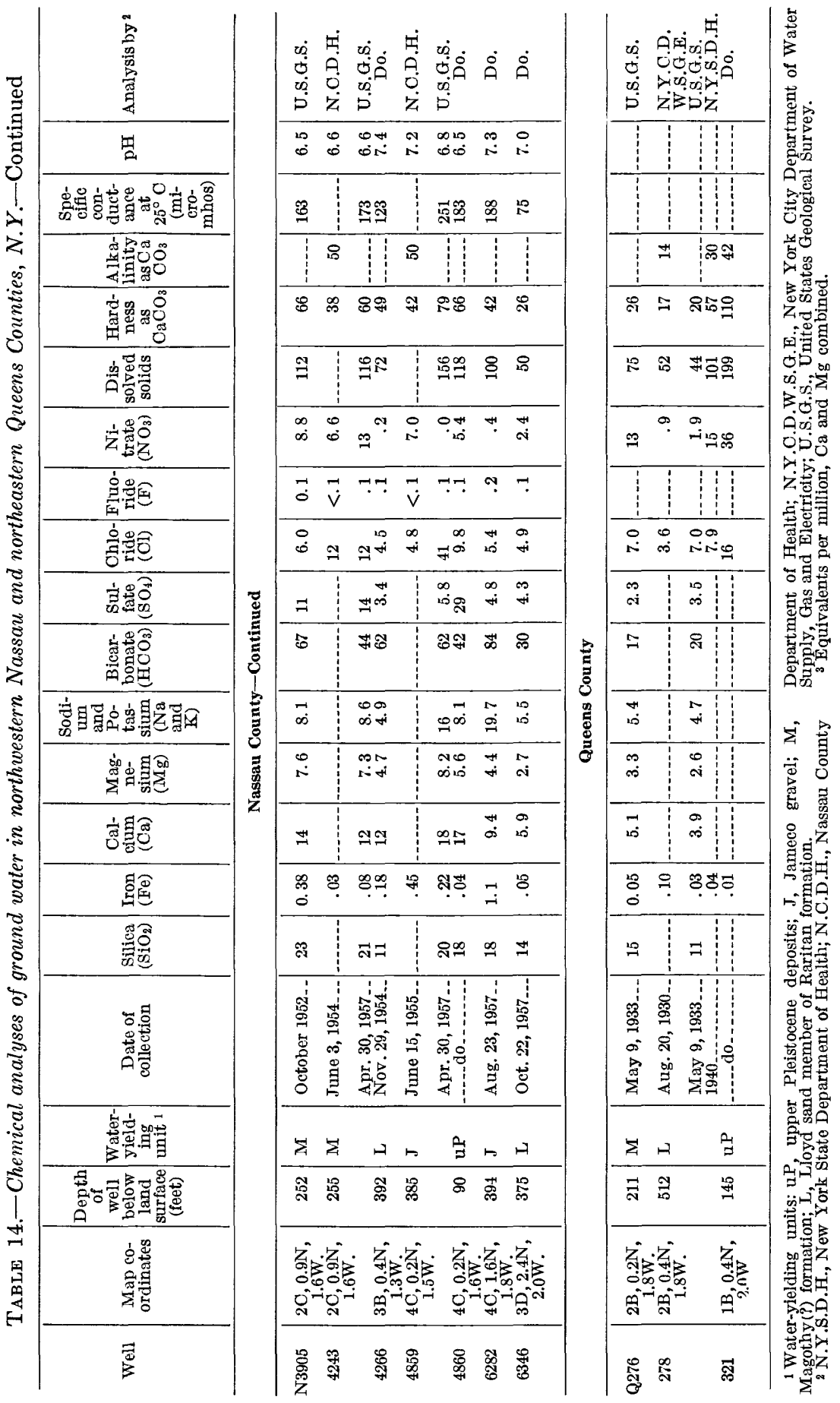


TABLE 15.-Chloride analyses of water from selected wells in northwestern Nassau County, N.Y.

[Location of wells shown on pl. 1]

\begin{tabular}{|c|c|c|c|c|c|}
\hline Date & $\begin{array}{c}\text { Chloride } \\
\text { (ppm) }\end{array}$ & Date & $\begin{array}{c}\text { Chloride } \\
\text { (ppm) }\end{array}$ & Date & $\begin{array}{c}\text { Chloride } \\
\text { (ppm) }\end{array}$ \\
\hline
\end{tabular}

N35

[Port Washington Water District, Port Washington, N.Y.]

\begin{tabular}{|c|c|c|c|c|c|}
\hline $\begin{array}{l}1944 \\
\text { July } 18 \\
\text { Aug. 19. }\end{array}$ & $\begin{array}{l}700 \\
910\end{array}$ & $\begin{array}{c}1945 \\
\text { Oet. } 9 \\
\text { Jan. } 15.46\end{array}$ & $\begin{array}{l}1,000 \\
1,150\end{array}$ & Aug. 30 1957 & 540 \\
\hline
\end{tabular}

N657

[Town of North Hempstead, Bar Beach, Port Washington, N.Y.]

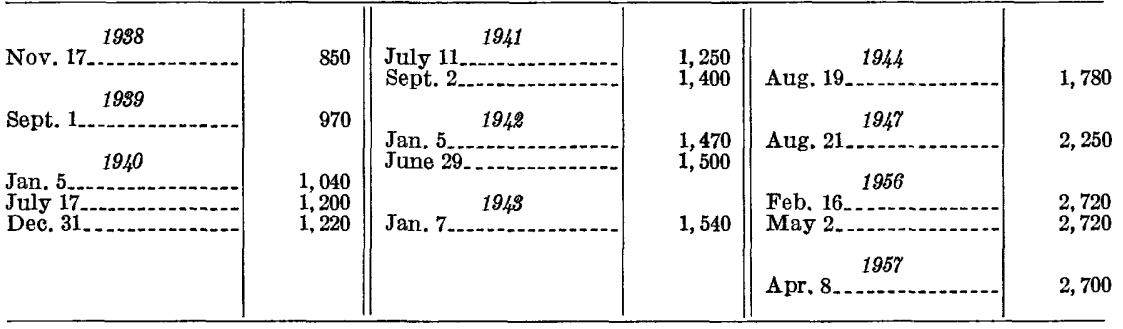

N662

[Town of North Hempstead, Bar Beach, Port Washington, N.Y.]

\begin{tabular}{|c|c|c|c|c|c|}
\hline 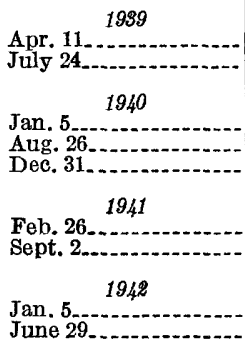 & $\begin{array}{r}70 \\
165 \\
\\
17 \\
220 \\
32 \\
\\
6.0 \\
214\end{array}$ & $\begin{array}{l}\text { Jan. } 7 \\
\text { July } 30 \\
\text { Aug. 19.1944 } \\
\text { Mar. 26 } 1945 \\
\text { Sept. 17 } 1946 \\
\text { Aug. 21. } 1947\end{array}$ & $\begin{array}{l}264 \\
322 \\
290\end{array}$ & $\begin{array}{l}\text { Oct. } 21 \\
\text { Feb. } 16 \\
\text { Apr. } 17 \\
\text { July } 5 \\
\text { Nov. } 14 \\
\text { Feb. } 7 \\
\text { Mar. } 1556 \\
\text { Apr, } 8 \\
\text { June } 14 \\
\text { Oct. } 22\end{array}$ & $\begin{array}{l}340 \\
360 \\
370 \\
370 \\
243\end{array}$ \\
\hline
\end{tabular}

$\mathbf{N 6 7 5}$

[Board of Sewer Commissioners, Port Washington, N.Y.]

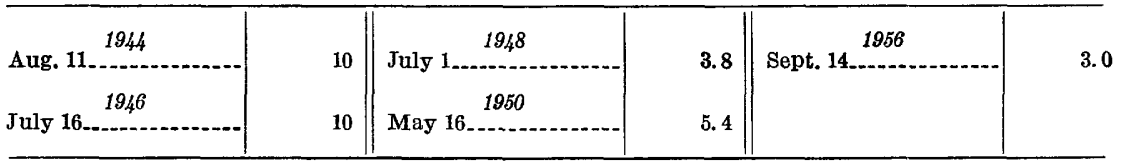

N906

[Sea Cliff Water Company, Sea Cliff, N.Y.]

\begin{tabular}{|c|c|c|c|c|c|}
\hline $\begin{array}{l}\text { Jan. 19. } 1989 \\
\text { Mar. 29 } \\
\text { Dec. } 5\end{array}$ & $\begin{array}{r}4.0 \\
5.0\end{array}$ & $\begin{array}{l}\text { Apr. } 11 \\
\text { Oct. } 1040 \\
\text { Oct. } 27 \\
1942\end{array}$ & $\begin{array}{c}5.0 \\
10\end{array}$ & $\begin{array}{l}\text { Mar. 26. } 1945 \\
\text { July 18. } 1946 \\
\text { Jan. 17 } 1949\end{array}$ & $\begin{array}{l}8.0 \\
15 \\
4.0\end{array}$ \\
\hline
\end{tabular}


TABLE 15.-Chloride analyses of water from selected wells in northwestern Nassau County, N.Y.-Continued

\begin{tabular}{l|l|l|l|l|}
\hline Date & $\begin{array}{c}\text { Chloride } \\
(\mathrm{ppm})\end{array}$ & Date & $\begin{array}{c}\text { Chloride } \\
(\mathrm{ppm})\end{array}$
\end{tabular} \mid Date $\mid \begin{gathered}\text { Chloride } \\
(\mathrm{ppm})\end{gathered}$

\section{N1482}

[Nassau County Department of Public Works, Port Washington, N.Y.]

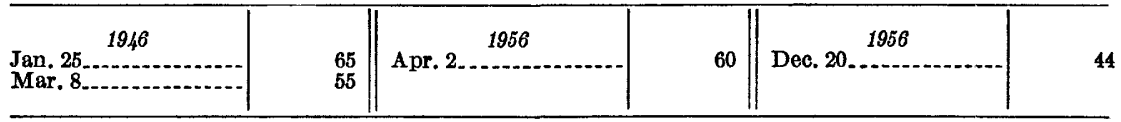

\section{N1483}

[Nassau County Department of Public Works, Port Washington, N.Y.]

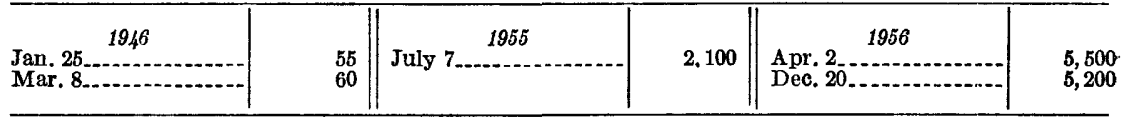

N1484

[Nassau County Department of Public Works, Port Washington, N.Y.]

\begin{tabular}{|c|c|c|c|c|c|}
\hline $\begin{array}{l}1946 \\
\text { Jan. 25 } \\
\text { Mar. } 8 \\
\end{array}$ & $\begin{array}{l}115 \\
145\end{array}$ & July 7 & 88 & $\begin{array}{l}1956 \\
\text { Apr. } 2 \\
\text { Oct. } 3 \\
\text { Dec. } 20\end{array}$ & $\begin{array}{r}104 \\
90 \\
96\end{array}$ \\
\hline
\end{tabular}

\section{N1716}

[Port Washington Water District, Port Washington, N.Y.]

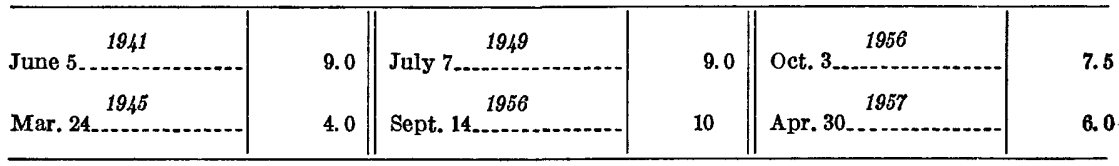

N2424

[Long Island Lighting Company, Glenwood Landing, N.Y.]

\begin{tabular}{ll}
\hline July $7 . \ldots 49$ \\
\hline
\end{tabular}

N3311

[Colonial Sand and Stone Company, Port Washington, N.Y.]

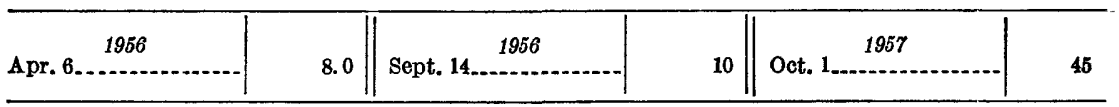

\section{N4859}

[Port Washington Water District, Port Washington, N.Y.]

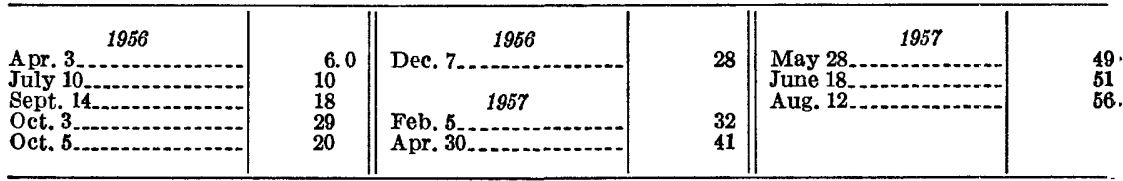




\section{N D EX}

[Where several page numbers appear, major references are in italic]

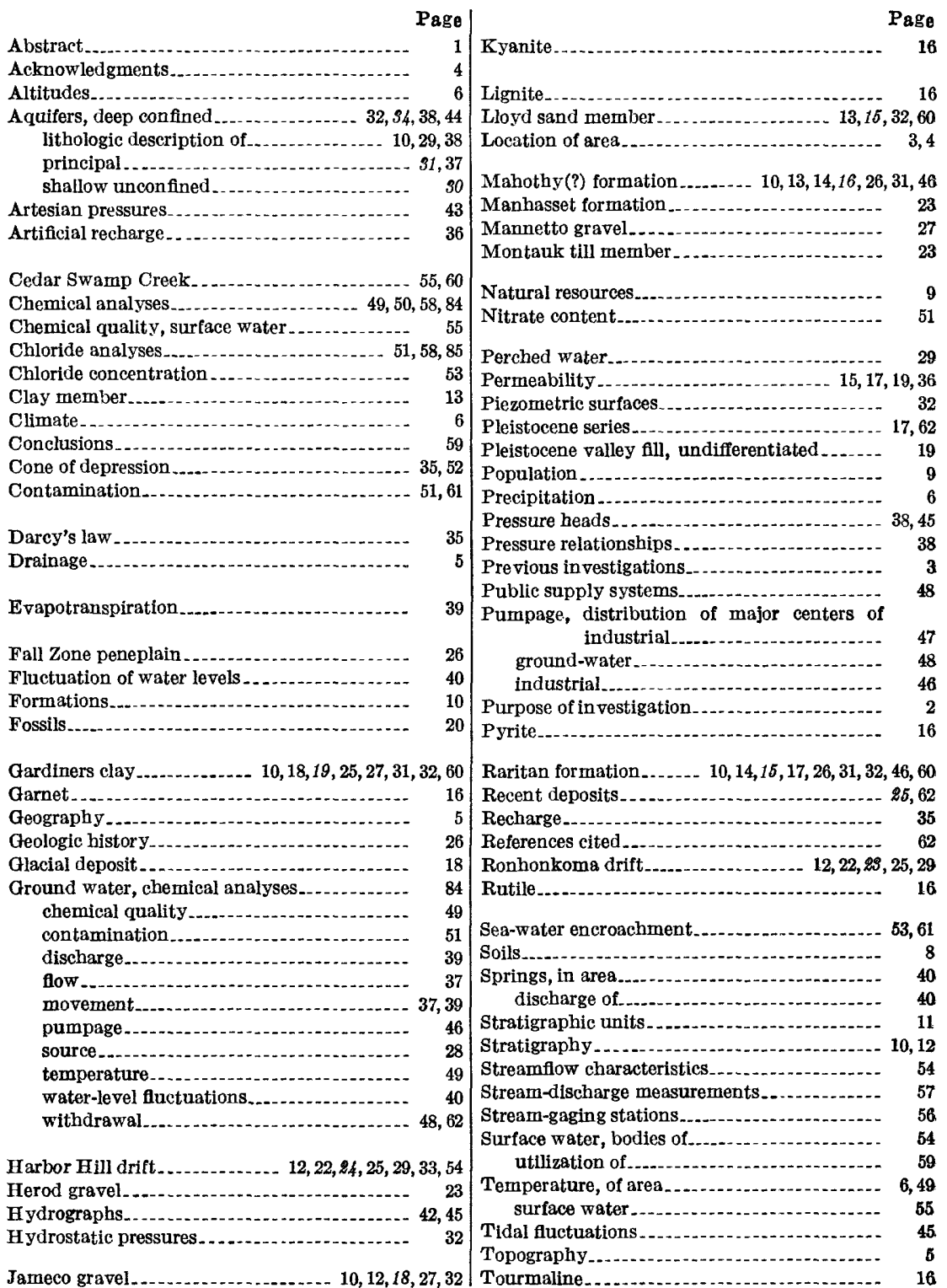


Undifferentiated deposits of Pleistocene age.

Upper Pleistocene deposits.
Utilization of surface water.

18

Water-bearing properties-Continued

Page undifferentiated deposits.................. 18

(1)

Vegetation

Uppe1 Cretaceous series

Water-level measurement..................... 82

8 Water-level record.............................. 44

Water table . .

Water-bearing properties, clay member.......

15 Well-numbering system.................. 5

Jameco gravel

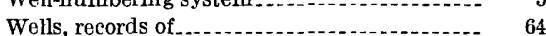

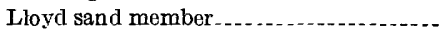

Magothy(?) formation

Precambrian bedrock

Zircon

Raritan formation

10 Zone of saturation. 